\title{
MASTER
}

\section{Assessment of Radiological Impact of the Inactive Uranium-Mill Tailings Pile at Salt Lake City, Utah}

\author{
F. F. Haywood \\ W. A. Goldsmith \\ P. T. Perdue \\ W. F. Fox \\ W. H. Shinpaugh
}

OAK RIDGE NATIONAL LABORATORY OPERATED BY UNION CARBIDE CORPORATION - FOR THE DEPARTMENT OF ENERGY 


\section{DISCLAIMER}

This report was prepared as an account of work sponsored by an agency of the United States Government. Neither the United States Government nor any agency Thereof, nor any of their employees, makes any warranty, express or implied, or assumes any legal liability or responsibility for the accuracy, completeness, or usefulness of any information, apparatus, product, or process disclosed, or represents that its use would not infringe privately owned rights. Reference herein to any specific commercial product, process, or service by trade name, trademark, manufacturer, or otherwise does not necessarily constitute or imply its endorsement, recommendation, or favoring by the United States Government or any agency thereof. The views and opinions of authors expressed herein do not necessarily state or reflect those of the United States Government or any agency thereof. 


\section{DISCLAIMER}

Portions of this document may be illegible in electronic image products. Images are produced from the best available original document. 


\begin{tabular}{|c|}
\hline Printed in the United States of America. Available from \\
National Technical Information Service \\
U.S. Department of Commerce \\
5285 Port Royal Road, Springfield, Virginia 22161 \\
Price: Printed Copy $\$ 6.50$; Microfiche $\$ 3.00$ \\
\hline
\end{tabular}

This report was prepared as an account of work sponsored by an agency of the United States Government. Neither the United States Government nor any agency thereof, nor any of their employees, contractors, subcontractors, or their employees, makes any warranty, express or implied, nor assumes any legal liability or responsibility for any third party's use or the results of such use of any information, apparatus, product or process disclosed in this report, nor represents that its use by such third party would not infringe privately owned rights. 
ORNL/TM-5251

Dist. Category UC -41

(i)

Contract No. W-7405-eng-26

HEALTH AND SAFETY RESEARCH DIVISION

ASSESSMENT OF RADIOLOGICAL IMPACT OF THE INACTIVE

URANIUM-MILL TAILINGS PILE AT SALT LAKE CITY, UTAH

F. F. Haywood, W. A. Goldsmith, P. T. Perdue,

W. F. Fox, and W. H. Shinpaugh

This report was prepared as an account of work sponsored by the United States Government. Neither the United States nor the United States Department of Energs, nor any of their employees, nor any of their contractors, subcontractors, or their employees, makes any warranty, express or implied, nr astumes any legal

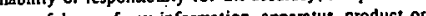
or userulness of any information, appas would not process disclosed, or iepresents ing ils use would not infringe privately owned rights.

Prepared by the

OAK RIDGE NATIONAL LABORATORY

Oak Ridge, Tennessee

operated by

UNION CARBIDE CORPORATION

for the

DEPARTMENT OF ENERGY

$\xi b$

DISTRABUTION OF THIS DOCUMENT IS UNLHMITED 
THIS PAGE

\section{WAS INTENTIONALLY \\ LEFT BLANK}




\section{CONTENTS}

Page

LIST OF ILLUSTRATIONS. . . . . . . . . . . . . . . . v

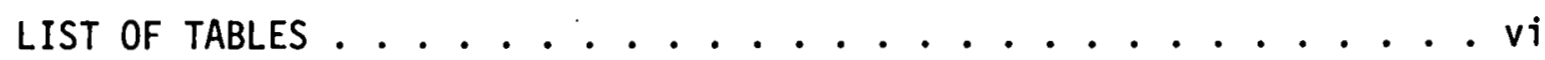

ACKNOWLEDGMENTS. ................................ . . . . . .

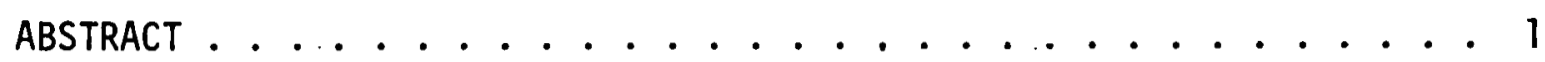

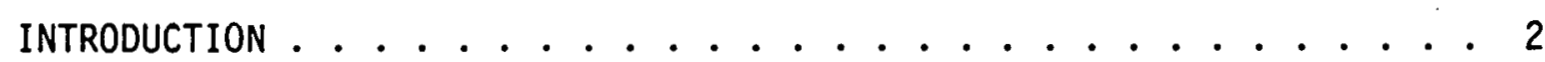

BACKGROUND AND OBJECTIVES. . . . . . . . . . . . 5

Scope of Work . . . . . . . . . . . . . . . 9

BEHAVIOR OF TAILINGS PILE RADIONUCLIDES. . . . . . . . . . 11

Radon Diffusion Pathway .............. . 11

Airborne Activity Pathway . . . . . . . . . . . . 20

Terrestrial Pathway. . . . . . . . . . . . . 22

Aquatic Pathway ................. . . 23

External Gamma Radiation. . . . . . . . . . . 25

RADIOLOGICAL MEASUREMENTS AND TECHNIQUES . . . . . . . . 27

Radionuclide Concentration as a Function of Depth in Soil . . . 27

Field Laboratory Facilities and Equipment . . . . . . . . . 31

Gamma Spectroscopy Systems. . . . . . . . . . . . 34

External Gamma-Ray Detector . . . . . . . . . . 37

Radon Daughter Sampler. . . . . . . . . . . 38

Radon Monitor . . . . . . . . . . . . 40

EXPERIMENTAL RESULTS . . . . . . . . . . . . 42

Background Radionuclide Concentrations. . . . . . . . . 42

Radioactivity in Groundwater in Tailings Pile ....... . 49

Radionuclide Concentrations on the Site........51 
CONTENTS (continued)

Page

Radionuclide Concentrations off the Site........ 53

Elemental Composition of Material from the Vitro Tailings Pile . 59

Direct Gamma-Ray Exposure Rates On and Near the Tailings Pile. . 59

Radon and Radon Daughter Concentration in Structures . . . . 62

Calculation of ${ }^{222}$ Rn Emanation and Dispersion from the

Tállings Pile................. 65

Concentrations of Airborne Radionuclides . . . . . . . . 69

HEALTH EFFECTS ATTRIBUTABLE TU IHE VITRO TAILINGS PILE. . ... . ... 74

Radon Diffusion Pathway. ............ . 74

Exposure to Gamma Radiation. . . . . . . . . . . . 82

Health Effects Attributable to Other Pathways. . . . . . . 84

SUMMARY AND CONCLUSIONS ............... 85 


\section{LIST OF ILLUSTRATIONS}

Figure

1 Aerial view of Vitro mill site, tailings piles, and surrounding area. . . . . . . . . . . . . . . . 7

2 Graphic representation of radon emanation from wet, moist, and dry tailings as a function of ${ }^{226} \mathrm{Ra}$ concentration and depth of tailings ................... . . 18

3 View of horizontal $\mathrm{Ge}(\mathrm{Li})$ detector and sample "carousel" holder used for gamma-ray spectroscopy. . . . . . . . . 30

4. Plan view of the Vitro mill site showing core hole and offsite sample locations. . . . . . . . . . . . 32

5 Plan view of the Vitro mill site showing location of water samples collected in surface streams. . . . . . . 33

$6 \mathrm{Ge}(\mathrm{Li})$ detector and lead shield arrangement used for counting soil and sediment samples. . . . . . . . . . 36

7 Exploded view of system used to count radon daughters collected on filters, showing silicon detector, housing and sample tray .................. 39

8 Map of Salt Lake Valley showing location of background

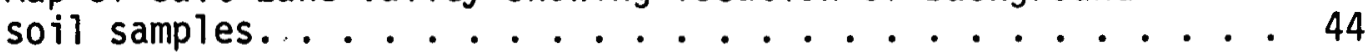

9 Plan view of Vitro mill site showing location of water samples from private wells. . . . . . . . . . . . .

10 Typical profile of ${ }^{226} \mathrm{Ra}$ concentration as a function of depth below the surface of Vitro tailings . . . . . . . . . 52

11 Plot of southwest ared of tailings pile showing the location of commercial structures along 900 West Street and the location of sampling points in these buildings. . . . .

12 External gamma radiation $(\mu \mathrm{R} / \mathrm{hr})$ as a function of distance from the center of the Vitro tailings pile......... 61

13 Map of Salt Lake Valley showing area included in calculations of radon dispersion.............. . 71 


\section{LIST OF TABLES}

Page

1 Principal tailings pile radionuclides. . . . . . . . 12

2 Principal radionuclides involved in pathways from tailings piles to man................... 13

3 Background radionuclide concentrations in soil samples in the Salt Lake Valley.................. . 45

4 Radionuclide concentrations in well water near the Vitro site, Salt Lake City, Utah.................... 48

5 Radlumuclide concentration in compusite sample from groundwater in the Vitro tailings pile............... . 40

6. 226 Ra concentration in soil collected off llie sitc in areas surrounding the Vitro pile............... . 54

7 Radionuclide concentration in sediment samples . . . . . . . 46

$8 \quad 226 \mathrm{Ra}$ concentration in soil beneath the floor of commercial structures along southwest edge of Vitro tailings pile... . 58

9 Elemental composition of material from the Vitro tailings pile........................ 60

10 Gamma-ray exposure rates inside commercial structures along southwesl edge of vitro tailings pile. .......... 63

11 Concentration of radon and radon daughters . . . . . . . . . 64

12 Determination of average ${ }^{226} \mathrm{Ra}$ concentration of Vitro tailings pile..................... 66

$13 \quad 222 \mathrm{Rn}$ concentration ( $\mathrm{pC} / / \mathrm{liter}$ ) resulting from the Vitro tailings pile...................... ... 68

14 Comparison of calculated and measured $222 \mathrm{Rn}$ concentrations in Salt Laké City. . ................. . 70

15 Average concentrations of airborne radionuclides at Suburban Sewage Treatment Plant, Salt Lake City, Utah . . . . . . .

16 Summary of ${ }^{222} \mathrm{Rn}$ exposures attributable to Vitro tallings

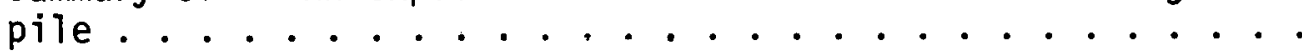




\section{LIST OF TABLES (CONTINUED)}

Page

17 Extrapolated ${ }^{22} \mathrm{Rn}$ exposures attributable to Vitro tailings pile for medium density population projection. . . . . . . . . 78

18 Extrapolated ${ }^{22} \mathrm{Rn}$ exposures attributable to Vitro tailings pile for high density population projection. . . . . . . . . 79

19 A comparison of potential health effects attributable to ${ }_{22}^{2} \mathrm{Rn}$ progeny exposure from the Vitro tailings pile and from background for the population residing continuously within 7 miles of the vitro tailings plle............

20. Potential health effects attributable to external gamma irradiation resulting from the Vitro tailings pile....... 


\section{ACKNOWLEDGMENTS}

The authors wish to express their appreciation to L. Joe Deal, Division of Operational and Environmental Safety, Department of Energy, and R. H. Kennedy, Division of Environmental Control Technology, Department of Energy, for their support and encouragement throughout the course of this work. Also, the authors would like to acknowledge the awareness of these men to the broad range of problems posed by unattended tailings piles. Thanks go to the following people at the Oak Ridge National Laboratory for their valuable discussions and assistance in planning, making equipment and facilities field ready, sample analysis, data handling, and report preparation: J. A. Auxier, D. G. Jacobs, J. H. Thorngate, H. W. Dickson, L. C. Henley, J. F. Emery, C. P. Littleton, D. J. Christian, M. Sears, S. Larkins, Jo Brown, E. T. Loy, Anne Webb, Mary Davis, Barbara Davis, and Sally Stockstill. William McKinney and his staff, Bureau of Mines, Salt Lake City, offered valuable advice and assistance in the handling of soil samples. Bureau of Mines facilities were made available for drying and grinding of soil. This cooperation is gratefully acknowledged. The field work in this project was done in cooperation with the engineering firm Ford, Bacon and Davis, Utah, of Salt Lake City, Utah. Thanks are extended to Gary Gantner and Vern Rogers and their respective staffs for assistance rendered in obtaining samples and for valuable liaison with property owners. Important discussions were held with R. C. Pendleton, University of Utah, and L. R. Anspaugh, Lawrence Livermore Laboratory, with regard to previous studies of the natural radiation environment in the Salt Lake Valley and across the state of Utah; and results of many of their measurements were made available for comparison. Appreciation is extended to the EPA for its support of this study and to Don Hendricks and his staff (EPA, Las Vegas) for valuable discussions pertaining to the many measurements made by EPA staff at the Salt Lake City site. The authors wish to extend their sincere appreciation to $F$. A. Gifford and Walter M. Culkowski of the Atmospheric Turbulence and Diffusion Laboratory, NOAA, Oak Ridge, for their valuable assistance in the adaptation of an atmospheric and diffusion model to the problem of radon transport from tailings piles. Lastly, thanks go to Phil Walsh, ORNL, for a comprehensive technical review of the manuscript and for his useful suggestions. 


\title{
ASSESSMENT OF RADIOLOGICAL IMPACT OF THE INACTIVE
}

\author{
URANIUM MILL TAILINGS PILE AT SALT LAKE CITY, UTAH
}

F. F. Haywood, W. A. Goldsmith, P. T. Perdue, W. F. Fox, and W. H. Shinpaugh

\begin{abstract}
One of the largest inactive uranium mill tailings piles in the United States is located within metropolitan Salt Lake City, Utah. A radiological survey was performed at this site during the fall of 1975 . A series of field and laboratory analyses were performed to characterize the spread of contamination from the tailings pile to surrounding areas. These analyses provided a basis for discussion of the important pathways for transport of radioactivity to man. Measurements of radionuclide concentrations in soil indicated that radium had migrated up to one meter into soil beneath the tailings. Tailings material was found out to distances of several hundred meters, mostly in the prevailing wind directions. Elevated levels of $226 \mathrm{Ra}, 238 \mathrm{U}, 230 \mathrm{Th}$, and $210 \mathrm{~Pb}$ were found in sediments of streams running through the mill site; but in Jordan River samples, radionuclide concentrations were of the same magnitude as background samples collected in other parts of the Salt Lake Valley. Atmospheric dispersion of radon gas, which emanates from the pile continuously, was calculated using a model developed by w. Culkowski. The area source term for this model was determined from available data on radon emanation from tailings sands. Potential health effects for continuous exposure to radon progeny and external gamma radiation from the pile in its current state were estimated using risk estimators presented in the BEIR report. For the 400,000 residents within $11 \mathrm{~km}(7 \mathrm{mi})$ of the pile, 0.4 cases of lung cancer per year were estimated. For the same population exposed to natural levels of radon progeny, 7.2 cases per year were estimated. Based on the assumption that cancer induction is linear with dose down to the low dose range observed in this study, the mortality rate attributable to all cancers resulting from whole body gamma-ray. exposure of the same population was estimated to be 0.04 deaths per year. The comparable mortality rate due to background gamma radiation was estimated to be 3.6 deaths per year. These potential health effects were extrapolated to medium and high derisity population projections. For lung cancer, the incidence was 3 and 4 cases per year, respectively. The major health risk was inhalation of radon progeny. The contributions of other pathways to potential heal th effects were less than the error associated with the estimates of radon concentration.
\end{abstract}




\section{INTRODUCTION}

The milling of uranium ore produces a uranium-concentrated product called "yellow cake" from an ore feed containing a few tenths of a percent uranium by weight. The processes involved in a milling operation, discussed in detail el sewhere, $(1,2)$ are grinding and crushing, leaching uranium from ore, and recovering the uranium from leach liquor. The leaching step produces a solid waste called tailings that is usually impounded on mill property. Mill tailings consist of uranium-depleted ore, processing chemicals, and process wash water. Practically all uranium daughter radionuclides in the ore appear in the tailings.

Uranium mills have been operating at various locations in the western United States for the past three decades. The average operating lifetime of a uranium mill has been about 12 to 15 years. Consequently, 24 of the older mills have been closed down. These inactive mill sites contain about $20 \%$ of all tailings impounded in the United States.

Frequently mill properties were vacated with little if any attention given to preparation of tailings for long-term storage or disposal.

Tailings are a source of gamma radiation, radon and other airborne contamination, and water contamination. Furthermore, tailings material has been removed by individuals for private use. An uncontrolled inactive tailings pile may be regarded as:

1. A large, highly dispersed, uncontained source of radioactivity

2. An unattended source with minimal restraints to public access 
3. A source which will yield continuous public exposure to radiation for several millenia

4. A source of waste-process chemicals and toxic elements continued in the discarded ore matrix.

Since tailings piles represent a public nuisance and potential radiological hazard, one of two approaches could be taken to reduce or minimize impacts of piles: in situ stabilization or removal to a site better suited for long-term management.

The inactive uranium mill in Salt Lake City, Utah, was formerly operated by the Vitro Corporation. At this mill site is a tailings pile that contains an inventory of $\sim 1400 \mathrm{Ci}$ of $226 \mathrm{Ra}$ and its daughters spread over an area of $\sim 5 \times 10^{5} \mathrm{~m}^{2}$ (110 acres). The metropolitan area of Salt Lake City and its 400,000 inhabitants are within $11 \mathrm{~km}(7 \mathrm{mi})$ of the site.

This report presents the results of field and laboratory analyses performed in support of a radiological assessment of this inactive mill site. Physical measurements included: (1) the depth of radionuclide contamination of soil underlying the tailings, (2) the concentration of radionuclides in groundwater, (3) the degree of spread of tailings due to wind and water erosion, (4) radon progeny concentrations in structures near the pile, and (5) external radiation levels on the pile, in structures near the pile, and at points of public access along the site perimeter. These results are interpreted to estimate present and extrapolated maximum public radiation exposures.

It is shown in this report that the radon diffusion pathway for exposure to man predominates at all points outside the perimeter of the mill site. If the nature of property development were to change from 
commercial to high density residential at some time in the future, cumulative population exposures would be dependent on the degree of remedial action taken. Remedial action recommendations will be based on the results of this work combined with an engineering study of inactive uranium mills being conducted by the firm of Ford, Bacon and Davis, Utah, of Salt Lake City, Utah. (4) 


\section{BACKGROUND AND OBJECTIVES}

The former Vitro mill was constructed during World War II to produce alumina. Uranium milling operations began at this site in 1951 and continued for 14 years. The mill was then converted to process ferrophos for vanadium recovery. Uranium milling was carried out in Salt Lake City because the abandoned alumina mill was available and the site was convenient to rail transportation.

Two leaching processes were used during the 14 years of uranium milling. The initial operation, from 1951 to 1957, included an acid leach and uranous phosphate precipitation. In 1957, a $20 \%$ increase in production was obtained by a plant expansion and process modification in which a solvent extraction process was substituted for the precipitation step. Then, prior to shutdown in 1968, the vanadium extraction work was carried out for about four years.

Wastes from these processes consisted of the remains of the fine ore particles (tailings), various chemical compounds used during the total separation process, and process water used for washing and for slurry transfer. Tailings represent a significant long-term management problem because this material is nearly equal to the feed ore in quantity and contains most of the uranium daughters which were not extracted with the uranium. Radioactivity contained in the tailings is found in both the sand and slime fractions. The slimes are made up of particles equal to or less than 200 mesh and make up approximately $20 \%$ of the total volume. However, these fine particles contain $80 \%$ or more of the natural 
radioactivity. The concentration of ${ }^{226} \mathrm{Ra}$ in slimes resulting from the processing of western ores may reach $3000 \mathrm{pCi} / \mathrm{g}$, whereas radioactivity in the sands is generally lower by a factor of 10 .

Vanadium tailings cover parts of the waste area. These vanadium tailings, which are low in radium content, serve to retard radon emanation from the underlying uranium tailings. However, this area is not extensive and if the recommended remedial action for this site should be tailings removal, then these vanadiurn tailings would also require moving. A detailed radiation survey. could be used to define the specific nature of the vanadium tailings area.

A sewage treatment plant on property adjacent to the Vitro mill began operation about the same time as the milling operations. Since 1967, sewage sludge from this plant has been pumped routinely onto several sections of the tailings pile to help reduce the quantity of wind blown material.

Figure $l$ is an aerial photo of the site in its present condition. The overall site is approximately square. About three-fourths of the site area is covered by tailings; the original mill and associated structures were located on the remainder. The property is bounded on two sides by heavily traveled streets and highways. Intact rencing exists along 33rd South Street and along 900 West Street. However, no fellcing exists along the access road to the Salt Lake City Suburban Sewage Treatment $\mathrm{Plant}$, nor on the north and east boundaries of the Denver and Rio Grande Western Railroad property-see dashed lines in 


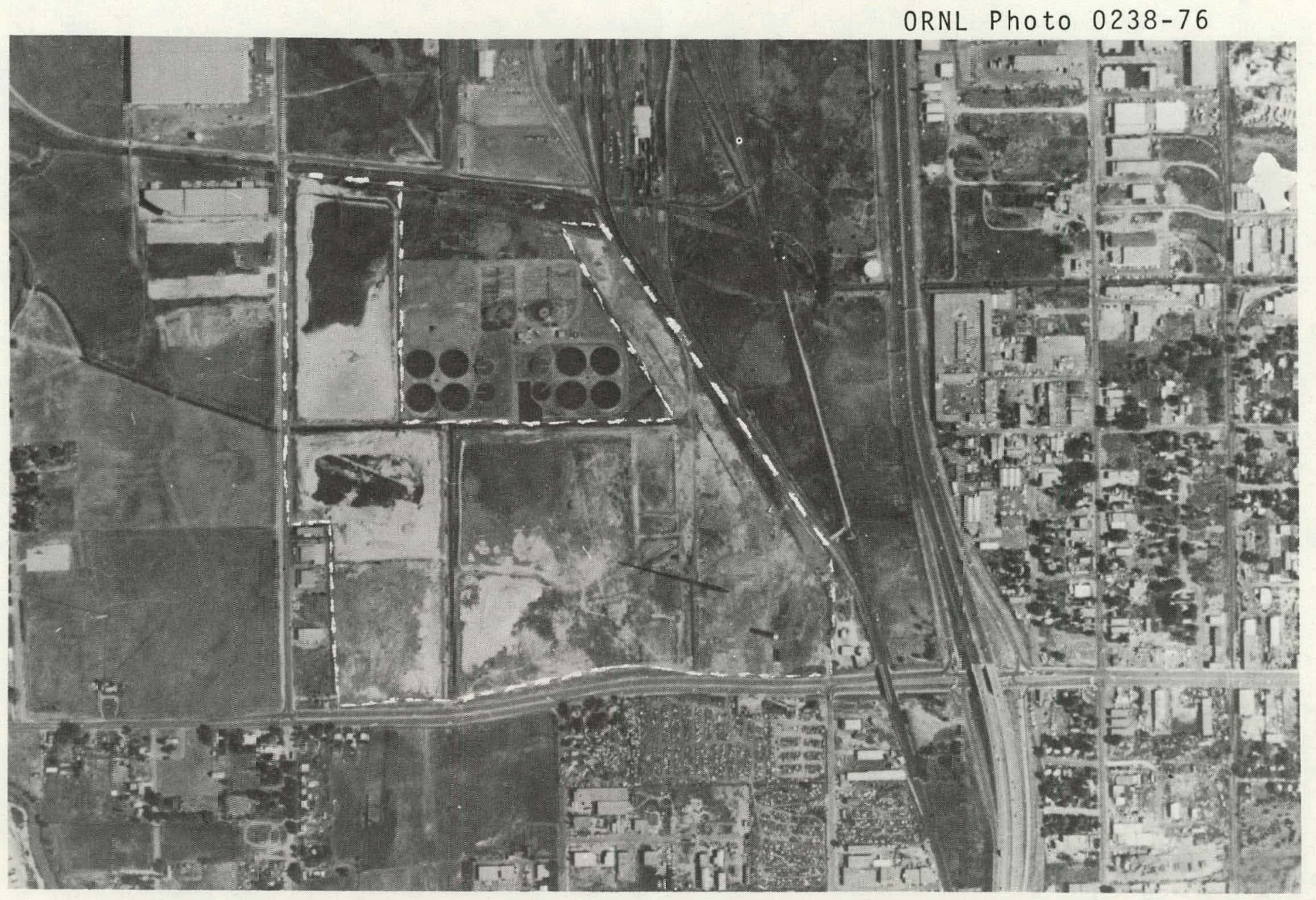

Fig. 1. Aerial view of Vitro mill site, tailings pile, and surrounding area. 
Fig. 1. Therefore, no effective barrier exists to prevent access to the tailings.

The impounded areas grew steadily throughout the years of operation until an area of $4.7 \times 10^{5} \mathrm{~m}^{2}$ ( 2110 acres) was covered with tailings. Although some plant life exists along most of the tailings dikes, no effort toward stabilization has been attempted for the entire site. Therefore, erosion of tailings by wind and rain is not adequately inhibited. One area of about 20 acres was treated experimentally with a chemical stabilizer by the U. S. Bureau of Mines. (5) Some vegetation grows in that location, but this does not eliminate dust blowing during high winds.

In addition to the tailings, a considerable amount of rubble from the dismantled plant is strewn over large areas. Much of this rubble appears to be contaminated with uranium bearing material.

The significance of this abandoned operation on the local area is nol 1 imited to radiological considerations. The mere presence of a restricted site within an otherwise busy commercial and industrial area creates an economic burden on the area. Because the tailings are radioactive, an indefinite ban has been created on construction within approximately a 0.5 mile radius of the site. Presently, there is some discussion about a relaxation on this ban, but there is no clear and well-defined policy on this matter. At present, the trend in property development is commercial; however, no one can predict the situation for this area more than thirty years ${ }^{(4)}$ in the future. Therefore, some degree 
of restriction must be placed on the property as long as it remains in its present condition. This calls for maintenance of access control measures for the foreseeable future.

\section{Scope of Work}

A detailed characterization of the radiological hazards of the Vitro site, as viewed from the standpoint of health effects, is the specific objective of this project. In order to complete such a characterization, it is necessary to do the following:

1. Determine baseline background data on concentration of pertinent radionuclides, such as ${ }^{226} \mathrm{Ra}, 238 \mathrm{U}, 232 \mathrm{Th}, 230 \mathrm{Th}$, and $210 \mathrm{~Pb}$. Numerous samples were collected throughout the Salt Lake Valley.

2. Assess the radiological impact of the tailings pile and associated mill area in its present condition. This entails a detailed study of the radiological variables pertinent to five major radiation dose-to-man pathways.

3. Assess the radiological impact of possible remedial actions. Specific actions which may be taken to reduce, minimize, or eliminate the radiological hazard to the public have been presented in detail elsewhere. (4) These actions include, but are not limited to, erecting strong antipersonnel enclosures, stabilizing the tailings with various thicknesses of earth cover, or removal of tailings to a less populated area. The latter action would return the Vitro site to productive use and remove restrictions against its projected long-term use even for high density residential use. 
In support of 2 above, it was necessary to conduct a series of radiological measurements. The objective of these measurements was to determine the magnitude of radiation levels both on and off site. Of principal concern were ground level air concentrations of radon and progeny in residential and commercial areas and the extent to which tailings had spread to areas surrounding the mill site. These radiation levels were evaluated by making measurements of the radionuclide concentration in samples of soil underlying the tailings, on property adjacent to the mill site, and in samples of surface stream sediments. In addition, water samples were obtained from several private wells, from surface streams, and from each hole which was drilled or dug on the site. Concentrations of radon ( $p C i / l i t e r)$ were measured for continuous 24-hr periods both indoors and outdoors at many locations throughout the Salt Lake Valley by Ford, Bacon and Davis, Utah! Some corresponding measurements were made of the radon progeny concentrations within structures and in outdoor areas. Also, measurements were made of external gamma-ray exposure rates on the pile at locations around the perimeter of the site and at points of interest in the immediate surrounding area.

Radiological measurements made in this study are compared to and supplemented by the results of previous studies in the vicinity of the Vitro mill. These previous studies have yielded data on windblown contamination as well as data on background concentrations of nuclides in soil and air throughout a large area of the Salt Lake Valley and other parts of the state. 


\section{BEHAVIOR OF TAILINGS PILE RADIONUCLIDES}

Milling processes remove about $90 \%$ of the uranium but only a few percent at most of other radionuclides in the original ore. Daughters of ${ }^{238} \mathrm{U}$ contribute about $95 \%$ of tailings activity; the daughters of $235 \mathrm{U}$, about $5 \%$. Differences in geochemical properties of $U$ and Th suggest that ${ }^{232} \mathrm{Th}$ will not be concentrated in postmagmatic minerals containing uranium. ${ }^{(6)}$ Ores commonly mined in the United States contain only thorium isotopes attributable to uranium decay. (2) Tailings which resulted from processing ores older than a few hundred thousand years may contain activities of chain members approaching equilibrium with the original parent uranium activity. A listing of the major uranium and actinium chain members is shown in Table 1.

A recent study by Healy ${ }^{(7)}$ of plutonium soil contamination serves as a good outline of pathways leading to human exposure. A modification of Healy's approach has been applied to tailings pile radionuclides in Table 2. Each of the pathways listed in Table 2 should be evaluated in any assessment of the overall radiological impact of each specific mill site. The factors which influence the pathway processes shown in Table 2 will be evaluated in this chapter.

\section{Radon Diffusion Pathway}

Several generic radiological assessments have been made for inactive uranium mill sites. $(1,2,8,9)$ These generic assessments have usually shown that ${ }^{222} \mathrm{Rn}$ diffusion constitutes the most significant pathway because of inhalation of radon progeny. A wide range of estimated ${ }^{222} \mathrm{Rn}$ 
Table 1. Principal tailings pile radionuclides

\begin{tabular}{|c|c|c|c|c|}
\hline \multirow[b]{2}{*}{ Nucl ide ${ }^{a}$} & \multirow[b]{2}{*}{ Half-life } & \multicolumn{2}{|c|}{ Primary deca } & \multirow{2}{*}{$\frac{\text { modes }}{r}$} \\
\hline & & $a$ & $B$ & \\
\hline \multicolumn{5}{|c|}{ Uranium scries } \\
\hline $238 U$ & $4.5 \times 10^{9} y$ & $x$ & & \\
\hline $234 \mathrm{Th}$ & $24 d$ & & $x$ & $x$ \\
\hline $234 \mathrm{mPa}$ & $1 \mathrm{~m}$ & & $x$ & $x$ \\
\hline $234 \mathrm{U}$ & $2.5 \times 10^{5} y$ & $x$ & & \\
\hline ZsUTh & $8 \times 10^{4} y$ & $x$ & & \\
\hline $226 \mathrm{Ra}$ & $1.6 \times 10^{3} \mathrm{y}$ & $x$ & & $x$ \\
\hline $22 \angle R n$ & $3.8 d$ & $x$ & & \\
\hline $218 \mathrm{Po}$ & $3.1 \mathrm{~m}$ & $x$ & & \\
\hline $214 \mathrm{~Pb}$ & $26.8 \mathrm{~m}$ & & $x$ & $x$ \\
\hline $214 \mathrm{Bi}$ & $19.7 \mathrm{~m}$ & & $x$ & $x$ \\
\hline $214 \mathrm{Po}$ & $160 \mu \mathrm{s}$ & $x$ & & \\
\hline $210 \mathrm{~Pb}$ & $21 y$ & & $x$ & $x$ \\
\hline $210 \mathrm{Bi}$ & $5 d$ & & $x$ & \\
\hline $210 P_{0}$ & $138 \mathrm{~d}$ & $x$ & & \\
\hline $206 \mathrm{~Pb}$ & Stable & & & \\
\hline \multicolumn{5}{|c|}{ Actinium serics } \\
\hline $235 U$ & $7 \times 10^{8} y$ & $\mathbf{x}$ & & $x$ \\
\hline $231 \mathrm{Th}$ & $26 \mathrm{~h}$ & & $x$ & $x$ \\
\hline $231 \mathrm{~Pa}$ & $3.3 \times 10^{4} y$ & $x$ & & $x$ \\
\hline $227 \mathrm{AC}$ & $21.6 y$ & & $x$ & \\
\hline${ }^{227} \mathrm{Th}$ & $18 \mathrm{~d}$ & $x$ & & $x$ \\
\hline $223 \mathrm{Ra}$ & $11.4 \mathrm{~d}$ & $x$ & & $x$ \\
\hline $2199 \pi$ & $4 s$ & $x$ & & $x$ \\
\hline $215 \mathrm{Po}$ & $1.8 \mathrm{~ms}$ & $x$ & & \\
\hline $211 \mathrm{~Pb}$ & $36 \mathrm{~m}$ & & $x$ & $x$ \\
\hline $211 \mathrm{Bi}$ & $2.2 \mathrm{~m}$ & $x$ & & $x$ \\
\hline ודי207 & $4.8 \mathrm{~m}$ & & $x$ & \\
\hline $207 \mathrm{~Pb}$ & Stable & & & \\
\hline
\end{tabular}

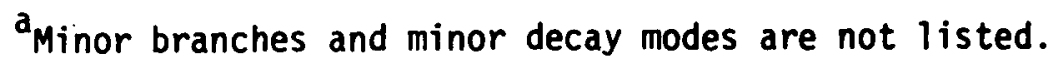


Table 2. Principal radionuclides involved in pathways from tailings piles to man

\begin{tabular}{|c|c|c|c|}
\hline Pathway & Radionuclides & Pathway processes & Exposure hazard \\
\hline $\begin{array}{l}\text { Radon } \\
\text { diffusion }\end{array}$ & $222 R n$ & $\begin{array}{l}\text { Diffusion to pile surface } \\
\text { Atmospheric transport } \\
\text { Inhalation }\end{array}$ & $\begin{array}{l}\text { Inhalation of } \\
218 \mathrm{Po}, 214 \mathrm{~Pb} \\
214 \mathrm{Bi}, 214 \mathrm{Po}\end{array}$ \\
\hline $\begin{array}{l}\text { Airborne } \\
\text { activity }\end{array}$ & $230 \mathrm{Th}, \quad 23 \mathrm{lPa}$ & $\begin{array}{l}\text { Resuspension from pile } \\
\text { surface } \\
\text { Atmospheric transport } \\
\text { Inhalation } \\
\text { Body surface contamination }\end{array}$ & $\begin{array}{l}\text { Inhalation of air-- } \\
\text { borne activity } \\
\text { carried by respirable } \\
\text { particles }\end{array}$ \\
\hline Terrestrial & ${ }^{226} \mathrm{Ra}, \quad 210 \mathrm{~Pb}$ & $\begin{array}{l}\text { Resuspension from pile } \\
\text { surface } \\
\text { Atmospheric transport } \\
\text { Deposition on soil or foliage } \\
\text { Uptake by plants } \\
\text { Intake by animals } \\
\text { Consumption of contaminated } \\
\text { plants, meat, and milk } \\
\text { Consumption of contaminated } \\
\text { soil }\end{array}$ & $\begin{array}{l}\text { Ingestion of }{ }^{226} \mathrm{Ra} \text {, } \\
21 \mathrm{~Pb}\end{array}$ \\
\hline Aquatic & $226 \mathrm{Ra}, \quad 210 \mathrm{~Pb}$ & $\begin{array}{l}\text { Dissolution of radionuclide } \\
\text { in pile } \\
\text { Migration through soil to } \\
\text { water } \\
\text { Migration in water } \\
\text { a. Uptake by aquatic } \\
\text { organisms } \\
\text { b. Consumption of aquatic } \\
\text { organism } \\
\text { a. Use of water for } \\
\text { irrigation } \\
\text { c. IIptake hy plants } \\
\text { Consumption of contaminated } \\
\text { drinking water } \\
\text { Immersion in contaminated water }\end{array}$ & $\begin{array}{l}\text { Ingestion of }{ }^{226} \mathrm{Ra} \text {; } \\
\text { whole body gamma } \\
\text { irradiation }\end{array}$ \\
\hline $\begin{array}{c}\text { External } \\
\text { gamma }\end{array}$ & $\begin{array}{l}\text { Daughters } \\
\text { of } 226 \mathrm{Ra}\end{array}$ & $\begin{array}{l}\text { Attenuation by pile material } \\
\text { Air-distance attenuation } \\
\text { External exposure }\end{array}$ & $\begin{array}{l}\text { External exposure to } \\
\text { gamma. radiation pro- } \\
\text { duced by the decay of } \\
226 \mathrm{Ra} \text { and its daughters }\end{array}$ \\
\hline
\end{tabular}


effects has been reported. Klement et al. ${ }^{(8)}$ concluded that no significant risk was imposed upon the public by active and inactive milling sites. They stated that population doses from these sources cannot be distinguished from background. On the other extreme, there are those who have extrapolated Environmental Protection Agency (EPA) assumptions (2) and have concluded that ${ }^{222} \mathrm{Rn}$ released by uranium mill tailings will represent a fatal encounter for millions who will be exposed over a period of 80,000 years. The analysis offered by Sears et al, (9) required many assumptions and was not intended to be applied to any specific site; however, their results indicate that ${ }^{222} \mathrm{Rn}$ progeny may account for $>90 \%$ of the dose to individuals residing in areas adjacent to a tailings pile.

The first step in the radon diffusion pathway is the migration of this inert gas to the surface of the tailings pile. Migration consists of two stages: diffusion of $222 \mathrm{Rn}$ from its point of origination into the intergranular capillary network, and migration through the capillaries to the pile surface.

Only those ${ }^{222} \mathrm{Rn}$ atoms formed by the decay of ${ }^{226} \mathrm{Ra}$ at or very near the surface of a particle are likely to escape from the particle. The fraction of radon which escapes from a particle is called the "emanation factor" or "emanating power." Culot et al. ${ }^{(10)}$ gave an average value for this factor of about $23 \%$ for uranium mill tailings. This is in good agreement with the experimental results obtained for various soils by Sisigina (11) (14 to 29\%) and by Megumi and Mamuro (12) (25\%). 
Radon released to the interstitial pores migrates toward the surface of the pile. It behaves in this manner due to molecular diffusion whereby ${ }^{222} \mathrm{Rn}$ moves from a volume of air at a high concentration (pore air) to a volume whose concentration is lower (atmosphere). The movement of the pore air itself may either enhance or retard the diffusion process. The instantaneous flux of radon across a unit area of the pile surface may be influenced by factors affecting the movement of pore air, for example, atmospheric pressure, ${ }^{(13)}$ temperature differential between atmosphere and tailings, (14) wind speed, (15) atmospheric stability $(15,16)$ and presence or absence of freezing conditions. (15) The movement of pore air has little effect on a long-term average flux because of the cyclical nature of the short-term variations.

The application of Fickian diffusion equations to describe the migration of $222 \mathrm{Rn}$ through tailings material has been developed by Culot et al. (10) who considered a layer of tailings material sandwiched between a concrete cover and an earthen base. A similar approach can be used to derive an equation describing the ${ }^{222} \mathrm{Rn}$ flux diffusing from a bare tailings pile:

$J=\left[\frac{k_{1} q_{1} R E \rho}{p_{1}}\right] \times\left[\frac{k_{2} q_{2} \cosh q_{1} t+k_{1} q_{1} \sinh q_{1} t-k_{2} q_{2}}{k_{1} q_{1} \cosh q_{1} t+k_{2} q_{2} \sinh q_{1} t}\right] \times 10^{4}$,

where

$$
q_{i}=\left[\frac{\lambda p_{i}}{k_{i}}\right]^{1 / 2}
$$


and

$J$ is the ${ }^{222} R$ flux from the pile surface $\left(\mathrm{pCi} / \mathrm{m}^{2}-\mathrm{sec}\right)$,

$K$ is the bulk diffusion coefficient $\left(\mathrm{cm}^{2} / \mathrm{sec}\right)$,

$\lambda$ is the decay constant of ${ }^{22} \mathrm{Rn}\left(2.10 \times 10^{-6} \mathrm{sec}^{-1}\right)$,

$p$ is the porosity of the medium (fraction),

$E$ is the emanation factor,

$R$ is the ${ }^{226} R a$ content of the tailings ( $p(i / g)$,

$\rho$ is the bulk density of the tailings $\left(a / \mathrm{cm}^{3}\right)$,

$t$ is the depth of the tailingis pile $(\mathrm{cm})$,

subscript 1 refers to tailings,

subscript 2 refers to soil below tailings.

The inverse of $q$ is called the "relaxation length"-the thickness of source-free material required to reduce the radon flux to $37 \%(1 / e)$ of $i$ ts original value. The diffusion coefficient, $K$, represents the effect of the properties of the medium on the diffusion process.

Baver ${ }^{(17)}$. presents evidence which indicates that the diffusion coefficient of a porous medium varies inversely with the tortuosity of the medium. The porosity, $p$, which represents the ratio of the crosssectional area of pores compared to the total cross section of the bulk medium, directly affects the value of the diffusion coefficient. $(10,15$, $18,19)$ The pore diffusion coefficient, $D$, is related to the bulk diffusion coefficient by

$$
0=\mathrm{Kp} \text {. }
$$


The effect of moisture in the medium is shown in Fia.? Where Tanner's (18) data is used to solve Eq. (1). These data are in general agreement with the trends noticed by Guedalia et al. (14)

In the application of Eq. (1), it is assumed that the porosity of the medium does not vary with depth; for example, there is no compaction of the medium at lower depths. Furthermore, the properties of the medium represented in Eq. (1) are assumed to be isotropic.

The average ${ }^{222} \mathrm{Rn}$ flux attributable to diffusion can be estimated by applying Eq. (1) to data obtained from onsite physical measurements. The atmospheric dispersion of the ${ }^{22}{ }^{2} \mathrm{Rn}$ from the tailings pile may then be used to estimate the annual average human exposure attributable to this source. Atmospheric dispersion may be calculated by representing the tailings pile as an area or strip source $(20,21)$ and using local meteorological data in a Gaussian diffusion model. (22).

The results of short-term ( 1 week) atmospheric sampling of $22{ }^{2} \mathrm{Rn}$ on and near tailings piles have been reported by Sneling $(23,24)$ and Snelling and Shearer. (25) However, the results reported by Shearer and $\mathrm{Sill}^{(26)}$ indicate that using the results of a short-term sampling program to represent the arinual average can lead to serious errors. Their (26) 57 sampling stations were operated for 48-hr periods at threeweek intervals for a one-year period or about $10 \%$ of the time. The results reported for each sampling station showed ranges of about an order of magnitude because the short-term ${ }^{22} \mathrm{Rn}$ emanation rate from the pile is affected by pore air movements and atmospheric dilution, and dispersion of the emanated radon is affected by the meteorological 


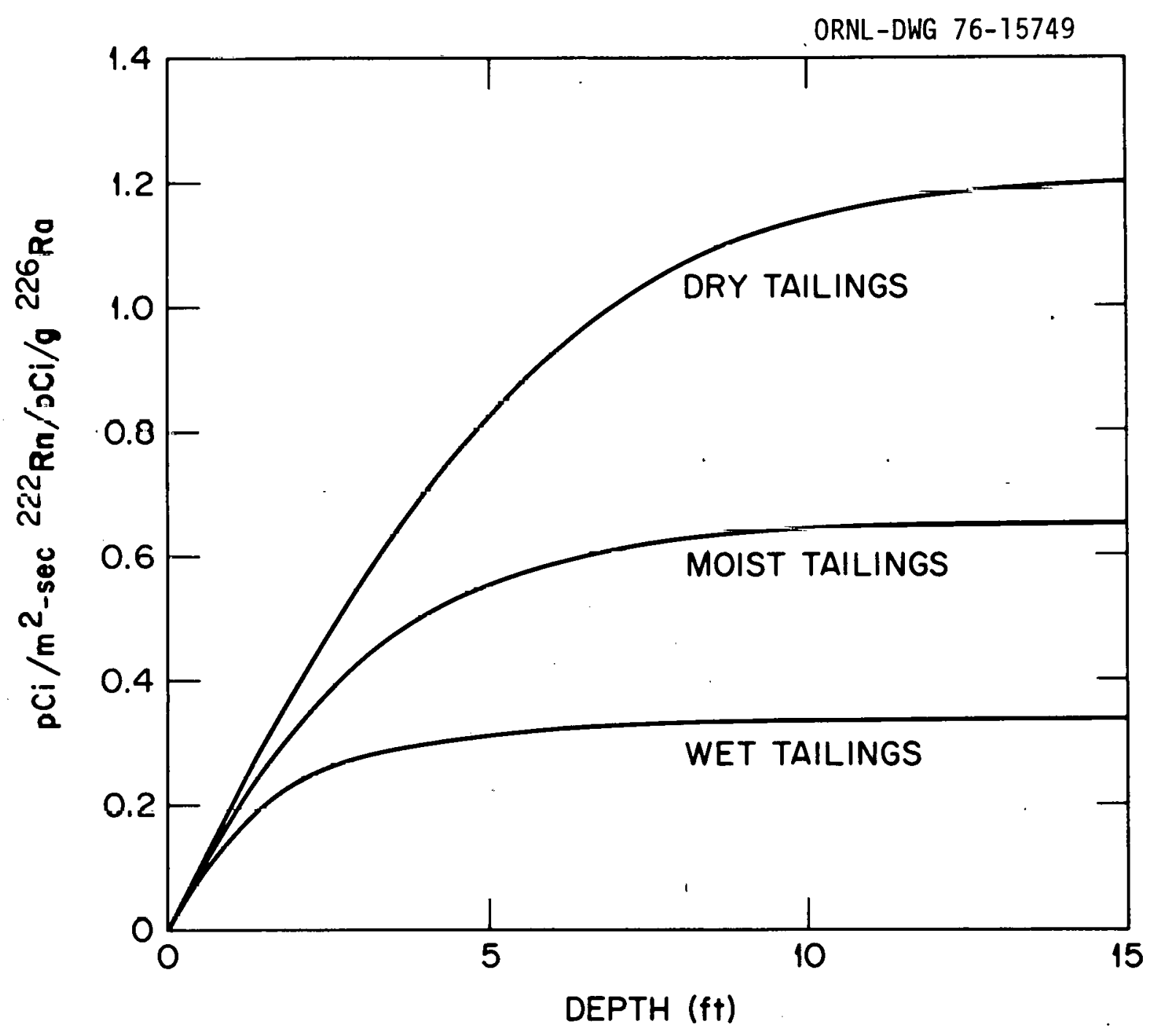

F1g. 2: Graphic representation of radon emanation from wet, moist, and dry tailings as a function of ${ }^{226} \mathrm{Ra}$ concentration and depth of tailings. 
conditions prevailing at the time of sampling. Thus, extrapolation of short-term measurements to represent annual average human exposures can lead to serious errors.

Human exposure attributable to ${ }^{222} \mathrm{Rn}$ emitted by the tailings pile may be estimated conservatively by making the following assumptions:

1. During transport from pile to receptor, no ${ }^{222} \mathrm{Rn}$ is lost by decay, dry deposition, or rainout.

2. The outdoor airborne radon concentration at a height of $3 \mathrm{~m}$ is the same as the ground level concentration calculated by the dispersion model.

3. The fraction of the airborne radon concentration within a habitable structure due to the tailings pile is the same as the outdoor radon concentration attributable to the tailings pile.

4. The individual resides continuously in the structure.

The conversion of an indoor ${ }^{222} \mathrm{Rn}$ concentration to a dose equivalent is dependent on an extensive knowledge of exposure environment and lung dosimetry conditions. Presently, an adequate definition of these conditions is not available for non-mining situations. (27) Epidemiological studies of lung cancer incidence in uranium miners have used exposures estimated in terms of working-level months* (WLM). $(28,29)$ The conversion of the WLM unit to rems can be done only with major uncertainties. (30).

\footnotetext{
"One working level $=1 \mathrm{WL}=$ any combination of short-lived radon daughters in 1 liter of air that has a potential alpha energy of $1.3 \times 10^{5} \mathrm{MeV}$; $1 \mathrm{WLM}=$ exposure at a level of $1 \mathrm{WL}$. for a duration of $170 \mathrm{hr}$.
} 
One can, however, develop a rough correlation between the two measurable factors: cumulative exposure in WLM and number of lung cancers. Even these two factors are difficult to quantify in real life situations. Consequently, radon progeny exposure calculations made in this document will be expressed in terms of WLM, and results of radon progeny measurements will be expressed in terms of WL.

\section{Airborne Activity Pathway}

The suspension of tailings and subsequent transport by wind creates another potential pathway for human exposure. Wind may cause transport by one of three modes: surface creep, saltation, and suspension. Surface creep is illustrated through the movement of large particles moving along the surface due to wind or by the impaction of other particles. Intermediate sized particles move by saltation, wherein the particles are lifted a few feet in the air by wind and quickly return to the surface. The smaller particles, including those in the respirable range, become suspended and remain suspended due to vertical turbulence. The theoretical and experimental studies of these mechanisms are well summarized by Healy(7) and Anspaugh et al. (31)

The quantity of radioactive material suspended is affected by variables such as the topography and physical properties of the surface, the amount and type of vegetative cover, the extent of surface contamination, local micrometeorology, and the time elapsed since the surface was contaminated. Previous resuspension studies have been concerned with agriculturat erosion and resuspension of plutonium contamination. No attempts have been made to determine resuspension rates of tailings, 
although an unverified, theoretical approach has been attempted for instantaneous circumstances. (32)

Most of the previous surveys of airborne activity near uranium mill tailings piles have been of short-term duration. $(23-25,33)$ The work of Breslin and Glauberman $(33,34)$ compared the airborne activities measured near three abandoned tailings piles. They reported that airborne activity concentrations were "trivial" near two of the piles. The third pile was considerably drier than the other two, and "dust devils" were prevalent during sampling. Consequently, the airborne concentrations exceeded maximum permissible concentrations* (MPC's) only at sampling stations downwind of and in close proximity to this pile. Comparable results were obtained in the other short-term surveys. (24-26)

The results obtained by Breslin and Glauberman $(33,34)$ indicate that about one-third of the total suspended activity was associated with respirable particles. Furthermore, about $10 \%$ of the total airborne alpha activity was determined to be water soluble.

A long-term survey was conducted from January, 1974, thru December, 1974, consisting of 26 separate samples of airborne activity at a station on the Salt Lake C1ty, Utah, tailings pile. (35) None of the reported individual samples had activities greater than MPC (10 CFR $20)^{(36)}$ for. ${ }^{226} \mathrm{Ra}, 210 \mathrm{~Pb}, 210 \mathrm{Po}, 230 \mathrm{Th}, 234 \mathrm{U}, 235 \mathrm{U}$, or $238 \mathrm{U}$.

\#Breslin and Glauberman $(33,34)$ compared their measured values with those recommended in National Bureau of Standards Handbook 69. 
In addition to inhalation of respirable airborne activity, the contamination of body surfaces and clothing by airborne particles should be considered. This has been done by Healy $(7)$ for plutonium contamination. He concluded that inhalation of airborne material imparts a much greater hazard.

Deposition of particles between the source and the receptor will reduce the airborne activity pathway hazard in relation to that associated with the radon diffusion pathway. Thus, it appears that the contribution of the airborne activity pathway to total exposure is only a small fraction of that attributable to radon diffusion; hence it is ignored in this assessment study.

\section{Terrestrial Pathway}

The terrestrial pathway is a means by which the deposited airborne activity may reach man. Radionuclides may be deposited on edible foliar surfaces, migrate through the soil into edible crops, or be consumed by animals which provide meat or milk. The radionuclides found in uranium tailings have concentration factors in crops, meat, and milk which are generally much less than unity. ${ }^{(6)}$ The worst case would likely be the direct ingestion of contaminated soil. If it is assumed that a total of $1 \mathrm{~g}$ of the top $1 \mathrm{~cm}$ of contaminated soil is ingested daily, ${ }^{(7)}$ the upper limit of $2 \mathrm{pCi} / \mathrm{day}{ }^{(37)}$ would restrict the soil activity to $2 \mathrm{pCi} / \mathrm{g}$ of ${ }^{226} \mathrm{Ra}$. This would result in an areal activity of $3.2 \times 10^{4} \mathrm{pCi} / \mathrm{m}^{2}$ for a soil density of $1.6 \mathrm{~g} / \mathrm{cm}^{3}$. The observed annual average airborne concentration of ${ }^{226} \mathrm{Ra}$ measured over the Salt Lake City pile was 0.002 $\mathrm{pCi} / \mathrm{m}^{3} .^{(35)}$ According to data presented by Healy, ${ }^{(7)}$ deposition velocities 
are on the order of $0.5 \mathrm{~cm} / \mathrm{sec}\left(1.6 \times 10^{5} \mathrm{~m} /\right.$ year $)$ for a semi-arid topography. The deposition of contamination, assuming that a concentration of $0.002 \mathrm{pCi} / \mathrm{m}^{3}$ remains undiluted and is deposited on contamination-free land, will be $2 \times 10^{-3} \mathrm{pCi} / \mathrm{m}^{3} \times 1.6 \times 10^{5} \mathrm{~m} /$ year or 3.2 $\times 10^{2} \mathrm{pCi} / \mathrm{m}^{2}$ year. Assuming that there are no erosional losses of activity, the time required for the activity of the top $1 \mathrm{~cm}$ of soil to approach $2 \mathrm{pCi} / \mathrm{g}$ is on the order of 100 years. Because the radionuclides are fixed in fine-grained sands, these values hold for most other uranium chain daughters.

A study of foodstuffs in the Durango and Grand Junction, Colorado, areas $(38)$ concluded that daily dietary intakes of $226 \mathrm{Ra}$ in these areas were similar to intakes reported by other U.S. cities which have no uranium tailings nearby.

Thus, based on present information, the terrestrial pathway appears to be inconsequential as a source of human exposure.

\section{Aquatic Pathway}

Aquatic pathways are highly site specific. The proximity of the site to ground-or surface-water supplies, the presence of leaky aquifers, and the values of local geohydrologic parameters w111 determine the magnitude of the hazard associated with this pathway. Surface-water erosion would result in runoff water contaminated primarily by particulate activity scoured from the tailings pile surface.

No evidence of water contamination by ${ }^{226}$ Ra existed in the surveys performed by Snelling $(23,24)$ and Snelling and Shearer. (25) However, concentrations of uranium three orders of magnitude above background were found in groundwater sources near Mexican Hat, Utah, tailings 
pile. (23) Gera ${ }^{(6)}$ attributes the mobility of uranium in groundwater to the presence of oxidizing conditions. The uranyl ion $\left(\mathrm{UO}_{2}^{++}\right)$is chemically stable, highly soluble, and readily forms anionic complexes. These properties which enhance the mobility of uranium are not exhibited to an appreciable extent by the other nuclides in tailings.

The leachability of ${ }^{226}$ Ra from tailings and river sediments was studied by Shearer and Lee ${ }^{(39)}$ who found that only the liquid to solid ratio was of any importance. On the other hand, Havlik et al. $(40,41)$ found that the chemical composition of the leaching solution, particularly the presence of the $\mathrm{Cl}^{-}$ion, had the greatest significance. A comparison of the results of these leachability studies indicates that the mineralogy of the adsorbent may also influence the solution behavior of ${ }^{226} \mathrm{Ra}$. Gera ${ }^{(6)}$ presents data which indicate that the distribution coefficient, $K_{d}$, for radium in some Russian mineral springs ranges from 87 to well over $10^{6} \mathrm{ml} / \mathrm{g}$. Measured values of $K_{d}$ for carbonate leached tailings have ranged between 1000 and $2000 \mathrm{ml} / \mathrm{g}$ for ${ }^{226} \mathrm{Ra}$. (42) Typical values of $K_{d}$ for Ra with a sandy soil adsorbent are reported as about 100 , whereas $K_{d}$ for $U, T h$, and $P b$ is in excess of 1000. (9)

The velocity for a groundwater contaminant is given by the expression $^{(43)}$

$$
v_{c}=v_{w}\left[\frac{1}{1+\frac{\rho K_{d}}{p}}\right] \text {, }
$$


where $V_{c}$ is the velocity of the contaminant (m/year),

$V_{W}$ is the groundwater velocity (m/year),

$K_{d}$ is the distribution coefficient $(\mathrm{ml} / \mathrm{g})$,

$\rho$ is the bulk density of the medium $(g / c c)$,

$p$ is the porosity of the medium.

For a system with a $K_{d}$ of 100 , $\rho$ of 1.6 , and $p$ of 0.4 , the contaminant velocity will be $2.5 \times 10^{-3} \times V_{w}$. This calculation indicates that the annual migration of ${ }^{226} \mathrm{Ra}$ for a water velocity of $300 \mathrm{~m} /$ year will be about $0.75 \mathrm{~m}$. On the other hand, uranium migrating as anionic uranyl complex will migrate nearly as fast as the groundwater. Thus, uranium may have greater mobility in this pathway than radium.

The aquatic pathway may be of importance if a leaky aquifer containing potable water is in contact with the leached contamination. The adsorptive capacity of the subsoil will usually inhibit the movement of all tailings radionuclides except uranium migrating as an anionic uranyl complex. Thus, site specific parameters affect the importance of this pathway. The clayey nature of the soil underlying the Vitro tailings coupled with the fact that the site rests on an artesian groundwater system helps to minimize the downward movement of radionuclides through groundwater.

\section{External Gamma Radiation}

Gamma radiation coming directly from the tailings pile or from windblown material is expected to make a minor contribution to the overall exposure of man. However, there are some areas where increased levels of gamma radiation have been observed. Included are areas along public roads near the Vitro mill property, in commercial buildings built 
over tailings, and in or near structures where tailings have been removed from the pile itself. It has been shown in reports of investigations at other mill sites ${ }^{(23-25)}$ that external gamma radiation levels decrease rapidiy with distance from the pile. This observed decrease with distance does not follow the typical inverse square relationship because of the large physical size of the pile.

Exposure of individuals on or near the pile is due to both "primary beam" or unscattered photons from nearby tailings material and gamma rays which originate at other more distant points and reach the individual through air scattering processes. In cases where structures are built over tailings, practically all gamma rays are attenuated to some degree by the floor and other building material and, because of the relatively small total source area, represent a hazard only in the immediate vicinity (1.e., it is unlikely that tailings underlying one building would create an exposure hazard at an adjacent site). 


\section{RADIOLOGICAL MEASUREMENTS AND TECHNIQUES}

Radionuclide Concentration as a Function of Depth in Soil

A monitoring and sampling procedure was established for this project in conjunction with the engineering firm of Ford, Bacon and Davis, Utah. A set of 6-in. holes was drilled through the tailings and into the subsoil. A length of PVC pipe (3-in. O.D.), sealed on one end, was lowered into the hole and measurements were made of gamma-ray intensities as a function of depth. A 6-in.-long Geiger-Muller tube shielded with lead containing collimating slits was positioned inside the PVC tube for measurements. Signals from this tube were counted using a portable scaler. (44)

After gamma ray vs depth profiles were determined, the position of the interface between tailings and subsoil was estimated. The drilling rig was moved approximately $4 \mathrm{ft}$ and another hole was drilled with an auger bit to the interface level. Samples of soil core were then collected as a function of depth using a split-spoon sampler (each core section was $2 \mathrm{ft}$ long). Most of the holes in the tailings area contained water due to the shallow groundwater table. This water made it difficult to obtain uniform samples, introduced some uncertainty in the location of samples, and contributed to contamination of the subsoil by washing fine particles from the side wall of the tailings hole into the water and, subsequently, into the bottom of the hole.

Most of the penetrating gamma radiation monitored in these holes was attributable to radium and its daughters. Therefore, a calibration 
factor for ${ }^{226}$ Ra concentration was determined for the collimated gammaray probe by comparing the response of this unit (counts per unit time) with an estimate of the radium concentration $(\mathrm{pC} i / g)$ determined by counting soil samples using gamma spectroscopy techniques. A least squares fit of the data from this comparison yields the equation

$$
R=0.29 C-20 .
$$

For this case, $R$ is the ${ }^{226} \mathrm{Ra}$ activity in $\mathrm{pCi} / \mathrm{g}$ and $\mathrm{C}$ is the observed response of the collimated gamma-ray detector in counts/min. The correlation coefficient for this equation is $\mathbf{0 . 9 9 6}$.

The above expression was useful in estimating the overall distribution of radioactivity in the tailings as well as the total quantity of radium in the impounded tailings area. On the basis of the quantity and grade of ore processed in the plant, the total radium activity in the tailings pile is 1380 curies. (3) The total ${ }^{226} \mathrm{Ra}$ activily based un the field survey of total tailings mass and overall distribution as determined by the gamma logging technique was 1400 curies.

Soil samples taken from the split-spoon core sections were prepared using facilities at the U. S. Bureau of Mines Laboratory in Salt Lake City. Each sample was dried for $24 \mathrm{hr}$ at $110^{\circ} \mathrm{C}$ in order to remove all moisture. The samples were then pulverized in a high speed rotary crusher and sieved for a particle size $\leq 500 \mu \mathrm{m}$. The snil was dispensed into $30-\mathrm{ml}$ polyethylene vials normally used for liquid scintillation counting.

Each vial was weighed, sealed tightly and labeled as follows: 


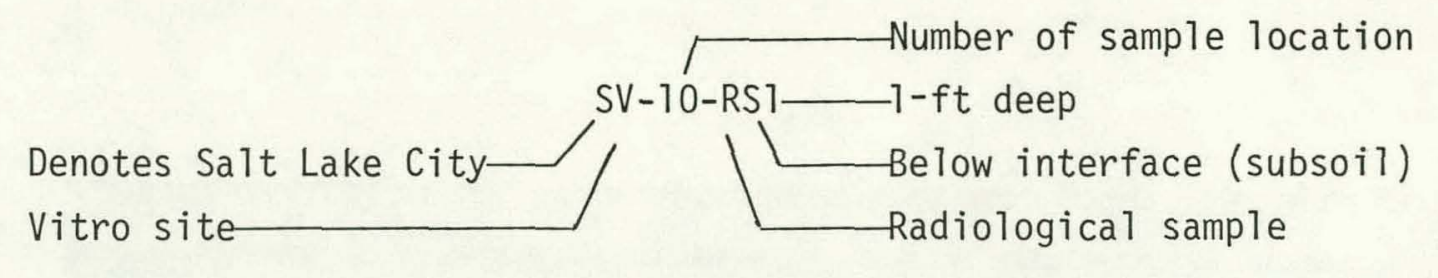

DATE - September 26, 1975

Date bottle sealed-

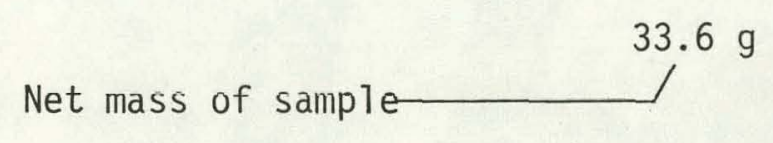

Unfortunately, the presence of water in most of the core holes prevented the collection of a uniform sample, and at many specific points the mass of sample was significantly less than optimum. The sample vials were sealed tightly and stored for a period sufficient to allow the equilibration of radon and its daughters. Radon-222, which has a radioactive half-life of 3.8 days, will reach the same activity as its long- lived parent, ${ }^{226} \mathrm{Ra}$, in about 30 days. The short-lived progeny of ${ }^{222} \mathrm{Rn}$ will have reached equilibrium within the same time period. Determination of the activity of any of the daughters in the sample will reflect ${ }^{226} \mathrm{Ra}$ activity. After equilibration of radon daughters, up to 12 sample vials were inserted into a sample carousel or holder (Fig. 3) that was placed on a $\mathrm{Ge}(\mathrm{Li})$ detector.

Water samples were collected at several points in a ditch used to drain outfall from the nearby sewage treatment plant. Water samples were also collected from Mill Creek, Jordan River, four wells off-site, 


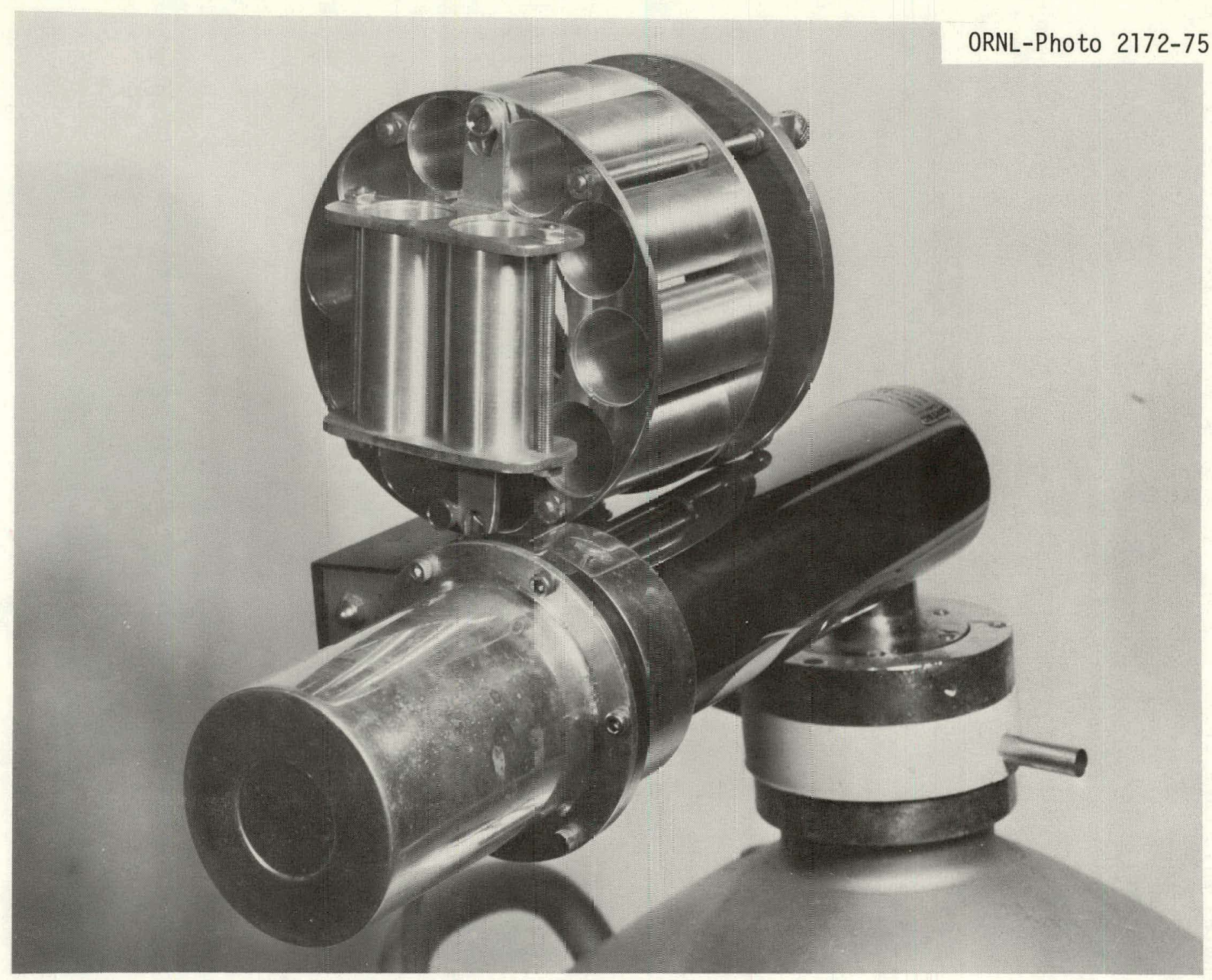

Fig. 3. View of horizontal $\mathrm{Ge}(\mathrm{Li})$ detector and sample "carousel" holder used for gamma-ray spectroscopy. 
and each hole which had been bored through the tailings. These latter samples, taken evenly throughout the depth of water in each hole, were collected by the survey crew and stored for later analysis. All water samples were centrifuged and pressed through a $0.45-\mu \mathrm{m}$ filter to clear suspended solids. The samples were then analyzed using radiochemistry techniques. A plan view of the major sample locations is shown in Fig. 4. Water and stream sediment samples were collected at points shown on Fig. 5.

Field Laboratory Facilities and Equipment

Two facilities were established in Salt Lake City, at the General Services Administration's Administration Building and compound in southwest Salt Lake City.

A 20-ft mobile laboratory van was used to determine radon and radon progeny concentrations, gamma-ray intensities, and for weighing, packaging, and storing soil samples. This lab contained an alpha spectroscopy counting system for air samples along with air sampling equipment, a Johnston Laboratory radon monitor complete with six Lucas flasks and evacuation manifold, gamma-ray detectors, miscellaneous electronic testing equipment, and standard calibration sources. A trailer-mounted, gasoline-powered $12 \mathrm{~kW}$ motor generator was pulled by the van to supply electrical power in remote locations. A voltage stabilizer was used to provide regulated power for instruments.

The second field laboratory used in the project was an $8 \times 35 \mathrm{ft}$ air-conditioned semitrailer with running water, tools, miscellaneous supplies, two gamma counting systems, and computer. It served as a counting room, office, and workshop. This trailer required electrical 


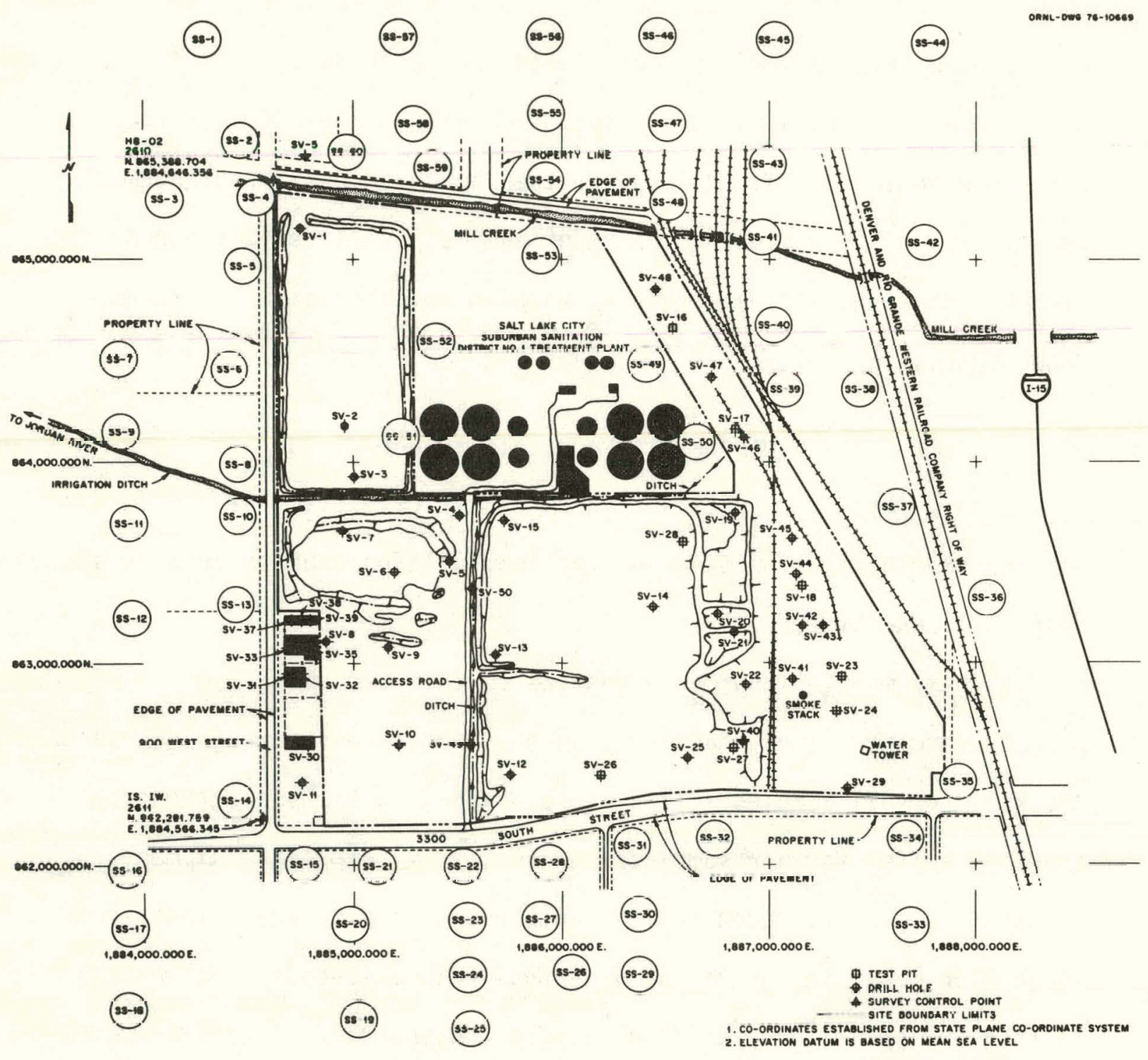

76-10669 Fig. 4. Plan view of the Vitro mill site showing core hole and offsite sample locations. 
ORNL DWG. $77-4329$

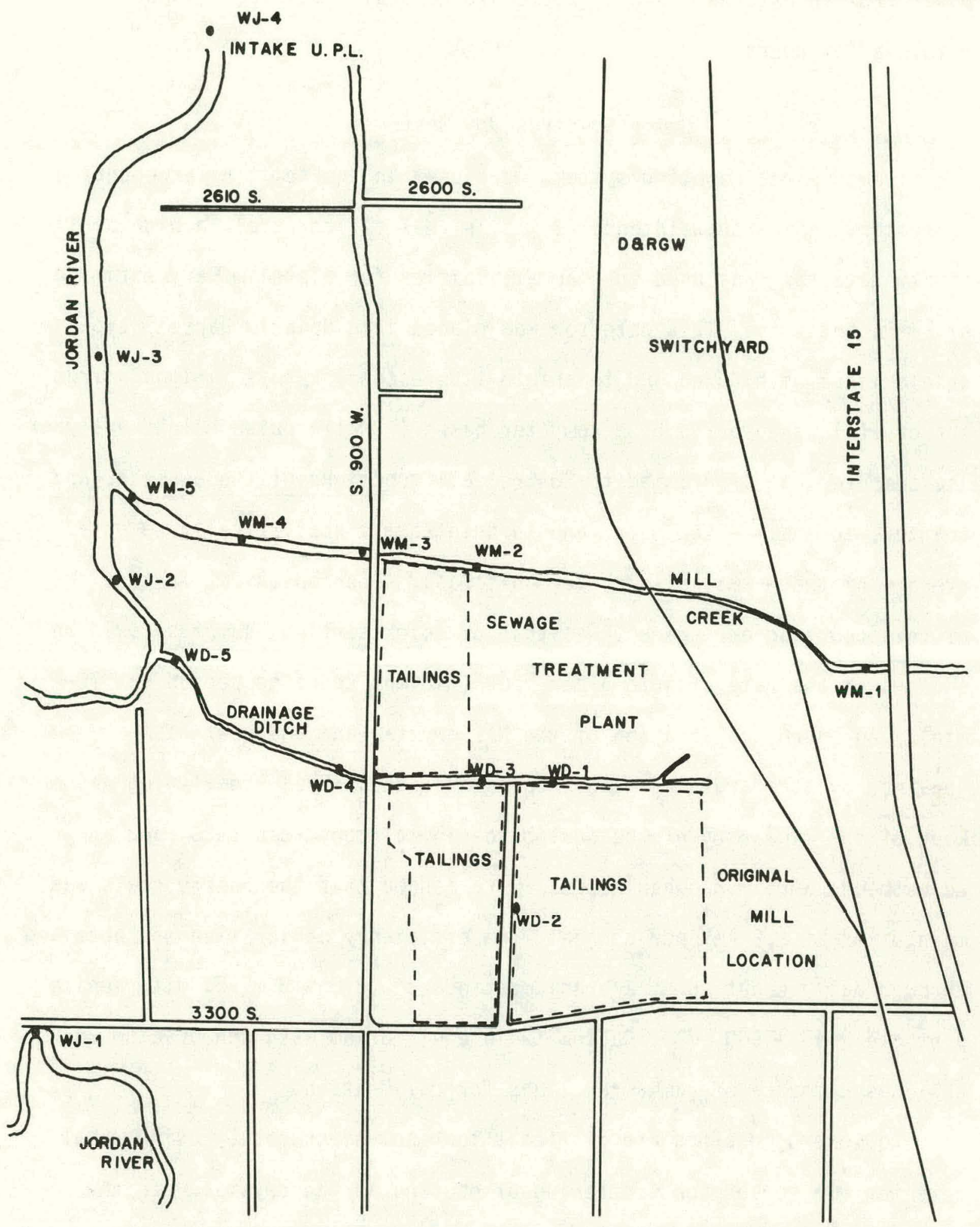

Fig. 5. Plan view of the Vitro mill site showing location of water samples collected in surface streams. 
power from an external source, but could generally be placed in service within a few hours.

\section{Gamma Spectroscopy Systems}

Two complete counting systems were used in the semitrailer counting 1aboratory. A Harshaw integral $3 \times 3$ in. NaI (TI) crystal, a high sensitivity detector, was used to scan all samples for a preliminary estimate of ${ }^{226} \mathrm{Ra}$ activity. This detector was placed in a "pickle barrel" lype shield lined with $\mathrm{Cu}$ and $\mathrm{Cd}$ to shield fluorescence $\mathrm{x}$ rays. Signals trom the crystal were sorted by a computer based (PDP-11) pulse height analyzer. The computer was programmed to control all functions of the analyzer and counter, to analyze the data, and to print out a statistically weighted average of the ${ }^{226} \mathrm{Ra}$ activity per unit mass. One convenient feature of this counting arrangement was that of quick sorting; samples could be scanned at the rate of 4 to 5 per hour (minimum counting period was 10 min). An energy calibration of the Nal crystal and analyzer was obtained by standardizing with ${ }^{57} \mathrm{Co},{ }^{137} \mathrm{Cs}$, and ${ }^{60} \mathrm{Co}$. A daily log was kept of the linearity of the analog-to-digital converter (ADC) and adjustments were made when necessary to assure that the energy scale was maintained at $3.8 \mathrm{keV}$ per channe1. An efficiency calibration was obtained through daily counting of a uranium standard* $(0.05 \% \mathrm{U}$ mixed with dunitc, particle size $=500 \mu \mathrm{m})$. Radium is in equilibrium with the uranium and provides a source of gamma-ray lines for calibration.

Low energy photons are difficult to resolve accurately using a $\mathrm{NaI}$ detector due to Compton scattering of photons in the crystal. In the interest of time, rapid screening was undertaken and preliminary ${ }^{226} \mathrm{Ra}$

\footnotetext{
* Standard uranium sample obtained from the New Brunswick Laboratory.
} 
concentrations were determined by observing signals from three high energy photons of ${ }^{214} \mathrm{Bi}$, one of the short-lived daughters of radon. The energies of these photons are $609 \mathrm{keV}, 1120 \mathrm{keV}$, and $1764 \mathrm{keV}$. The samples were stored as described above to allow equilibrium of ${ }^{226} \mathrm{Ra}$ with radon and daughters. In order to accomplish screening, a code was written for the PDP-11 computer which controlled data acquisition for the $\mathrm{NaI}$ system. The reduction of data was simplified by subtracting the Compton contribution from a region comprising the photopeaks of interest. The Compton contribution was determined by taking the average counts in three channels on each side of the photopeak region of interest; this value times the total number of channels comprising each photopeak region was subtracted from the total number of counts in the region. The net value was then compared to the instrument's response to the above-mentioned counting standard whose concentration of ${ }^{226}$ Ra was known. The concentration of ${ }^{226} \mathrm{Ra}$ in each soil sample was determined by comparing the unknown soil concentration to the standard.

Final results of ${ }^{226} \mathrm{Ra}$ in soil were determined by counting all samples with a high resolution $\mathrm{Ge}(\mathrm{L} i)$ detector. This high resolution counting system consisted of a horizontally mounted $50-\mathrm{cm}^{3} \mathrm{Ge}(\mathrm{Li})$ crystal positioned on a platform for movement into and out of a lead shield (see Fig. 6). The detector was used to obtain a complete photon spectrum of the soil samples. Signals from the crystal were routed to a 4096channel pulse height analyzer and counted for a period long enough to evaluate the ${ }^{226} \mathrm{Ra}$ concentration to a statistical accuracy of $\pm 5 \%$ or better. The spectra were recorded on magnetic tape and stored for 


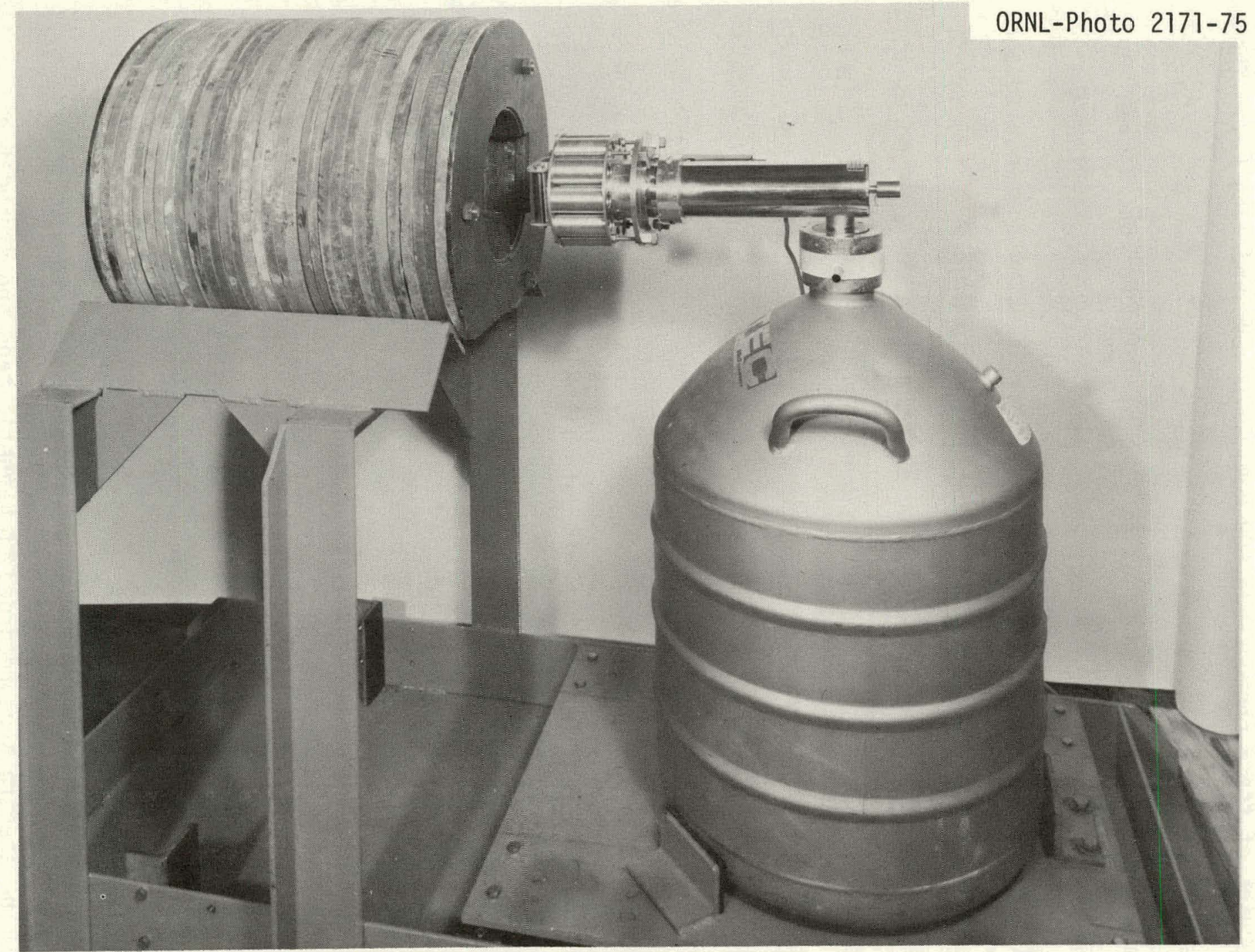

Fig. 6. $\mathrm{Ge}(\mathrm{Li})$ detector and lead shield arrangement used for countinc soil and sediment samples 
complete analysis by computer later. In addition, data for each of several peaks corresponding to individual photons from radon daughters were recorded on paper tape. From the field laboratory in Salt Lake City, these paper tapes were read into the PDP-10 computer at ORNL on a time sharing basis via teletype and FTS phone service at the end of each day.

Energy calibration of the $\mathrm{Ge}(\mathrm{Li})$ detector was controlled through the use of isotopic sources of ${ }^{57} \mathrm{Co},{ }^{22} \mathrm{Na},{ }^{137} \mathrm{Cs},{ }^{60} \mathrm{Co},{ }^{88} \mathrm{Y}$, and ${ }^{40} \mathrm{~K}$. A calibration check was completed each day prior to beginning sample counting. In order to maintain linearity of the ADC, a spectrum stabilizer was utilized. This instrument is adjusted so that two individual photon energies are detected and maintained in two channels at separate ends of the scale. These two calibration points helped maintain an energy span of $1 \mathrm{keV}$ per channel. Efficiency calibration was obtained through the use of the uranium ore standard samples as were used for the NaI crystal. An analysis of the counting data is accomplished through a linear least squares fitting routine. Net adjusted areas under photo peaks of interest are compared with an extensive radionuclide 1 ibrary. ${ }^{(45)}$ Data from the computer are presented for each radionuclide as a weighted mean with standard deviation.

\section{Externa1 Gamma-Ray Detector}

A gamma radiation survey was made on and around the mill site and tailings pile. The instrument used for these measurements was a "Phil" gamma-ray dosimeter. ${ }^{(46)}$ The basic unit is a $6-\mathrm{in}$. 1ong $30 \mathrm{mg} / \mathrm{cm}^{2} \mathrm{glass-}$ walled organic filled Geiger-Muller (G-M) tube with an energy compensation shield made of tin and lead. Pulses from this unit are counted 
with a battery-powered portable scaler. Typically, G-M counters are not used for dosimeters because of a peaked response at low photon energies. However, perforated layers of tin $(1.0 \mathrm{~mm})$, and lead $(0.1$ $\mathrm{mm}$ ), may be used as an energy compensation filter to flatten this peaked response at photon energies below about $200 \mathrm{keV}$. The energy response of this counter and filter arrangement has been demonstrated by Thorngate. Sealed sources of ${ }^{137} \mathrm{Cs}$ and ${ }^{226} \mathrm{Ra}$ were used for calibration. It. was found that the response of this detector was:

$$
1 \mathrm{mR} / \mathrm{hr}=3400 \text { counts } / \mathrm{min} \text {. }
$$

For each gamma-exposure rate reading, a minimum of three 1-min counts were recorded. The means of these readings (less background) were used to determine the exposure rate to external gamma rays.

\section{Radon Daughter Sampler}

Radon daughter concentrations were measured with a sampling and counting instrument which has been in use at ORNL for several years ${ }^{(48)}$ and used briefly in the remedial action program in Grand Junction. (49) The filter counter for this sampling device, as shown in Fig. 7 , utilizes a modified gas flow alpha counter for housing a $600 \mathrm{~mm}^{2}$ silicon diode. Normally, this type detector is operated in a vacuum chamber. However, in this case, it was found that by flowing helium at atmospheric pressure through the assembly, absorption of alpha particles was small relative to absorption in air. Furthermore, it was not necessary to cycle the bias voltage of the diode because there were no changes in pressure. 


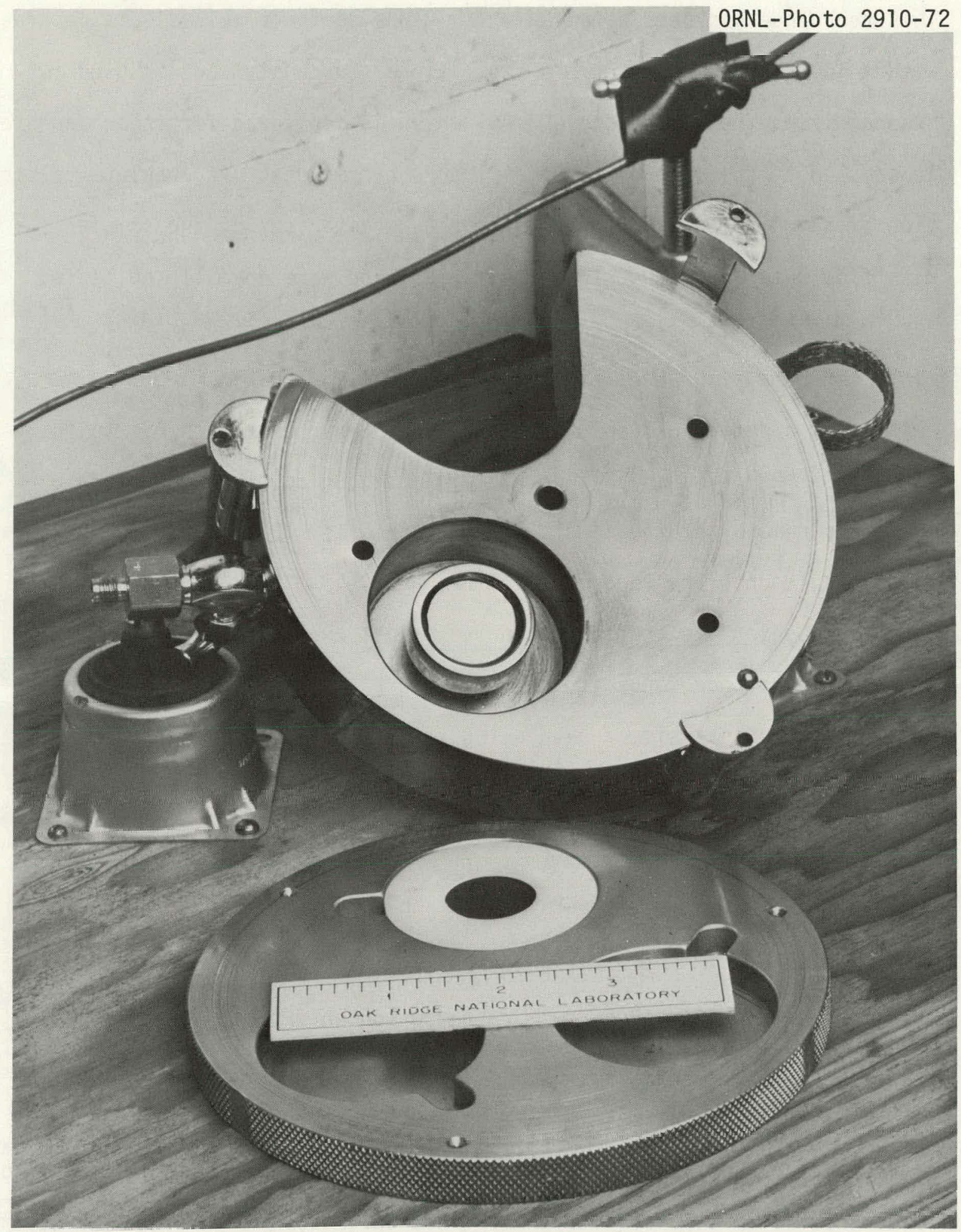

Fig. 7. Exploded view of system used to count radon daughters collected on filters, showing silicon detector, housing, and sample tray. 
This technique has been patented. ${ }^{(50)}$ Alpha particle pulses were recorded with a 100 channel analyzer. A small alpha source standard is used for standardizing the energy scale. Air which is monitored for radon daughters is sampled at the rate of 12 to 14 liters per minute. An absolute calibration of the airflow was provided through a comparison of the sampler's mass flow meter and a wet test meter. Samples were normally collected for $10 \mathrm{~min}$, and the first count of the filter was started at 2 min after removal of the sample and continued for 10 min. For this case, a determination was made of the number of counts due to the decay of ${ }^{218} \mathrm{Po}(\mathrm{RaA})$ and ${ }^{214} \mathrm{Po}\left(\mathrm{Rac}^{\prime}\right)$. A second count was started 15 min after removal of the sample and continued for $15 \mathrm{~min}$. In this case, counts are recorded from the decay of ${ }^{214} \mathrm{Po}\left(\mathrm{RaC}^{\prime}\right)$. Data from the counter are stored in a pulse height analyzer and reduced by computer. The code for this analysis is explained in detail elsewhere. Results of the analysis of data using this code are presented as concentrations of $R a A, R a B$, and $R a C$. In addition, a value for the working level concentration is also provided along with an estimate of the error associated with each reported value.

\section{Radon Monitor}

The instrument used to measure radon concentrations in air consists of a series of 95-III Lucas chambers and a readout unit.* Each chamber is evacuated to approximately $1-\mathrm{mm} \mathrm{Hg}$ and then opened to atmospheric pressure in the area where a radon measurement is required. No filtration is used for sampled air. The short-lived daughters of radon drawn into the chamber are allowed to decay prior to counting the flask. The

\footnotetext{
* System was manufactured by Johnston Laboratories, Inc.
} 
results from this instrument and the radon progeny monitor provided an estimate of the degree of equilibrium between radon and its daughters in the selected locations where air samples were taken. 


\section{EXPERIMENTAL RESULTS}

During the course of this assessment program, numerous measurements were made to characterize the spread of contamination from the tailings pile to adjacent areas. When the program began, plans called for the measurement of radium concentrations in samples of soil and water and the determination of concentrations of radon and radon progeny in air in selected locations. While field work was in progress, it was decided to extend the studies to include assays for $210 \mathrm{~Pb}$ and $230 \mathrm{Th}$ in soil and water samples collected in or near points of public access. Most of these additional measurements were made for samples collected in surface stream beds in the immediate area and in areas influenced by surface runoff. Only those results which are important to the consideration of health effects are reported here.

\section{Background Radionuclide Concentrations}

Remedial action may be required at the Vitro mill site and at others in western states. The extent of remedial action is dependent on the projected health effects for each site and on the projected cost per health effect avoided. In some cases, remedial action may involve removal of the tailings to a remote site of low population density. In the event tailings are removed, an acceptable standard must be adopted.

In order to evaluate the practicability of a cleanup criterion of twice background for the residual radium contamination levels in soil, it was necessary that the average concentration of radium in soils be determined for the general area of the Vitro site. Samples of soil were collected throughout the Salt Lake Valley ranging from Ogden to Provo 
on a north-to-south 1 ine and from the shore of the great Salt Lake to the foothills of the Wasatch Mountain range as shown on the map in Fig. 8. These soil samples were analyzed for ${ }^{226} \mathrm{Ra},{ }^{232} \mathrm{Th}$, and ${ }^{238} \mathrm{U}$. The results of these determinations are given in Table 3. Background ${ }^{226} \mathrm{Ra}$ concentrations are distributed log-normally and are best described by a geometric mean of $1.46 \mathrm{pCi} / \mathrm{g}$ and a geometric standard deviation of 1.23 .

Anspaugh ${ }^{(52)}$ reports that in approximately 100 sample locations in Utah (in no case was it likely that the Vitro pile was contributing to the measurement) determinations of the soil radium concentration varied from $0.38 \mathrm{pCi} / \mathrm{g}$ to $2.97 \mathrm{pCi} / \mathrm{g}$. The geometric mean of these values was found to be $0.87 \mathrm{pCi} / \mathrm{g}$, and the geometric standard deviation was 1.4 . Most of these measurements were made in situ using a Ge(Li) detector and a computer based pulse height analysis system. $(52,53)$ Results obtained by this technique were within $10 \%$ of the values determined by radiochemical and mass spectrometric analyses.

Pendleton ${ }^{(54)}$ reported measurements of radium "equivalents" in soil samples which had been sealed for ingrowth of radon daughters-a technique similar to that used in this investigation. His samples were collected over a wide area of the Salt Lake Basin and were generally representative of the concentration of radium to a depth of $10 \mathrm{~cm}$ below the surface. Individual samples of each centimeter of soil were collected. A comparison was made between some of Pendleton's results of soil activity measurements and results of this study. In two sets of samples taken in Magna, Utah, he reported an average for ${ }^{26} \mathrm{Ra}$ of $1.1 \pm 0.17 \mathrm{pCi} / \mathrm{g}$ 


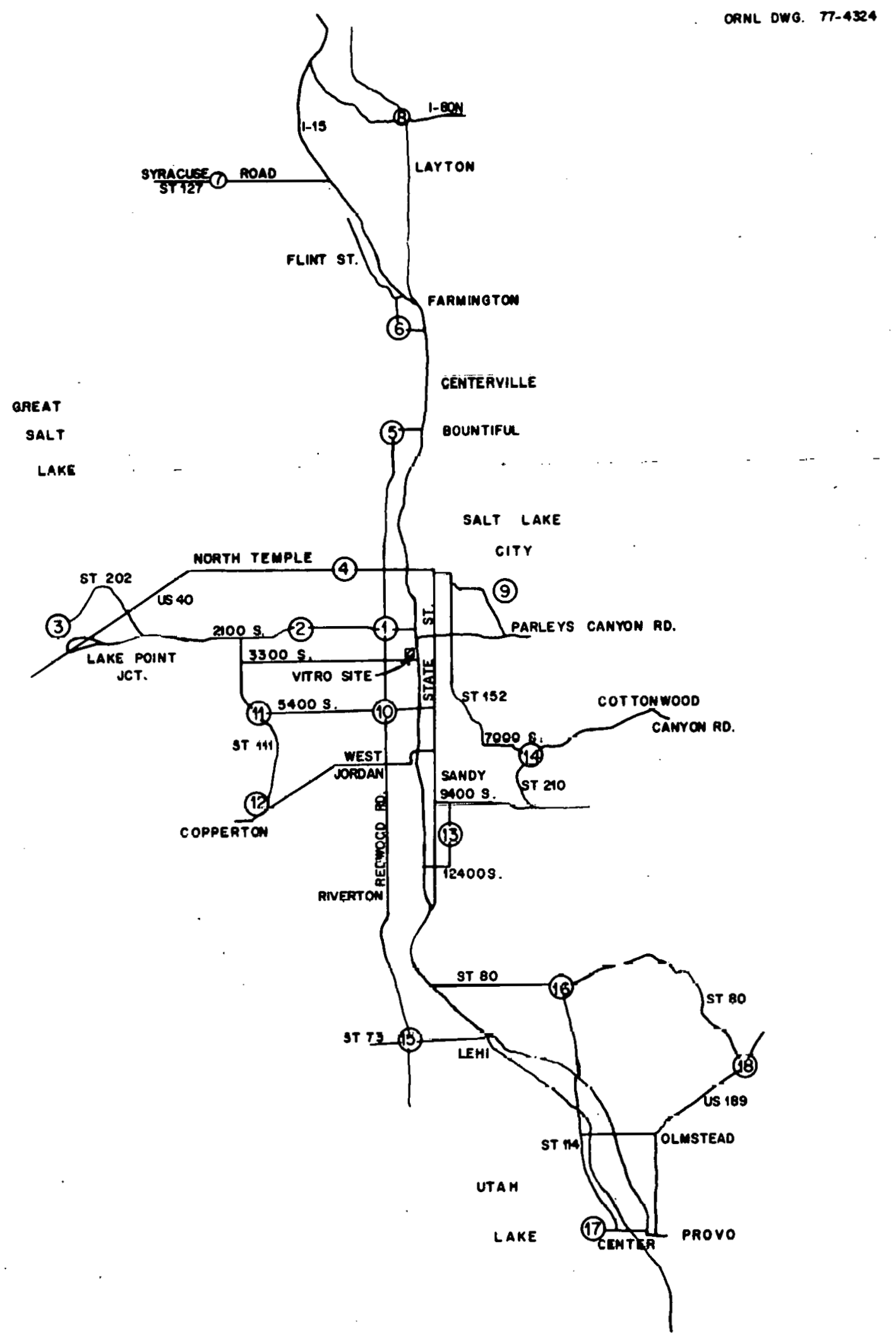

Fig. 8. Map of Salt Lake Valley showing location of background soil samples. 
Table 3. Background radionuclide concentrations in soil samples in the Salt Lake Valley

\begin{tabular}{|c|c|c|c|}
\hline \multirow[b]{2}{*}{$\begin{array}{l}\text { Sample } \\
\text { number }\end{array}$} & \multicolumn{3}{|c|}{ Nuclide concentration } \\
\hline & $\begin{array}{c}226 \mathrm{Ra} \\
(\mathrm{pCi} / \mathrm{g})\end{array}$ & $\begin{array}{c}238 U \\
(p C i / g)\end{array}$ & $\begin{array}{c}232 \mathrm{Th} \\
(\mathrm{pCi} / \mathrm{g})\end{array}$ \\
\hline UT-1 & $1.84 \pm 0.02$ & 1.61 & 0.79 \\
\hline UT-2 & $1.42 \pm 0.02$ & 1.12 & 1.26 \\
\hline UT -3 & $1.03 \pm 0.03$ & 2.44 & 0.26 \\
\hline UT -4 & $1.59 \pm 0.05$ & 2.15 & 1.22 \\
\hline UT -5 & $1.10 \pm 0.04$ & 1.40 & 0.88 \\
\hline UT -6 & $1.76 \pm 0.05$ & 1.34 & 1.82 \\
\hline UT -7 & $2.05 \pm 0.05$ & 2.19 & 2.38 \\
\hline UT-8 & $1.76 \pm 0.04$ & 2.72 & 1.78 \\
\hline UT-9 & $1.07 \pm 0.03$ & 1.19 & 1.00 \\
\hline UT-10 & $1.72 \pm 0.05$ & 2.28 & 1.24 \\
\hline UT-11 & $1.40 \pm 0.03$ & 1.74 & 1.22 \\
\hline UT-12 & $1.53 \pm 0.06$ & 1.94 & 1.52 \\
\hline UT-13 & $1.12 \pm 0.03$ & 1.03 & 1.40 \\
\hline UT-14 & $1.74 \pm 0.04$ & $0: 80$ & 1.68 \\
\hline UT-15 & $1.65 \pm 0.04$ & 1.18 & 1.69 \\
\hline UT-16 & $1.70 \pm 0.05$ & 1.23 & 1.40 \\
\hline UT-17 & $1.35 \pm 0.04$ & 0.82 & 0.91 \\
\hline UT-18 & $1.55 \pm 0.05$ & 1.53 & 0.81 \\
\hline
\end{tabular}


from 0 to $2 \mathrm{~cm}$ in one set and $1.68 \pm 0.122 \mathrm{pCi} / \mathrm{g}$ from 0 to $9 \mathrm{~cm}$ in the other set. These values may be compared in a general way to our background measurements; see, for example, samples IIT-2 (1.42 $\pm 0.02 \mathrm{pC}, \mathrm{i} / \mathrm{q})$ and UT- $11(1.40 \pm 0.03 \mathrm{pCi} / \mathrm{g})$ in Table 3. Pendleton also presented, for these two sets of samples, ${ }^{232} \mathrm{Th}$ concentrations of $1.3 \mathrm{pCi} / \mathrm{g}$ and 1.5 $\mathrm{pCi} / \mathrm{g}$, respectively; we obtained concentrations of $1.26 \mathrm{pCi} / \mathrm{g}$ and 1.22 $\mathrm{pCi} / \mathrm{g}$ in our respective samples. A sample collected by Pendleton in April 1974 near the west side of the sewage treatment plant property at the Vitro site was at the approximate position of sample SS-52 in Fig. 4. He reported a ${ }^{226} \mathrm{Ra}$ concentration of $104.8 \mathrm{pCi} / \mathrm{g}$ from 0 to $2 \mathrm{~cm}$ whereas our results indicate $108 \mathrm{pCi} / \mathrm{g}$. In a second sample taken at the sewage treatment plant between two settling tanks, he reported $762 \mathrm{pCi} / \mathrm{q}$ from 0 to $2 \mathrm{~cm}$; and from this study (SS-51) a concentration of $570 \mathrm{pr} . \mathrm{i} / \mathrm{q}$ was found. The variation in this latter comparison is not surprising since it is unlikely that the samples were collected within 15 to $20 \mathrm{~m}$ of one another, and more than a year had elapsed between times of sample collection. The variability of radium activity in soil taken from areas lying close to the pile is discussed later in this chapter.

Background water samples were collected from four wells (see Fig. 9) located near the Vitro site, but at locations far enough off the sitep to be considered unaffected by the pile. The uranium and radium concentrations found in these samples are given in Table 4. Analyses were restricted to these radionuclides because uranium migrates at the fastest rate in groundwater and ${ }^{226} \mathrm{Ra}$ has the lowest $\mathrm{MPC}_{\mathrm{W}}{ }^{(37)}$ among the tailings 


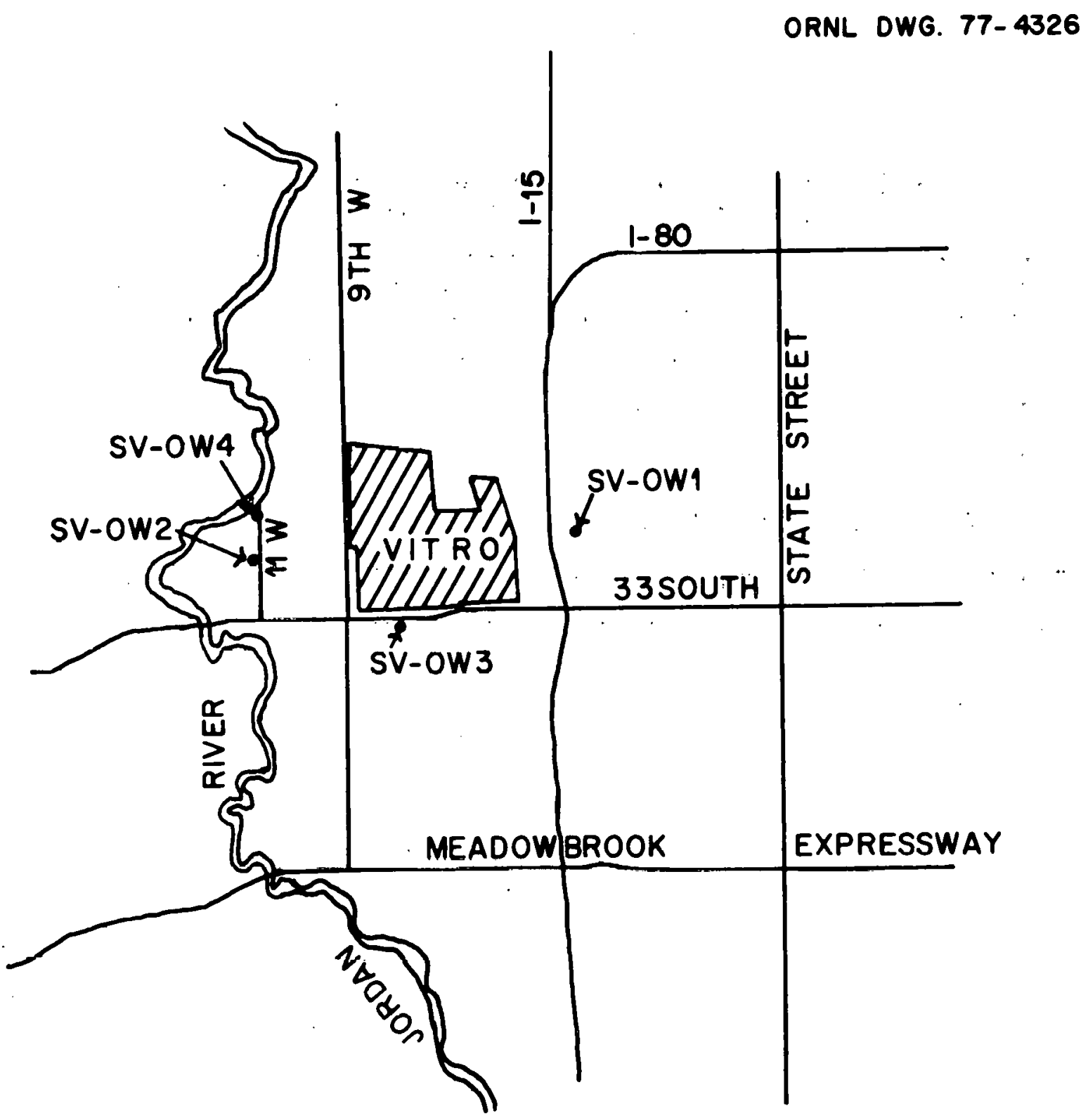

Fig. 9. Plan view of Vitro mill site showing location of water samples from private wells. 
48

Table 4. Radionuclide concentrations in well water near the Nitro site, Salt Lake City, Utah

\begin{tabular}{llcc}
\hline $\begin{array}{l}\text { Sample } \\
\text { number }\end{array}$ & Location of station & $\begin{array}{c}238 \mathrm{U} \\
\text { (pCi/liter) }\end{array}$ & $\begin{array}{c}226 \mathrm{Ra} \\
\text { (pCi/liter) }\end{array}$ \\
\hline SV-0W1 & 3106 South 400 West & 0.71 & 0.19 \\
SV-OW2 & 3200 South 1100 West & 0.22 & 0.08 \\
SV-0W3 & 837 West 3300 South & neg. & 0.48 \\
SV-OW4 & 3090 South 1100 West & 0.06 & 0.15 \\
\hline
\end{tabular}


components. Tanner ${ }^{(55)}$ has reported radium concentrations in water from wells in the Salt Lake Valley at locations remote from the Vitro site. These values ranged from $0.1 \mathrm{pCi} / 1$ iter to $2 \mathrm{pCi} / 1$ iter of $226 \mathrm{Ra}$.

Radioactivity in Groundwater in Tailings Pile

During the drilling operations at the Vitro site, it was observed that groundwater existed 3 to $4 \mathrm{ft}$ below the surface even in areas where the tailings surface was 15 or more $\mathrm{ft}$ higher than normal grade elevation. The overburden of tailings and the presence of an unconfined aquifer in the subsoil account for this shallow groundwater table. Samples were taken from the water present in each of the holes drilled into the tailings pile. Water was also collected from all surface streams. After centrifuging for removal of bulk solids, each sample was pressed through a $0.45-\mu \mathrm{m}$ filter. The water was then dispensed $(25 \mathrm{ml})$ into the previously described plastic scintillation counting vials, sealed, and stored for equilibration. The activity levels were so low that it was difficult to obtain statistically accurate estimates of the nuclides present by gamma-ray-spectroscopy techniques. Therefore, a composite sample was made up of one $25-\mathrm{ml}$ sample of water from each hole in the tailings pile. Radiochemical techniques were used to analyze this composite water sample. The results are given in Table 5. The level of radioactivity in flowing streams was indistinguishable from background.

A confined, artesian aquifer exists about $50 \mathrm{ft}$ below the base of the tailings pile. Because the piezometric surface of this aquifer is higher than grade elevation, groundwater flow is toward the surface. (4) 
Table 5. Radionuclide concentration in composite sample from groundwater in the Vitro tailings pile

\begin{tabular}{cc}
\hline Radionuclide & $\begin{array}{c}\text { Concentration } \\
\text { (pci/liter) }\end{array}$ \\
\hline $210 \mathrm{Po}$ & 10 \\
$230 \mathrm{Ra}$ & $\ldots \ldots 0$ \\
$238 \mathrm{U}$ & 5 \\
\hline
\end{tabular}


Horizontal movement of the surface aquifer is toward the Great Salt Lake at a hydraulic gradient of about $0.06 \%$ through a relatively impermeable

clay. ${ }^{(4)}$ Thus, minimal vertical and horizontal movement of the activities shown in Table 5 can be expected.

\section{Radionuclide Concentrations on the Site}

The Vitro site was divided into three general areas. Sampling locations in each area were used to obtain a profile of the gamma-ray intensity in the soil and, hence, a plot of the radium concentration as a function of depth below the surface. Typical radioactivity profiles are shown in Fig. 10 (note the interface between tailings and subsoil as indicated by an arrow). In some cases, it was possible to plot the measured concentration of uranium and radium at the same depth. It was noted earlier that an anionic uranyl complex may be expected to migrate more rapidly than radium, provided the groundwater is moving. Therefore, any noted imbalance of radium and uranium activities could indicate a preferential leaching of uranium. The interface between tailings and subsoil is detected easily, and its position may be estimated from the data in Fig. 10. However, some difficulties were encountered frequently in the insertion of a length of PVC tubing into the drilled holes. The possibility exists that some high specific activity tailings were brushed into the bottom of the hole or that the ever present groundwater washed some of the sandy textured material from upper levels into the bottom. It should also be pointed out that the split-spoon sampler used for sampling soil below the interface may have caused some side wall contamination into the sampling area. Therefore, we cannot place an estimate on the probable error in the position 


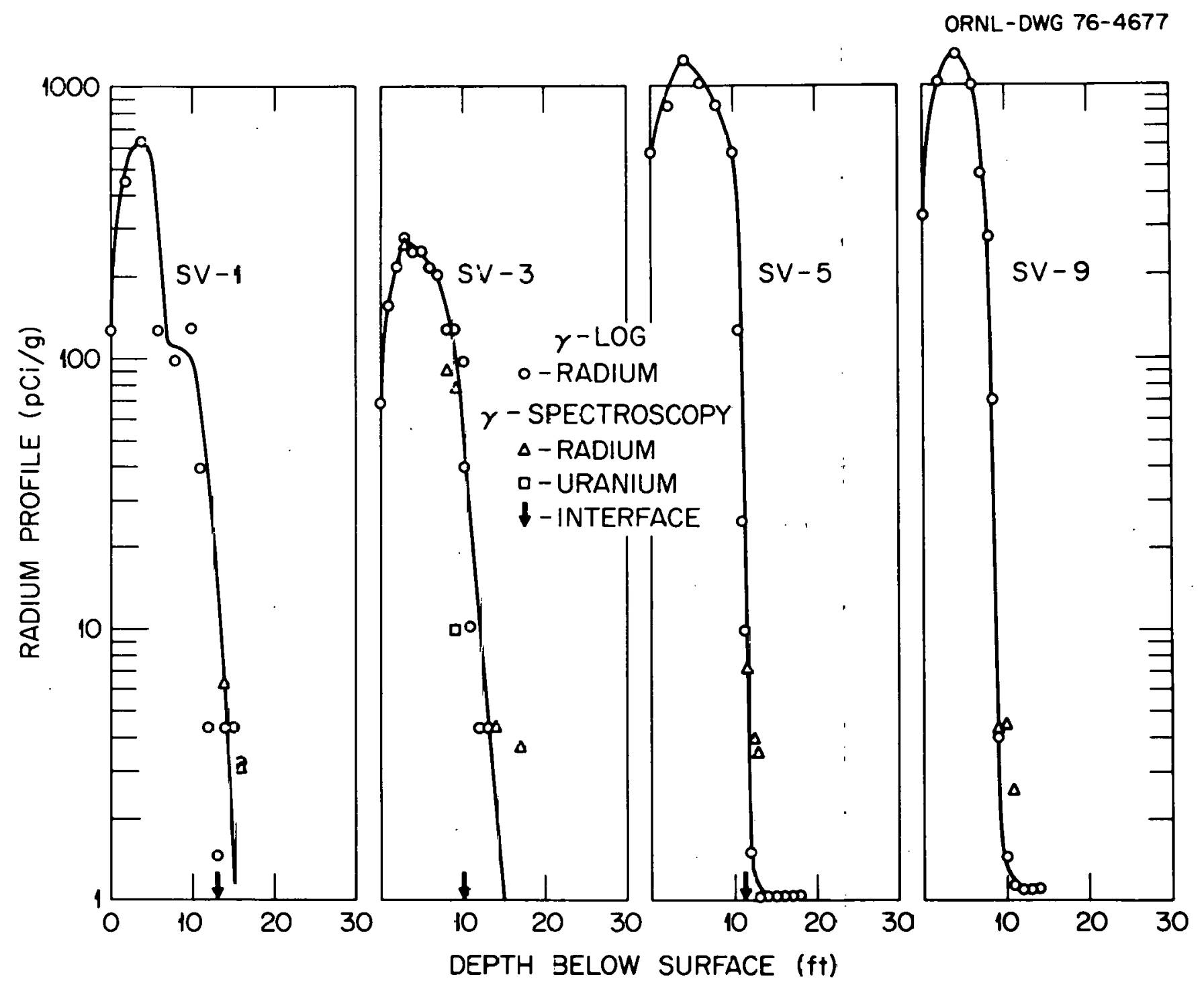

Fig. 10. Typical profile of ${ }^{226} \mathrm{Ra}$ concentration as a function of depth below the surface of Vitro tailirigs. 
of the interface or in the depth below the interface to which radium or uranium has leached. However, the downward migration of radionuclides is unlikely to be greater than that shown in Fig. 10 because the groundwater flow is toward the surface.

Radionuclide Concentrations off the Site

A series of soil samples was collected in areas away from the tailings pile to determine the spread of contamination due to wind and excessive runoff. This series included a set of 60 locations (1abeled in Fig. 4 as SS-1 through SS-60) at distances of 400 to $1000 \mathrm{~m}$ from the center of the Vitro site; soil was taken from the surface and at one foot below the surface. Also included in this series was a group of . sediment samples from the Jordan River, Mill Creek, and a drainage ditch used to carry effluent from the sewage treatment plant to the Jordan River.

Concentrations of ${ }^{226} \mathrm{Ra}$ in these surrounding site (SS) locations are presented in Table 6 . Some data are given for uranium concentrations. It is seen that some of the samples were taken from areas around the sewage treatment plant. On the west side of this site, some tailings material was used in construction. The rather high radium concentrations for samples SS-51 and SS-52 verify the presence of tailings in that area. In a number of locations, the radium concentration is greater at a depth of one foot than on the surface. This is an indication that the ground on which tailings were blown was disturbed after depostion, or that tailings were moved to that location and used in grading or construction. The results of these offsite analyses indicate that minimal activity is available for producing exposure through the terrestrial pathway. 
Table 6. 226 Ra concentration in soil collected off the site in areas surrounding the Vitro pile

\begin{tabular}{|c|c|c|c|c|c|c|c|}
\hline \multirow{3}{*}{$\frac{\begin{array}{c}\text { Sample } \\
\text { location }\end{array}}{\text { SS-1 }}$} & \multicolumn{2}{|c|}{$226 \mathrm{Ra}$ Concentration } & \multirow{3}{*}{$\begin{array}{c}\begin{array}{c}\text { Sample } \\
\text { location }\end{array} \\
\text { SS-31 }\end{array}$} & \multicolumn{4}{|c|}{$226 \mathrm{Ra}$ Concentration } \\
\hline & \multirow{2}{*}{$\begin{array}{c}\begin{array}{c}\text { Surface } \\
(\mathrm{pCi} / \mathrm{g})\end{array} \\
12.42 \pm 0.37\end{array}$} & $\begin{array}{c}\text { 12-in.deep } \\
(p c i / g)\end{array}$ & & \multicolumn{2}{|c|}{$\begin{array}{l}\text { Surface } \\
(\mathrm{pCi} / \mathrm{g})\end{array}$} & \multicolumn{2}{|c|}{$\begin{array}{c}\text { T2-in. deep } \\
(\mathrm{pci} / \mathrm{g})\end{array}$} \\
\hline & & & & $2.05 \pm$ & 0.08 & $20.3=$ & 0.47 \\
\hline SS-2 & $1.85 \pm 0.08$ & & SS-33 & $5.46 \pm$ & 0.16 & 1.22 & \pm 0.05 \\
\hline SS-3 & 2.50 & & SS-34 & $3.04 \pm$ & \pm 0.10 & 2.14 & \pm 0.07 \\
\hline SS-4 & $0.87 \pm 0.04$ & 4.1 & SS-35 & $1.43 \pm$ & \pm 0.06 & 2.23 & \pm 0.07 \\
\hline$S S=6$ & 34.2 & & SS:-36 & 0.82 & \pm 0.03 & 1.04 & \pm 0.06 \\
\hline $55-7$ & 1.6 & & 5S-37 & $35.93 \pm$ & 0.89 & 1.6 & 0.08 \\
\hline$S S-8$ & 11. & & $S S \cdots 38$ & $18.0 \pm$ & 0.44 & & \\
\hline SS-9 & 6.5 & & SS-39 & 45.6 & 1.04 & $22.23=$ & 0.51 \\
\hline SS-10 & 6. & 2.5 & SS-40 & 88.8 & 2.1 & 2.85 & 0.17 \\
\hline SS-11 & 3.44 & 2.44 & SS-41 & 37.6 & 0.94 & $67.4=$ & 1.62 \\
\hline SS-12 & 2.5 & 2.5 & SS -42 & $7.47 \pm$ & 0.27 & 2.38 & 0.10 \\
\hline SS-13 & $20.9 \pm 0.48$ & $2.42 \pm 0.08$ & SS -43 & $22.8 \pm$ & 0.51 & 5.66 & 0.21 \\
\hline SS-14 & $1.91 \pm 0.07$ & $6.6 \pm$ & SS-44 & $1.01 \pm$ & 0.05 & 1.06 & 0.05 \\
\hline SS-15 & $2.88 \pm 0.08$ & $5.6 \pm 0.16$ & SS-45 & $4.65 \pm$ & 0.13 & $1.81 \pm$ & 0.08 \\
\hline SS-16 & $7.34 \pm 0.02$ & $3.26 \pm 0.01$ & SS-46 & $13.3 \pm$ & 0.33 & $2.87 \pm$ & 0.11 \\
\hline SS-17 & $1.97 \pm 0.08$ & $1.37 \pm 0.05$ & SS-47 & 108.9 & 2.5 & $2.52 \pm$ & 0.10 \\
\hline SS-18 & $1.27 \pm 0.04$ & $1.06 \pm 0.06$ & SS -48 & 65.5 & \pm 1.6 & $7.72 \pm$ & 0.21 \\
\hline SS-19 & $1.56 \pm 0.05$ & $1.21+0.05$ & $S S=49$ & 65. & & $15.4 \pm$ & 0.45 \\
\hline SS-20 & $1.46 \pm 0.07$ & $1.33 \pm 0.05$ & SS-50 & 43.4 & \pm 1.0 & 18.4 & 0.45 \\
\hline SS-21 & $11.13 \pm 0.29$ & $289.3 \pm 6.45$ & SS-51 & 559.2 & \pm 12.5 & 465 & \pm 10.5 \\
\hline SS-22 & $7.37 \pm 0.19$ & $5.34 \pm 0.15$ & SS-52 & 110.1 & \pm 2.6 & 115.4 & \pm 2.6 \\
\hline SS-23 & $50.97 \pm 1.1$ & $1.85 \pm 0.06$ & $S . S-5.3$ & $4.52 \pm$ & \pm 0.12 & $6.99=$ & 0.18 \\
\hline SS-24 & $3.98 \pm 0.11$ & $1.26 \pm 0.05$ & SS-54 & $5.44 \pm$ & \pm 0.17 & $2.80 \pm$ & 0.09 \\
\hline SS-25 & 3 & $1.36 \pm 0.06$ & SS -55 & $11.9+$ & 0.3 & $8.7 \pm$ & 0.23 \\
\hline SS-26 & $10.72 \pm 0.28$ & $1.61 \pm 0.07$ & SS-56 & $1.93 \pm$ & 0.07 & $2.07 \pm$ & \pm 0.07 \\
\hline $53=27$ & 31 & $1.61 \pm 0.07$ & SS-57 & $2.08 \pm$ & 0.09 & $0.96 \pm$ & 0.04 \\
\hline $5 S-28$ & $12.9 \pm 0.31$ & $7.43 \pm 0.21$ & SS-58 & $151.3 \pm$ & 3.7 & $16.6 \pm$ & 0.45 \\
\hline SS-29 & $1.62 \pm 0.05$ & $1.15 \pm 0.04$ & SS-59 & $7.90 \pm$ & \pm 0.22 & $8.48 \pm$ & 0.23 \\
\hline SS-30 & $8.38 \pm 0.22$ & $2.52 \pm 0.09$ & SS-60 & $12.1 \pm$ & \pm 0.31 & $138.3 \pm$ & 3.3 \\
\hline
\end{tabular}

${ }^{a}$ No samples collected for locations SS-5 and SS-32. 
Radionuclide concentrations in waterway sediments are given in Table 7. These results show no indication of contamination in the Jordan River. The contamination present in the drainage ditch (particularly $230 \mathrm{Th}$ ) and in Mill (reek may be the result of previous liquid discharges from the mill. The absence of contamination in the surface water samples and in Jordan River sediments precludes the possibility of exposure through the aquatic pathway. Nevertheless, dredging of Mill Creek and the drainage ditch and proper disposal of the spoils may be a desirable remedial action.

There are several locations in Salt Lake City to which tailings have been moved for private use. These locations are discussed by Ford, Bacon and Davis, Utah, in their report of the Vitro site. (4) No results are presented here for measurements made at these locations. However, several commercial structures have been constructed in recent years along the east side of 900 West Street between 33rd South and the drainage ditch for the sewage treatment plant. Several holes were drilled through the concrete floors in these buildings and soil was collected at several depths (see Fig. 11). It was found that two of these structures had tailings under the floors. In one of these buildings, tailings ranged to at least $5 \mathrm{ft}$ deep. Results of measurements on samples collected under these buildings are given in Table 8 . The result of this type situation is a continuously elevated concentration of radon inside the building. During some periods of the day the radon progeny concentration may exceed 1 to 2 working levels (WL). For residences, the Surgeon General of the U.S. has recommended ${ }^{(3)}$ that the annual average working level concentration not exceed $0.01 \mathrm{WL}$. 
Table 7. Radionuclide concentration in sediment samples

\begin{tabular}{ccccc}
\hline & \multicolumn{4}{c}{ Concentration } \\
\cline { 2 - 5 } $\begin{array}{c}\text { Sample } \\
\text { number }\end{array}$ & $\begin{array}{r}226 \mathrm{Ra} \\
(\mathrm{pCi} / \mathrm{g})\end{array}$ & $\begin{array}{r}230 \mathrm{Th} \\
(\mathrm{pCi} / \mathrm{g})\end{array}$ & $\begin{array}{c}238 \mathrm{U} \\
(\mathrm{pCi} / \mathrm{g})\end{array}$ & $\begin{array}{c}210 \mathrm{~Pb} \\
(\mathrm{pCi} / \mathrm{g})\end{array}$ \\
\hline WJ-1 & 2.1 & 0.4 & 3.6 & 0.2 \\
W. -2 & 2.0 & 2.4 & 1.1 & 0.7 \\
WJ-3 & 0.9 & 0.6 & 2.1 & 0.3 \\
WJ-4 & 1.2 & 3.4 & 2.6 & 1.5 \\
& & & & \\
WD-1 & 51. & 221. & 33. & 95. \\
WD-2 & 67. & 18. & 182. & 7.5 \\
WD-3 & 51. & 18. & 41. & 7.8 \\
WD-4 & 116. & 284. & 129. & 122. \\
WD-5 & 6.5 & 6.3 & 6. & 2.4 \\
& & & & \\
WM-1 & 1.8 & 1.3 & 15 & 0.6 \\
WM-2 & 4.3 & 2.4 & 3.1 & 1.0 \\
WM-3 & 5.4 & 1.8 & 2.2 & 0.8 \\
WM-4 & 2.4 & 1.3 & 0.9 & 0.6 \\
WM-5 & 2.7 & 3.0 & 0.6 & 1.3 \\
& & & & \\
\hline
\end{tabular}


ORNL DWG. 77-4328

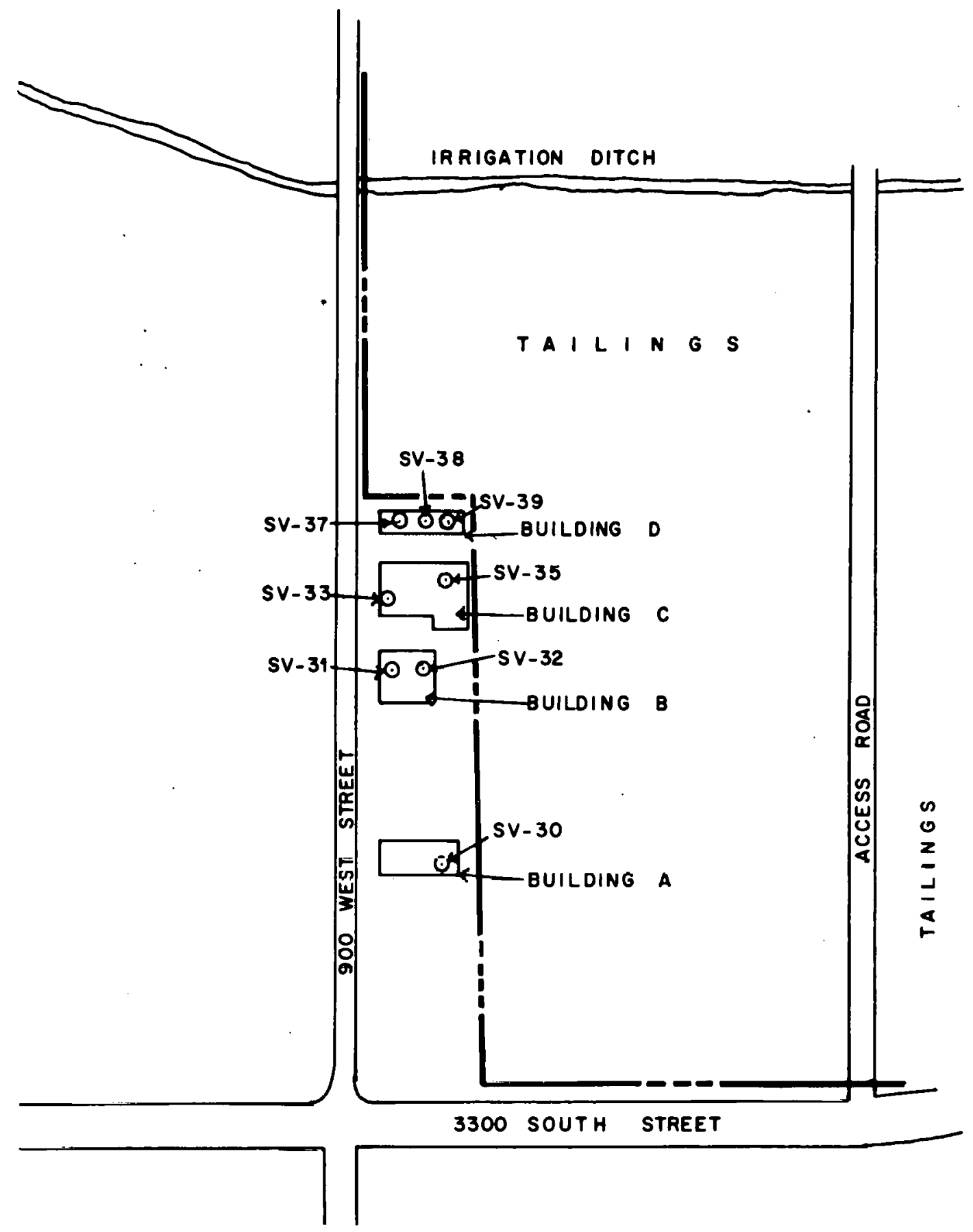

Fig. 11. Plot of southwest area of tailings pile showing the location of commercial structures along 900 West Street and the location of sampling points in these buildings. 
Table 8. ${ }^{226} \mathrm{Ra}$ concentration in soil beneath the floor of commercial structures along southwest edge of Vitro tailings pile

\begin{tabular}{|c|c|c|c|c|}
\hline Building & $\begin{array}{l}\text { Sample } \\
\text { location }\end{array}$ & $\begin{array}{c}\text { Depth } \\
\text { of sample } \\
\text { (in.) }\end{array}$ & ${ }^{226} \mathrm{Ra}$ & $\begin{array}{l}\text { concentration } \\
(\mathrm{pC} \mathrm{i} / \mathrm{g})\end{array}$ \\
\hline $\begin{array}{l}A \\
A \\
A\end{array}$ & $\begin{array}{l}\text { SV }-30 \\
\text { SV }-30 \\
\text { SV }-30\end{array}$ & $\begin{array}{r}12 \\
\cdot \quad 24 \\
36\end{array}$ & & $\begin{array}{l}1.07 \\
1.56 \\
2.20\end{array}$ \\
\hline $\begin{array}{l}B \\
B \\
B\end{array}$ & $\begin{array}{l}S V-31 \\
S V-31 \\
S V=31\end{array}$ & $\begin{array}{c}0-48 \\
60 \\
72\end{array}$ & & $\begin{array}{l}0.84 \\
2.82 \\
2.19\end{array}$ \\
\hline $\begin{array}{l}B \\
B \\
B \\
B\end{array}$ & $\begin{array}{l}S V-32 \\
S V-32 \\
S V-32 \\
S V-32\end{array}$ & $\begin{array}{c}n-48 \\
60 \\
72 \\
96\end{array}$ & & $\begin{array}{l}1.54 \\
3.35 \\
2.75 \\
2.28\end{array}$ \\
\hline $\begin{array}{l}c \\
c \\
c \\
c \\
c \\
c \\
c\end{array}$ & $\begin{array}{l}S V-33 \\
S V-33 \\
S V-33 \\
S V-33 \\
S V-33 \\
S V-33 \\
S V-33\end{array}$ & $\begin{array}{r}0-12 \\
12-16 \\
16-23 \\
23-29 \\
29-37 \\
37-50 \\
50-59\end{array}$ & & $\begin{array}{c}594 . \\
741 . \\
914 . \\
175 . \\
340 . \\
54 . \\
3 .\end{array}$ \\
\hline $\begin{array}{l}c \\
c \\
c \\
c\end{array}$ & $\begin{array}{l}\text { SV }-35 \\
\text { SV }-35 \\
\text { SV }-35 \\
\text { SV }-35\end{array}$ & $\begin{array}{c}0-12 \\
20 \\
30 \\
48-60\end{array}$ & & $\begin{array}{r}49 . \\
830 . \\
31 . \\
7.3\end{array}$ \\
\hline $\begin{array}{l}D \\
D \\
D\end{array}$ & $\begin{array}{l}\text { SV }-37 \\
\text { SV }-37 \\
\text { SV }-37\end{array}$ & $\begin{array}{r}0-12 \\
12=24 \\
36-48\end{array}$ & & $\begin{array}{l}1.39 \\
1.53 \\
1.64\end{array}$ \\
\hline $\begin{array}{l}D \\
D \\
D \\
D \\
D\end{array}$ & $\begin{array}{l}S V-38 \\
S V-38 \\
S V-38 \\
S V-38 \\
S V-38\end{array}$ & $\begin{array}{r}0-12 \\
12-24 \\
24-36 \\
36-48 \\
48-60\end{array}$ & & $\begin{array}{l}765 . \\
775 . \\
781 . \\
812 . \\
600 .\end{array}$ \\
\hline $\begin{array}{l}D \\
D \\
D \\
D \\
D\end{array}$ & $\begin{array}{l}\text { SV }-39 \\
\text { SV-39 } \\
\text { SV }-39 \\
\text { SV-39 } \\
\text { SV }-39\end{array}$ & $\begin{array}{c}0-12 \\
12-24 \\
24-36 \\
36-48 \\
48\end{array}$ & & $\begin{array}{l}770 . \\
730 . \\
800 . \\
810 . \\
590 .\end{array}$ \\
\hline
\end{tabular}


Elemental Composition of Material from the Vitro Tailings Pile

A total of 12 samples of tailings material were gathered at random locations on the pile. These samples were analyzed by the ORNL Analytical Chemistry Division utilizing a spark-source mass spectrometer. A semiquantitative analysis ( \pm factor of 2 ) was requested to determine if potentially hazardous or toxic materials were present in significant quantities. The elemental concentrations in these samples are given in Table 9 for those elements whose wt. \% exceeded 0.05. After this analys is had been completed, a question was raised about the concentration of arsenic, selenium, and uranium. Because of analytical costs, a composite was formed of these 12 samples and one additional analysis was made. The concentration of arsenic was $0.03 \%$, selenium was $0.003 \%$, and uranium was $0.03 \%$.

Direct Gamma-Ray Exposure Rates On and Near the Tailings Pile

The direct gamma-ray exposure around most of the inactive uranium mills does not constitute a significant hazard because of the fact that most of these sites are in secluded areas. However, there are some notable exceptions, such as the Vitro site, where a large population group resides near the pile. It was decided to calculate the potential health effects from direct gamma exposure; thus, a series of measurements were made at each place a soil sample had been taken and at locations near the pile and along public roads. Gamma-ray exposure as a function of distance from the center of the pile (sample point SV-15) is plotted in Fig. 12. There is a reduction of exposure rate with distance; however, the relationship does not follow the inverse square law because of the large physical size of the pile. 
Table 9. Elemental composition of material from the Vitro tailings pile (Listed values are wt.\% if greater than 0.05 )

\begin{tabular}{|c|c|c|c|c|c|c|c|c|c|c|c|c|}
\hline \multirow{2}{*}{ Element } & \multicolumn{12}{|c|}{ Random sample numbers } \\
\hline & 1 & 2 & 3 & 4 & 5 & 6 & $?$ & 8 & 9 & 10 & 11 & 12 \\
\hline $\mathrm{Ca}$ & 0.5 & 5. & 0.1 & 7.5 & 0.6 & 1 & 5. & 5. & $>5$. & 0.7 & 5. & $>5$ \\
\hline $\mathrm{Cu}$ & - & - & - & - & - & - & - & - & - & - & - & 0.15 \\
\hline $\mathrm{Fe}$ & 0.7 & 1. & 1. & 0.9 & 0.9 & 1. & 1.5 & 1. & 1. & 4. & $\geq 5$ & $\geq 5$ \\
\hline $\mathrm{Mg}$ & 0.5 & 0.8 & C.1 & 1 & 0.4 & 0.8 & 5. & 3. & 2. & 1. & 0.8 & 0.8 \\
\hline Mn & - & - & - & 0.1 & - & - & 0.1 & - & - & 0.09 & 0.2 & 0.7 \\
\hline Mo & - & - & - & - & - & 0.1 & - & - & - & 0.09 & - & 0.06 \\
\hline $\mathrm{Na}$ & 0.8 & 0.3 & 2. & 0.4 & 1. & 1. & 2. & 1. & 0.6 & 1.5 & 0.7 & 0.9 \\
\hline $\mathrm{Ni}$ & - & - & - & - & - & - & - & - & - & - & 0.09 & $0.1+$ \\
\hline $\mathrm{Ti}$ & 0.05 & 0.3 & 0.08 & 0.3 & 0.07 & 0.3 & 0.2 & 0.15 & 0.2 & 0.4 & 0.2 & 0.15 \\
\hline$v$ & - & - & - & - & - & - & - & - & C.075 & - & 0.15 & 0.5 \\
\hline $\mathrm{Zn}$ & 0.05 & 0.06 & 0.05 & 0.05 & - & 0.06 & 0.06 & 0.05 & - & 0.15 & 0.09 & 0.1 \\
\hline
\end{tabular}




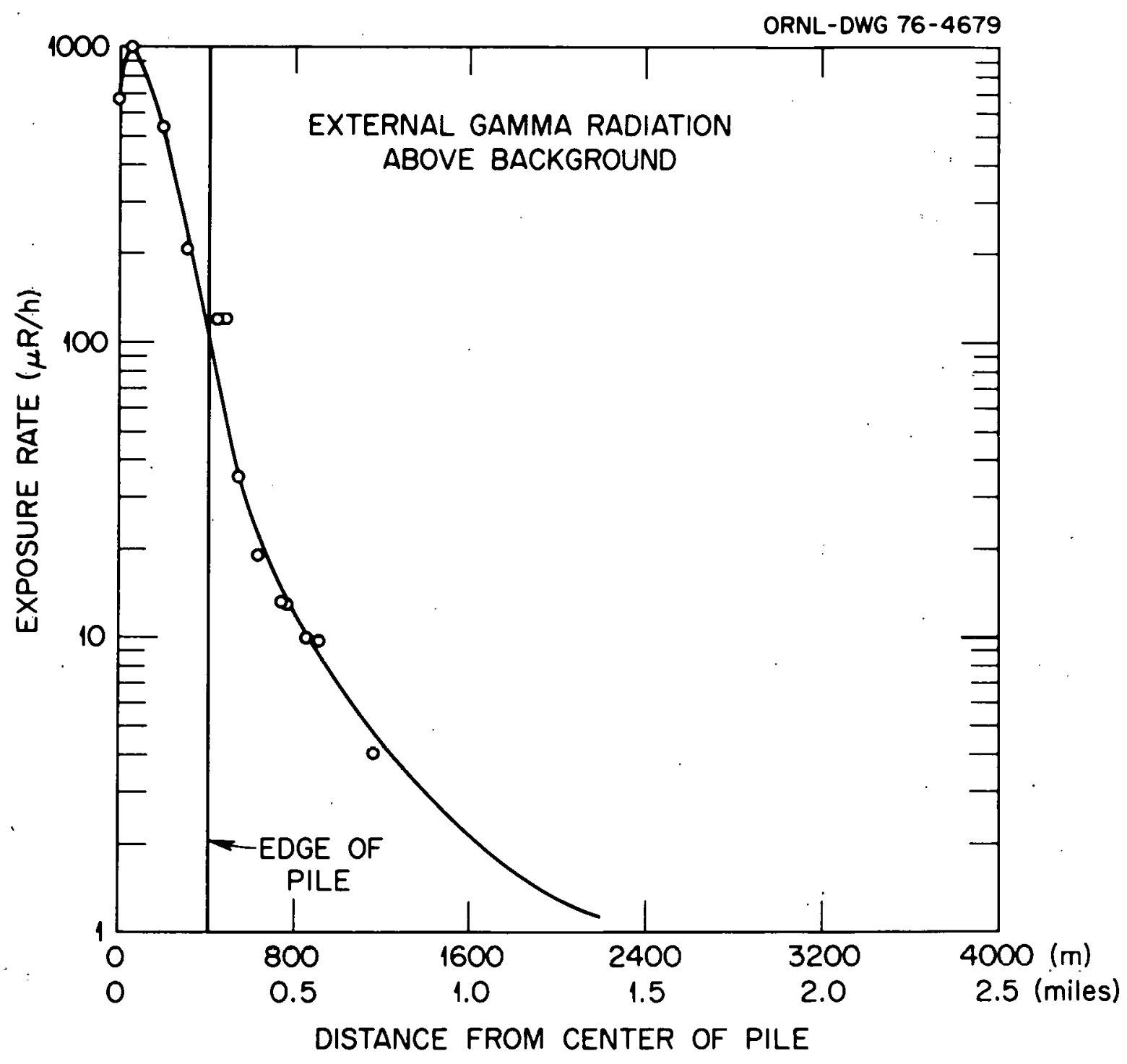

Fig. 12. External gamma radiation $(\mu \mathrm{R} / \mathrm{hr})$ as a function of distance from the center of the Vitro tailings pile. 
Gamma-ray measurements were also made inside three of the commercial structures shown in Fig. 11. These levels are listed in Table 10. In building $A$, it is observed that the level is just over $200 \mu R / h r$. For persons working in this building for a period of 40 hours per week for 50 weeks per year, the integrated exposure is $400 \mathrm{mrem} / \mathrm{year}$.

Radon and Radon Daughter Concentration in Structures

During the course of this study, a series of radon and radon daughter samples were taken in the sewage treatment plant office building, several commercial buildings located near the pile, and in some residences. Measurements of radon concentrations were made by others and are given in reference (4). In most cases, air was sampled for radon with a Lucas chamber at the same time air was sampled for radon daughters. Given radon and radon progeny concentrations, one can determine the degree of equilibrium between radon and its daughters. A ratio of the activity of each successive daughter in the chain gives some information about the ventilation rate for the structure and permits the calculation of the working level concentration in that area. It should be pointed out that in a short period of time (such as the period of this investigation), the only physical measurements of significance are those which are nonvarying. Mcasurcments of radon and/or radon progeny concentrations made continuously for a short period ( $\leq 30$ days) are insufficient for use in evaluating the radon exposure conditions over a long period (i.e. $\geq 1$ year). Annual average concentrations require a knowledge of the seasonal variation in the distribution of values. The results of spot sampling for the concentration of radon daughters are presented in Table 11 for 
Table 10. Gamma-ray exposure rates inside commercial structures along southwest edge of Vitro tailings pile

\begin{tabular}{clc}
\hline Building & Location of measurement & $\begin{array}{c}\text { Exposure } \\
(\mu \mathrm{R} / \mathrm{hr})\end{array}$ \\
\hline B & 10 ft from rear door & 40. \\
B & Near front entrance & 26.4 \\
B & Near center of building & 28.4 \\
& & \\
C & In storage room & 104. \\
C & 25 ft from east wall & 191. \\
C & Near center of building & 98. \\
& & 34.7 \\
D & Near front office & 219. \\
\hline
\end{tabular}


Table 11. Concertration of radon and radon daughters

\begin{tabular}{|c|c|c|c|c|c|c|c|c|c|c|c|c|}
\hline \multirow[b]{2}{*}{$\begin{array}{l}\text { Date } \\
1975\end{array}$} & \multirow[b]{2}{*}{ Time } & \multicolumn{6}{|c|}{ Consentration } & \multirow[b]{2}{*}{$\begin{array}{l}\text { Working } \\
\text { levels } \\
(W L)^{5}\end{array}$} & \multirow[b]{2}{*}{$\begin{array}{c}\% \\
\text { Equil. }\end{array}$} & \multirow[b]{2}{*}{$\frac{\operatorname{RaA}}{\mathrm{Rn}}$} & \multirow[b]{2}{*}{$\frac{\mathrm{RaB}}{\mathrm{Rn}}$} & \multirow[b]{2}{*}{$\frac{\operatorname{RaC}}{\mathrm{Rn}}$} \\
\hline & & Location & $\begin{array}{c}2 n \\
(p C i / / \text { iter })\end{array}$ & $\begin{array}{c}\operatorname{RaA} \\
(\mathrm{pC} i / 1 \text { iter })\end{array}$ & $\begin{array}{c}\mathrm{R}^{3 B} \\
(\mathrm{pC} \cdot \mathrm{C} / \mathrm{i} \text { iter })\end{array}$ & $\begin{array}{c}\mathrm{RaC} \\
(\mathrm{pC} \text { i/liter })\end{array}$ & $\begin{array}{l}\text { Total } \\
\text { daughters } \\
\text { (pcijifiter) }\end{array}$ & & & & & \\
\hline $\begin{array}{l}9-25 \\
9-26\end{array}$ & $\begin{array}{l}11: 00 \\
10: 40\end{array}$ & Outside, 1745 S. Redwood & & $\begin{array}{l}0.43(19) \\
0.96(14)\end{array}$ & $\begin{array}{l}0.23(36) \\
0.17(75)\end{array}$ & $\begin{array}{l}0.17(34) \\
0.46(20)\end{array}$ & $\begin{array}{l}0.83(53) \\
1.58(78)\end{array}$ & $\begin{array}{l}0.0022 \\
0.004\end{array}$ & & & & \\
\hline $\begin{array}{l}9-26 \\
9-26 \\
10-2 \\
10-2 \\
10-2\end{array}$ & $\begin{array}{l}14: 40 \\
14: 40 \\
09: 35 \\
11: 55 \\
16: 10\end{array}$ & $\begin{array}{c}\text { Sewage treatment plant } \\
\text { Southwest room } \\
" " \\
"\end{array}$ & & $\begin{array}{l}0.78(15) \\
0.6(17) \\
3.19(9) \\
2.31(10) \\
1.02(13)\end{array}$ & $\begin{array}{ll}0.5 & (26) \\
0.3) & (34) \\
2.75 & (23) \\
1.8 .5 & (25) \\
0.5 & (34)\end{array}$ & $\begin{array}{l}0.26(35) \\
0.19(35) \\
2.11(20) \\
1.67(19) \\
0.6(21)\end{array}$ & $\begin{array}{l}1.56(46) \\
1.09(52) \\
8.07(32) \\
5.83(33) \\
2.18(42)\end{array}$ & $\begin{array}{l}0.0044 \\
0.0028 \\
0.025 \\
0.018 \\
0.0061\end{array}$ & & & & \\
\hline $\begin{array}{l}9-26 \\
10-1 \\
10-1\end{array}$ & $\begin{array}{l}11: 25 \\
09: 43 \\
16: 05\end{array}$ & $\begin{array}{c}\text { Bldg. } \text {, Fig. }_{11} \text {, store rocm } \\
\text { (1) }\end{array}$ & 195. & $\begin{array}{ll}132 . & (6) \\
139 . & (6) \\
372 . & (6)\end{array}$ & $\begin{array}{rr}77 . & (21) \\
108 . & (19) \\
179 . & (22)\end{array}$ & $\begin{array}{cc}63.21 & (5) \\
61.1 & (22) \\
130 . & (20)\end{array}$ & $\begin{array}{ll}272 . & (27) \\
308 . & (29) \\
681 . & (30)\end{array}$ & $\begin{array}{l}0.76 \\
0.92 \\
1.77\end{array}$ & $\begin{array}{l}39 \\
32\end{array}$ & $\begin{array}{l}0.68 \\
0.67\end{array}$ & $\begin{array}{l}0.39 \\
0.32\end{array}$ & $\begin{array}{l}0.32 \\
0.23\end{array}$ \\
\hline $\begin{array}{l}9-26 \\
9-26 \\
10-1 \\
10-1 \\
10-1 \\
10-1 \\
10-1\end{array}$ & $\begin{array}{l}13: 00 \\
13: 40 \\
10: 22 \\
11: 22 \\
14: 50 \\
15: 30 \\
17: 10\end{array}$ & $\begin{array}{c}\text { Bldg. D, Fig. 11, shop } \\
" 1 \\
" \\
" \\
"\end{array}$ & $\begin{array}{l}76.8 \\
\\
6.95 \\
16.2 \\
81.3\end{array}$ & $\begin{array}{l}49.1 \quad(6) \\
16.4(7) \\
2.17(10) \\
4.94(3) \\
9.46(7) \\
6.38(3) \\
43.6(5)\end{array}$ & $\begin{array}{cc}32.8 & (23) \\
6.7 & (25) \\
0.4 & (38) \\
0.9 & (27) \\
1.76 & (24) \\
1.16 & (26) \\
11.3 & (20)\end{array}$ & $\begin{array}{cc}29 . & (18) \\
5.9 & (19) \\
0.4 & (27) \\
0.4 & (40) \\
0.8 & (34) \\
0.6 & (34) \\
4.22 & (32)\end{array}$ & 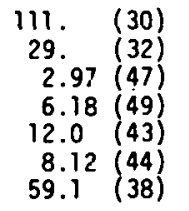 & $\begin{array}{l}0.32 \\
0.073^{\mathrm{a}} \\
0.0057^{\mathrm{b}} \\
0.011 \mathrm{~b} \\
0.02 \mathrm{~b}^{\mathrm{b}} \\
0.015^{\mathrm{b}} \\
0.12^{\mathrm{c}}\end{array}$ & $\begin{array}{l}16 \\
13 \\
15\end{array}$ & $\begin{array}{l}0.71 \\
0.58 \\
0.54\end{array}$ & $\begin{array}{l}0.12 \\
0.11\end{array}$ & $\begin{array}{l}0.06 \\
0.05 \\
0.05\end{array}$ \\
\hline $\begin{array}{l}9-26 \\
9-26\end{array}$ & $\begin{array}{l}16: 50 \\
17: 30\end{array}$ & $\begin{array}{c}3226 \mathrm{~W} .300 \mathrm{~W} \cdot \mathrm{nside} \\
\text { autside }\end{array}$ & & $\begin{array}{l}0.28(24) \\
0.34(23)\end{array}$ & $\begin{array}{l}0.06(93) \\
0.10(46)\end{array}$ & $\begin{array}{l}0.11(34) \\
0.05(77)\end{array}$ & $\begin{array}{l}0.45 .102) \\
0.48(93)\end{array}$ & $\begin{array}{l}0.001 \\
0.001\end{array}$ & & : & & \\
\hline $9-26$ & $18: 35$ & 363 W. 33rd S. front roon & & $1.54(11)$ & $0.45 \cdot(31)$ & $0.36(28)$ & $2.39(43)$ & 0.0054 & & & & \\
\hline $\begin{array}{l}9-27 \\
9-27 \\
9-27\end{array}$ & $\begin{array}{l}09: 00 \\
10: 45 \\
11: 20\end{array}$ & $\begin{array}{c}\text { Bldg. B,Fig.11. store rcem } \\
\text { " } \quad \text { outside }\end{array}$ & & $\begin{array}{l}13.2(7) \\
7.66(7) \\
2.13(10)\end{array}$ & $\begin{array}{l}9.8 c(22) \\
5.2 E(28) \\
1.6 \epsilon(24)\end{array}$ & $\begin{array}{l}7.83(19) \\
6.18(16) \\
1.33(21)\end{array}$ & $\begin{array}{cc}30.8 & (30) \\
19.1 & 33) \\
5.13 & (34)\end{array}$ & $\begin{array}{l}0.092 \\
10.057 \\
10.016\end{array}$ & & & & \\
\hline $9-29$ & $12: 15$ & Bidg. A,Fig.11. outside & & $0.68(16)$ & $0.0 \bar{\varepsilon}(283)$ & $0.19(26)$ & $0.9 .284)$ & 0.0015 & & & & \\
\hline $\begin{array}{l}9-29 \\
9-29 \\
9-29\end{array}$ & $\begin{array}{l}14: 10 \\
14.50 \\
15: 25\end{array}$ & $\begin{array}{c}\cdot 738 \text { E } 1930 \mathrm{~S} \text {, basement } \\
" \text { oLtside roor }\end{array}$ & & $\begin{array}{l}0.38(21) \\
0.61(1 ?) \\
0.4 \quad(2 \%)\end{array}$ & $\begin{array}{l}0.0 \subseteq(68) \\
0.0 E(107)\end{array}$ & $\begin{array}{l}0.14(33) \\
0.17(29) \\
0.1 \quad(26)\end{array}$ & $\begin{array}{l}0.6(78) \\
0.8 \cdot 112) \\
0.4 \quad(74)\end{array}$ & $\begin{array}{l}0.0014 \\
0.0015 \\
0.0005\end{array}$ & & & & \\
\hline $\begin{array}{l}9-29 \\
9-29\end{array}$ & $\begin{array}{l}16: 45 \\
17: 20\end{array}$ & G.C. warehouse & 6.56 & $\begin{array}{ll}0.9 & (14) \\
0.8 & (16)\end{array}$ & $\begin{array}{l}0.07(28) \\
0.6 \quad(30)\end{array}$ & $\begin{array}{ll}0.6 & (23) \\
0.5 & (24)\end{array}$ & $\begin{array}{l}2.27(39) \\
1.86(41)\end{array}$ & $\begin{array}{l}0.0069^{d} \\
0.0057\end{array}$ & 11 & 0.14 & 0.11 & 0.09 \\
\hline
\end{tabular}

aoor opened approxinately orie hour prior to measurement.

boors open.

cSample collected 30 minutes after shop closed.

$\mathrm{d}_{\text {Near open door. }}$ 
several locations near the tailings pile. Only very tentative conclusions may be drawn from these data because of the short-term nature of the measurements. It is possible, however, to observe the disequilibrium which exists between $\mathrm{RaA}, \mathrm{RaB}$, and $\mathrm{RaC}$ and in some cases between these nuclides and $\mathrm{Rn}$.

Calculation of ${ }^{222} \mathrm{Rn}$ Emanation and Dispersion From the Tailings Pile Average ${ }^{226} \mathrm{Ra}$ concentrations in tailings were determined from aamma logs and $y$ spectroscopy for each of the test holes SV-l thru SV-29. The representative samples shown in Table 12 were then averaged to estimate the overall average ${ }^{226} \mathrm{Ra}$ content of the pile as $460 \mathrm{pCi} / \mathrm{g}$. The average depth of contamination was estimated to be $13 \mathrm{ft}$. The contaminated area was estimated from a large scale drawing of Fig. 4 as approximately 117 acres $\left(4.7 \times 10^{5} \mathrm{~m}^{2}\right)$. Assuming that the specific gravity of the tailings material is $1.6 \mathrm{~g} / \mathrm{cm}^{3},(10,56)$ the total ${ }^{226} \mathrm{Ra}$ inventory may be calculated as $1400 \mathrm{Ci}$ which compares favorably with the estimate of 1380 $\mathrm{Ci}$ based on the assays of ore processed by the Vitro mill. (3)

The estimated mass of coritaminated material, $3.3 \times 10^{6}$ tons, is almost double the amount of uranium ore processed by the mill, $1.7 \times 10^{6}$ tons. (3) The additional mass includes an undetermined volume of lowactivity vanadium tailings mixed with and piled upon the uranium tailings, the contaminated soil beneath the tailings piles and the ore storage area, and a large quaritity of sewage sludge.

Emanation of ${ }^{22} \mathrm{Rn}$ from the surface of the Vitro pile was estimated by use of Eq. (1) in Chapter 3 of this report. Porosity was assumed to be $0.4,(10,55)$ specific gravity $1.6 \mathrm{~g} / \mathrm{cm}^{3},(10,56)$ bulk diffusion 
Table 12. Determination of average ${ }^{226} \mathrm{Ra}$ concentration of Vitro tailings pile

\begin{tabular}{|c|c|c|}
\hline $\begin{array}{c}\text { Hole } \\
\text { number }\end{array}$ & $\begin{array}{c}{ }^{226} \mathrm{Ra} \\
(\mathrm{pCi} / \mathrm{g})\end{array}$ & $\begin{array}{l}\text { Depth } \\
(\mathrm{ft})\end{array}$ \\
\hline SV- 1 & 180 & 16 \\
\hline SV -2 & 170 & 16 \\
\hline SV -3 & 140 & 14 \\
\hline$S V-4$ & 580 & 13 \\
\hline$S V-5$ & 790 & 12 \\
\hline SV- 8 & 100 & 5 \\
\hline SV- 9 & 760 & 10 \\
\hline SV-10 & 720 & 14 \\
\hline SV-12 & 600 & 18 \\
\hline SV -13 & 550 & 23 \\
\hline SV-14 & 260 & 21 \\
\hline SV-15 & 360 & 17 \\
\hline SV-16 & 990 & 5 \\
\hline SV-17 & 940 & 5 \\
\hline $5 V-18$ & 1570 & 12 \\
\hline SV-19 & 290 & 5 \\
\hline SV-20 & 280 & 10 \\
\hline$S V-21$ & 170 & 12 \\
\hline SV-22 & 140 & 12 \\
\hline SV-23 & 170 & 3 \\
\hline SV -25 & 180 & 18 \\
\hline SV-26 & 640 & 12 \\
\hline SV -27 & 90 & 17 \\
\hline SV-28 & 310 & 11 \\
\hline Average & 460 & 13 \\
\hline
\end{tabular}


coefficient $0.028 \mathrm{~cm}^{2} / \mathrm{sec}$ (equivalent to that observed for sand $00 \%$ moisture ${ }^{(18)}$ ), and emanation fraction 0.2 as discussed in Chapter 3. Diffusion properties of the subsoil were assumed to be similar to those for water-saturated clay. (18) These assumptions coupled with an average ${ }^{226} \mathrm{Ra}$ content of $460 \mathrm{pCi} / \mathrm{g}$ and an average depth of $13 \mathrm{ft}$. yielded a ${ }^{222} \mathrm{Rn}$ emanation rate of $550 \mathrm{pCi} / \mathrm{m}^{2}$-sec.

Radon emanation rates have been measured at various locations on the Vitro tailings pile. ${ }^{(57)}$ The average of these short-term measurements was $320 \mathrm{pCi} / \mathrm{m}^{2}-\mathrm{sec}$. This measured value is only about $60 \%$ of the calculated value. However, the physical descriptions of the measured sites imply that the radon emanation rate from the ore storage area was not measured. This is the area containing the highes $t$ concentration of ${ }^{226} \mathrm{Ra}$ contamination. Furthermore, all assumptions related to the calculated emanation rate were made to maximize computed results. Thus, the calculated emanation rate of $550 \mathrm{pCi} / \mathrm{m}^{2}-\mathrm{sec}$ should be a conservative estimate of the annual average.

An area source model ${ }^{(21)}$ was used in conjunction with the most recent wind profile and stability data for Salt Lake City $(58)$ to estimate the outdoor ${ }^{222} \mathrm{Rn}$ concentrations attributable to the tailings pile. Results of dispersion calculations for an area source strength of $2.6 \times$ $10^{8} \mathrm{pCi} / \mathrm{sec}$ are shown in Table 13. The horizontal lines on Table 13 correspond to distances at which the ${ }^{222} \mathrm{Rn}$ concentration attributable to the tailings pile is approximately equal to background $(0.38 \mathrm{pCi} / 1 \mathrm{iter})^{(26)}$ and $10 \%$ of background. As may be seen from Table 13, radon attributable to the tailings pile is about $10 \%$ of background at a distance of 2 miles 
Table 13. ${ }^{222} \mathrm{Rn}$ concentration ( $\mathrm{pC} / \mathrm{l} / \mathrm{iter}$ ) resulting from the Vitro tailings pile

\begin{tabular}{|c|c|c|c|c|c|c|c|c|c|c|c|c|c|c|c|c|}
\hline \multirow{2}{*}{$\begin{array}{c}\text { Dist. from } \\
\text { edge of } \\
\text { pile } \\
\text { (mile) }\end{array}$} & \multirow{2}{*}{$\frac{m}{N}$} & \multirow[b]{2}{*}{ NNE: } & \multirow[b]{2}{*}{ NE } & & \multirow[b]{2}{*}{ SE } & \multicolumn{3}{|c|}{ Compass direction } & \multirow[b]{2}{*}{ SW } & \multirow[b]{2}{*}{ WSW } & \multirow[b]{2}{*}{$W$} & \multirow[b]{2}{*}{ WNW } & $\cdot$ & \multirow[b]{2}{*}{ NNW } \\
\hline & & & & ENE & $\mathbf{E}$ & ESE & & SSE & $S$ & SSW & & & & & NW & \\
\hline 0 & 4.1 & 3.1 & 2.3 & 1.5 & 1.7 & 1.8 & 2.4 & 2.4 & 2.3 & 2.1 & 1.7 & 1.2 & 1.7 & 2.6 & 4.1 & 4.5 \\
\hline 0.25 & 1.2 & 0.72 & 0.37 & 0.36 & 0.42 & 0.47 & 0.45 & 0.64 & 0.72 & 0.58 & 0.31 & 0.21 & 0.27 & 0.57 & 1.1 & 1.4 \\
\hline 0.50 & 0.68 & 0.27 & 0.17 & 0.16 & 0.21 & 0.23 & 0.22 & 0.28 & 0.40 & 0.27 & 0.15 & 0.09 & 0.13 & 0.25 & 0.54 & 0.70 \\
\hline 0.75 & 0.46 & 0.12 & נ] & 0.95 & 0.13 & 0.73 & 0.13 & 0.15 & 0.28 & 0.14 & _.09. & 0.05 & 0.08 & 0.13 & 0.33 & 0.42 \\
\hline 1.75 & 0.15 & 0.04 & 0.03 & 0.03 & 0.04 & 0.04 & 0.04 & -0.05 & 0.09 & لـ & 0.02 & 0.01 & 0.02 & -0.04 & 0.10 & 0.13 \\
\hline 2.75 & 0.08 & 0.02 & $0.0 ?$ & 0.01 & 0.02 & 0.02 & 0.02 & $0.02 \vdots$ & j & 0.02 & 0.01 & 0.007 & 0.01 & $0.02:$ & 0.05 & 0.07 \\
\hline 3.75 & 0.05 & 0.01 & 0.01 & 0.009 & 0.01 & 0.01 & 0.01 & 0.01 & 0.03 & 0.001 & 0.009 & 0.004 & 0.007 & 0.01 & 0.03 & 0.04 \\
\hline 4.75 & 0.03 & 0.003 & 0.038 & 0.006 & 0.009 & 0.009 & 0.01 & 0.009 & 0.02 & 0.009 & $0.00 €$ & 0.003 & 0.005 & 0.009 & 0.02 & 0.03 \\
\hline 6.75 & 0.02 & $0.00 \Xi$ & 0.034 & 0.004 & 0.005 & 0.006 & 0.005 & 0.006 & 0.01 & 0.006 & $0.00<$ & 0.002 & 0.003 & 0.005 & 0.01 & 0.02 \\
\hline
\end{tabular}

NOTE: _Pile contribution ^ background.

-.-.-.- Pile contribution $\cong 10 \%$ of background. 
from the tailings pile in all but 4 sectors. Radon concentration decreases to $10 \%$ of background in all directions at about 4 miles from the pile.

A comparison of calculated and measured annual ${ }^{222} \mathrm{Rn}$ concentrations is shown in Table 14. Good agreement was obtained at all points except Shearer and Sill's ${ }^{(26)}$ station number 83 . The sampling location map given by Shearer and Sill(26) indicates that this station was located on 3300 South across the street from the tailings pile.

Atmospheric dispersion of ${ }^{222} \mathrm{Rn}$ attributable to the tailings pile was calculated for a distance of 7 miles from the center of the pile in 16 compass directions. The area included in this 7 mile radius is shown in Fig. 13. Extrapolations beyond this distance involve concentrations approaching $1 \%$ of background and would affect a small percentage of the metropolitan population. Furthermore, the presence of mountain ranges at distances beyond 7 miles would invalidate the turbulent diffusion model used to perform the calculations.

It was assumed that no ${ }^{222 R n}$ was lost between the source and the receptor by decay, rainout, or dry deposition. Thus, the concentrations shown in Table 13 are conservative estimates of annual averages.

\section{Concentrations of Airborne Radionuclides}

Results of an air sampling program conducted by the USEPA are given in Table 15. The average concentration was determined from 26 consecutive samples of two weeks duration each. The air sampler was located at the Suburban Sewage Treatment Plant which is located about 0.1 mile north of the largest tailings area. The STAR wind profile analysis. ${ }^{(58)}$ indicates that winds with velocity $>18 \mathrm{mph}(>41 \mathrm{~m} / \mathrm{sec}$ ) 
Table 14. Comparison of calculated and measured $222 \mathrm{Rn}$ concentrations in Salt Lake City

\begin{tabular}{|c|c|c|}
\hline $\begin{array}{l}\text { Station } \\
\text { number }\end{array}$ & $\begin{array}{l}\text { Measured }{ }^{\mathrm{a}} \\
\text { (pCi/liter) }\end{array}$ & $\begin{array}{l}\text { Calculated } \\
\text { (pci/liter) }\end{array}$ \\
\hline 83 & $0.43+0.31$ & $2 . F_{1} \pm 0.4$ \\
\hline 84 & $0.39 \pm 0.24$ & $0.59 \pm 0.26$ \\
\hline 85 & $0.68 \pm 0.30$ & $0.84 \pm 0.27$ \\
\hline 86 & $0.28 \pm 0.14$ & $0.51 \pm 0.26$ \\
\hline 91 & $0.44 \pm 0.30$ & $0.53 \pm 0.26$ \\
\hline 92 & $0.42 \pm 0.24$ & $0.51 \pm 0.26$ \\
\hline 93 & $0.24 \pm 0.12$ & $0.45 \pm 0.26$ \\
\hline 94 & $0.44 \pm 0.26$ & $0.53 \pm 0.26$ \\
\hline 95 & $0.29+0.16$ & $0.41 \pm 0.26$ \\
\hline 96 & $0.22 \pm 0.12$ & $0.41 \pm 0.26$ \\
\hline
\end{tabular}




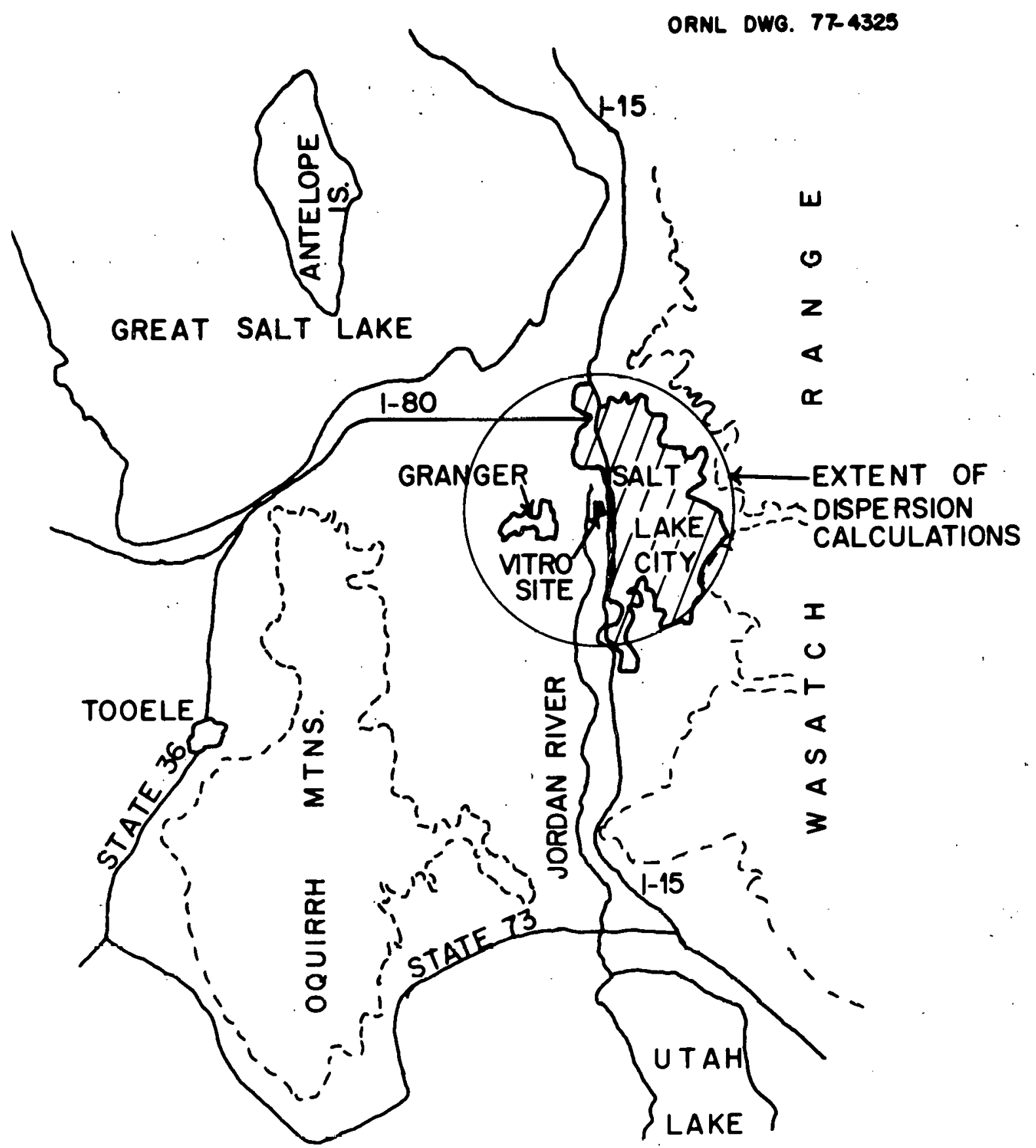

Fig. 13. Map of Salt Lake Valley showing area included in calculations of radon dispersion. 
Table 15. Average concentrations of airborne radionuclides at Suburban Sewage Treatment Plant, Salt Lake City, Utah

\begin{tabular}{|c|c|c|c|}
\hline Radionuclide & $\begin{array}{l}A v_{(p \operatorname{conc}}{ }^{d} \\
\left(p \mathrm{C}^{3}\right)\end{array}$ & $\begin{array}{l}\mathrm{MPC}_{a}^{\mathrm{bc}} \\
\left(\mathrm{pC} \mathrm{i} / \mathrm{m}^{3}\right)\end{array}$ & $\begin{array}{l}\text { Av. } \\
\text { conc./MPC }\end{array}$ \\
\hline${ }^{226} \mathrm{Ra}$ & $0.0018 \pm 0.0026$ & 2. (I) & 0.001 \\
\hline${ }^{230} \mathrm{Th}$ & $0.00088 \pm 0.0012$ & $0.08(5)$ & 0.011 \\
\hline $210 \mathrm{~Pb}$ & $0.010 \pm 0.0056$ & 4. (5) & 0.003 \\
\hline $210_{\mathrm{Po}}$ & $0.061 \pm 0.166$ & 7. (I) & 0.009 \\
\hline${ }^{234} U$ & $0.00022 \pm 0.00012$ & 4. (I) & 0.00006 \\
\hline $235 U$ & $0.000025 \pm 0.000024$ & 4. (I) & 0.000006 \\
\hline $238 \mathrm{U}$ & $0.00020 \pm 0.00014$ & 3. $(S)$ & 0.00007 \\
\hline${ }^{232} \mathrm{Th}$ & 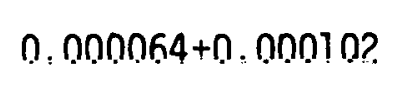 & $1 . \quad(S, I)$ & ก. กกฺกา \\
\hline \multirow[t]{2}{*}{$228 \mathrm{Ra}$} & \pm 0.002 & 1. (I) & $\underline{0.002}$ \\
\hline & & $\Sigma \mathrm{C} / \mathrm{MPC}_{\mathrm{i}}$ & 0.026 \\
\hline${ }^{222}{ }_{R n}(26)$ & \pm 1400 & $3000 \quad(s)$ & $1.4 \pm 0.5$ \\
\hline
\end{tabular}

\footnotetext{
${ }^{\mathrm{a}}$ Ref. 35.

${ }^{b}$ The most restrictive $M P C_{a}$ is given; $S=$ Soluble, $I=$ Insoluble. CRef. 37.
} 
occur $1.3 \%$ of the time. These higher velocity winds suspend particulate activity much more effectively than low velocity winds. Almost $80 \%$ of $>18$ mph winds blow toward N, NNW, or NNE directions. Thus, samples collected at this location should be representative of airborne activity concentrations attributable to the tailings pile.

The total average annual airborne activity is less than $3 \%$ of the $M P C_{a}$ as is shown in Table 15. This activity may be compared with the measured ${ }^{222} \mathrm{Rn}$ concentration ${ }^{(26)}$ and its error shown in Table 15. The contribution of airborne activity is far less than the error of the radon activity. Furthermore, application of the criteria contained in the Note to Appendix $B, 10$ CFR $20,{ }^{(36)}$ reveals that all airborne activity except ${ }^{222} \mathrm{Rn}$ may be administratively considered as "not present." All of these measurements were made in a non-habitable location. Atmospheric dispersion of the airborne activity would further reduce the concentrations of radionuclides involved. 


\section{HEALTH EFFECTS ATTRIBUTABLE TO THE VITRO TAILINGS PILE}

The results of this investigation may be used to estimate potential health effects resulting from the Vitro tailings pile. This chapter presents the methods used for calculating health effects and the results obtained.

\section{Radon Diffusion Pathway}

Maximum exposure to ${ }^{222} \mathrm{Rn}$ progeny will occur in poorly ventilated structures. For purposes of these calculations, we assume one air cxchange per hour $(59)$ and that the rate of molecular diffusiun of radun from outside air into a structure is insignificant compared to that from ventilation. Radon in the outside air arising from the tailings pile is assumed to enter a structure at the rate of $C_{0} \lambda_{v}(p C i / l i t e r-s e c)$, where $C_{0}$ is the outside radon concentration and $\lambda_{v}$ is the ventilation rate. Radon inside the structure is removed by ventilation and decay; so that the concentration is decreased at a rate of $C_{i}\left(\lambda_{v}+\lambda_{R}\right)$ (pCi/liter-sec), where $\lambda_{R}$ is the radiological decay rate and $c_{i}$ is the concentration of radon inside the structure. Over a long period of time, equilibrium will be established such that

$$
c_{0} \dot{\lambda}_{v}=C_{i}\left(\lambda_{v}+\lambda_{R}\right)
$$

since $\lambda_{v}>>\lambda_{R}$

$$
c_{0} \approx c_{i}
$$

Thus the indoor concentration of ${ }^{22} \mathrm{Rn}$ attributable to the tailings pile will approach the annual average outdoor ${ }^{222} \mathrm{Rn}$ concentration resulting from atmospheric dispersion. 
Concentrations of airborne ${ }^{222} \mathrm{Rn}$ progeny can be calculated using formulas relating these values to ventilation rate. ${ }^{(60)}$ For a ventilation rate of $1 \mathrm{hr}^{-1}$, an indoor concentration of $1 \mathrm{pCi} / 1$ iter of ${ }^{222} \mathrm{Rn}$ will produce $0.005 \mathrm{WL}$ of progeny and continuous exposure will result in an annual exposure of 0.25 WLM. Therefore, we will assume that an outdoor concentration of $1 \mathrm{pCi} / 1$ iter ${ }^{222} \mathrm{Rn}$ attributable to the tailings pile will result in an annual exposure of 0.25 WLM inside a structure.

Annual average ${ }^{222} \mathrm{Rn}$ progeny exposures may be calculated at each point listed in Table 13 by multiplying the values in this table by 0.25. Thus, maximum exposure of $1.1 \mathrm{WLM} /$ year would occur inside a structure at the north-northwest edge of the tailings pile. In contrast, the lower limit of the Surgeon General's Action Guide, $0.01 \mathrm{WL}$, would result in an annual exposure of 0.5 WLM using the continuous occupancy assumptions. Furthermore, an annual outdoor exposure at this point would be about 0.1 WLM. This value is based on average wind speed in the NNW direction, distance from the center of the pile, time of transport from source to receptor, and rate of growth of radon decay products during transport. The resulting value of $0.1 \mathrm{WLM}$ is for continuous exposure at an outside working level concentration of $0.002 \mathrm{WL}$.

A summary of estimated indoor exposures to ${ }^{222} R$ progeny attributable to the Vitro taflings pile is given in Table 16. Population exposures were calculated for each of the 16 compass directions within each radial sector and summed to provide the estimate for that radial sector. Thus, total population exposure of 2000 person-WLM/year represents a best estimate obtainable. It is only in the first sector (up 
Table 16. Summary of 222 Rn progeny exposures attributable to Vitro tailings pile

\begin{tabular}{|c|c|c|c|c|c|}
\hline $\begin{array}{l}\text { Distance from } \\
\text { center of } \\
\text { tailings pile } \\
\text { (miles) }\end{array}$ & $\begin{array}{l}\text { Maximum anriual } \\
\text { average exposure } \\
\text { (WLM/year) }\end{array}$ & $\begin{array}{l}\text { Mïnimum annua } \\
\text { Everage exposure } \\
\text { (WLM/year) }\end{array}$ & $\begin{array}{c}\text { Average innual } \\
\text { exposure } \\
\text { (WLM/year) }\end{array}$ & Populationd & $\begin{array}{l}\text { Population exposure } \\
\text { (person-WLM/year) }\end{array}$ \\
\hline $0-7$ & & & 0.0061 & 398,513 & 1,999 \\
\hline Background $f$ & & & $0.095 \pm 0.065$ & 398,513 & $38,000 \pm 26,000$ \\
\hline
\end{tabular}

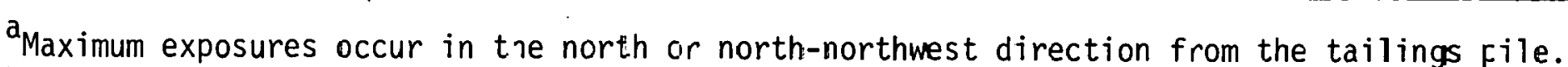

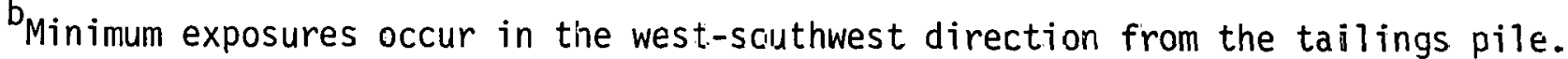

Average of all directions.

d Ref. 61 .

${ }^{e}$ obtained for each direction anc summed for each distance from tailings pile. This may not be equivalent to the product of third and =ourth columns because of population distribution.

${ }^{f}$ Calculated from average of $0.38 \mathrm{pCi} / 1$ iter with standard deviation $0=0.26 \mathrm{pCi} / 1$ iten as reported in ref. 26 . 
to $0.75 \mathrm{mile}$ from the edge of the pile) that annual average exposure exceeds the error associated with exposure due to background ${ }^{222} \mathrm{Rn}$ levels. Exposure summaries for two separate population projections ${ }^{(4)}$ are shown in Tables 17 and 18. These exposures considered a maximum, uniform population distribution for medium (12,000 persons/sq mile) and high ( 20,000 persons/sq mile) density urban growth. In these two exposure projections, it was assumed that the only remedial action was prohibition of public access to the tailings area.

Health effects attributable to these ${ }^{222} \mathrm{Rn}$ progeny exposures were estimated using data provided in the BEIR Report. ${ }^{(62,63)}$ An absolute risk estimator for death due to lung cancer was derived on the basis of a lifetime duration of risk. The footnote of Table 3-2 of the BEIR Report ${ }^{(63)}$ indicates that lung cancer accounts for $26 \%$ of the absolute risk of " 5 deaths $/ 10^{6} /$ year $/ \mathrm{rem}$ " for those over age 9 in the population. It was assumed that this ratio of 0.26 was also valid for individuals aged 0 to 9 years. Table 3-1 of the BEIR Report shows that all cancers account for 1410 deaths among persons in a population of $198 \times 10^{6}$ exposed to 0.1 rem/year at all times after birth. Deaths from in-utero exposure were not included in our estimate because the short half-lives of ${ }^{222} \mathrm{Rn}$ progeny, the low penetrating power of alpha particles and the exposure route of inhalation preclude any significant in-utero exposure to airborne ${ }^{222} \mathrm{Rn}$ progeny. Lung cancer death risk is estimated as $0.26 \times 1410 \div 197.9 \div 0.1$, or 18 deaths/year in a population of $10^{6}$ exposed to 1 rem/year postpartum. 
Table 17. Extrapolated ${ }^{222} \mathrm{Rn}$ exposures attributable to Vitro tailings pile for medium density population projection

\begin{tabular}{crc}
\hline Sector & Population $^{\text {a }}$ & $\begin{array}{c}\text { Population cxposurc } \\
\text { (person-WLM/year) }\end{array}$ \\
\hline $0-1$ & 40,000 & 6,000 \\
$1-2$ & 110,000 & 2,750 \\
$2-3$ & 190,000 & 1,860 \\
$3-4$ & 260,000 & 1,460 \\
$4-5$ & 340,000 & 1,260 \\
$5-6$ & 420,000 & 1,130 \\
$6-7$ & 490,000 & 1,030 \\
$0-7$ & $1,850,000$ & 15,500 \\
& & $176,000 \pm 120,000$ \\
\hline
\end{tabular}

a Ref. 4 . 
Table 18. Extrapolated 222Rn exposures attributable to Vitro tailings pile for high density population projection

\begin{tabular}{crc}
\hline $\begin{array}{c}\text { Distance } \\
(\text { miles })\end{array}$ & Population & $\begin{array}{c}\text { Population exposures } \\
\text { (person-WLM/year) }\end{array}$ \\
\hline $0-1$ & 60,000 & 9,000 \\
$1-2$ & 180,000 & 4,500 \\
$2-3$ & 310,000 & 3,000 \\
$3-4$ & 430,000 & 2,400 \\
$4-5$ & 550,000 & 2,000 \\
$5-6$ & 670,000 & 1,800 \\
$6-7$ & 800,000 & 1,700 \\
$0-7$ & $3,000,000$ & 24,400 \\
Background & & $285,000 \pm 195,000$ \\
\hline
\end{tabular}

${ }^{a} \operatorname{Ref.} 4$. 
The authors of the BEIR Report considered inherent inadequacies in estimating absorbed dose in rads from a given exposure in WLM and made the following statement (p. 148):

"On the basis of the present evidence, $1 \mathrm{rad} / \mathrm{WLM}$ is probably close to the upper limit for a reasonably uniform dose to the basal cell layer of the epithelium of the larger bronchi on a probabilistic basis. In the presence of existing chronic bronchitis, the dose factor may well be substantially lower, owing to increased thickness of the mucous layer as well as of the epithelium, and thus a figure of $0.5 \mathrm{rad} / W \mathrm{LM}$ has been adopted for this report. It should be emphasized that uncertainties in this value are probably greater than for the working level measurements themselves in determining risks per rad for the mining populations."

On the basis of this discussion, we estimated that an exposure of $1 \mathrm{WLM} /$ year could be considered, in a very conservative manner, to result in a lung dose of $10 \mathrm{rems} /$ year to members of the general population. Thus, continuous exposure to 1 WLM/year will result in approximately. 180 deaths per year per $10^{6}$ persons exposed under these conditions. The reader should realize that the absolute risk estimator was obtained from epidemiological studies of uranium and other mineral miners, many of whom were cigarette smokers. Thus, the risk estimator is not precise and should not be regarded as an absolute number.

Health effects which we postulate as attributable to the Vitro tailings pile are given in Table 19. These were calculated from exposures given in Tables 16, 17, and 18. Health effects which may be attributable to background ${ }^{222}$ Rn progeny levels are shown in Table 19 for comparison. It may be noted that in every case effects due to the tailings pile are about 10\% of the standard deviation associated with the background estimate. 
Table 19. A comparison of potential health effects attributable to ${ }^{22} \mathrm{Rn}$ progeny exposure from the Vitro tailings pile and from background from the population residing continuously within 7 miles of the Vitro tailings pile

\begin{tabular}{ccc}
$\begin{array}{c}\text { Population } \\
\text { Lung cancer deaths/year in the population } \\
\text { attributable to: } \\
\text { Vitro tailings } \\
\text { pile }\end{array}$ & $\begin{array}{c}\text { Background } \\
(0.38 \pm 0.26 \mathrm{pCi} / 1 \text { iter })\end{array}$ \\
\hline Present $(400,000)$ & 0.4 & $7 \pm 5$ \\
Extrapolated $(1,850,000)$ & 3. & $32 \pm 22$ \\
Extrapolated $(3,000,000)$ & 4. & $51 \pm 35$ \\
\hline
\end{tabular}

$a_{\text {Ref. }} 26$. 


\section{Exposure to Gamma Radiation}

The plot of gamma exposure as a function of distance from the Vitro pile given in Fig. 12 was used to estimate the annual exposure shown in Table 20. In the preparation of this table, it was assumed that $1 R$ in air is equivalent to 1 rem in tissue. An absolute risk estimator for death from all cancers, including leukemia, as given in Table 3- $l$ of the BEIR Report was equated to 101 deaths per year for a continuous radiation dose equivalent of $1 \mathrm{rem} /$ year to a population of $10^{6}$.

An average background terrestrial gamma exposure of $8 \pm 2 \mu R / h r$. was measured at the sampling locations shown in Fig. 8. Although net gamma exposures attributable to the Vitro tailing pile could not be measured or interpolated accurately beyond 2 miles, a population exposure to 7 miles was conservatively estimated to be 500 person-rem/year.

Potential health effects due to pile gamma rays were estimated for the present population distribution. It was assumed that individuals in the population were subject. t. continuous outdoor exposure lu gamma rays. This results in a conservative estimate but represents, at the most, about $10 \%$ of the potential effects due to radon diffusion. However, the estimate of effects due to radon progeny assumed continuous indoor exposure in a poorly ventilated strurture. Becausc the same population cannot be outdoors and indoors at the same time, the effects of gamma exposure are calculated only to provide a perspective for ${ }^{222} \mathrm{Rn}$ exposure and should not be construed as being additive to the potential effects due to exposure to ${ }^{222} \mathrm{Rn}$ daughters. 
Table 20. Potential health effects attributable to external gamma irradiation resulting from the Vitro tailings pile

\begin{tabular}{|c|c|c|c|c|}
\hline Sector & $\begin{array}{l}\text { Exposure } \\
(\mu R / h r)\end{array}$ & $\begin{array}{l}\text { Exposure } \\
\text { (mR/year) }\end{array}$ & $\begin{array}{r}\text { Population exposure } \\
\text { (person-rem/year) }\end{array}$ & $\begin{array}{c}\text { Effects } \\
\text { (deaths/year) }\end{array}$ \\
\hline $0-1$ & 12 & 105 & 160 & \\
\hline $1-2$ & 1 & 9 & 180 & \\
\hline $2-3$ & $<1$ & & & \\
\hline $0-7$ & & & 500 & 0.05 \\
\hline Background & $8 \pm 2$ & $70 \pm 17$ & $28,000 \pm 7,000$ & $2.8 \pm 0.7$ \\
\hline
\end{tabular}


Health Effects Attributable to Other Pathways

Exposures attributable to other pathways have been considered in

Chapters 3 and 5 . Such potential exposures of the population are probably inconsequential when compared to $222 \mathrm{Rn}$ diffusion. 


\section{SUMMARY AND CONCLUSIONS}

An assessment was made of the radiological hazards associated with the inactive uranium tailings pile in Salt Lake Ci.ty, Utah. An evaluation was made of various pathways by which man is exposed to radioactivity from the tailings. Pathways considered were: 1) radon diffusion from the pile, 2) radioactivity which becomes airborne due to wind, 3 ) radioactivity which is ingested through the intake of food grown on contaminated land, 4) radioactivity which enters the body directiy or indirectiy. through aquatic paths, and 5) exposure to direct gamma radiation.

Measurements were made to determine the extent to which radioactivity had spread to areas away from the site and to evaluate existing exposure conditions. Radium contamination was found down to a depth of three feet below the tailings; however, due to the error associated with sampling techniques and the possibility of some degree of cross contamination in régions where samples of soil were collected, the actual downward migration of radium and other nuclides was probably less than indicated by radioactivity profiles. Soil samples were taken on the surface and at a depth of one foot at 60 locations outside of the perimleter of the mill property. Radioactivity had been blown or otherwise moved from the pile aut to a distance of several hundred meters (tailings have been moved for private use to distances of several miles from the site). Surface samples collected on the west side of 900 West Street had activities ranging from less than $1: 0 \mathrm{pCi} / \mathrm{g}$ to $34 \mathrm{pCi} / \mathrm{g}$, while samples at" a depth of one foot had activities ranging from about $2 \mathrm{pCi} / \mathrm{g}$ to 6.6 $\mathrm{pCi} / \mathrm{g}$. Surface samples collected on the south side of 3300: South Street 
had activities ranging from $1.3 \mathrm{pCi} / \mathrm{g}$ to $51 \mathrm{pCi} / \mathrm{g}$, while at a depth of one foot most activities ranged from 1 to $8 \mathrm{pCi} / \mathrm{g}$ but in two locations values were higher, 20 and $289 \mathrm{pCi} / \mathrm{g}$, respectively. In areas where tailings had been used in construction at the sewage treatment plant, values as high as $570 \mathrm{pCi} / \mathrm{g}$ were found.

Sediments collected in a drainage ditch which runs through the tailings area were found to contain above background levels of ${ }^{226} \mathrm{Ra}$, $238 \mathrm{U}, 230 \mathrm{Th}$, and $210 \mathrm{~Pb}$. Sediment samples taken from the Jordan River both upstream and downstream from the mouth of this drainage ditch were found to contain radionuclides at approximately background level. However, analysis of a sample collected within $100 \mathrm{~m}$ of the discharge into the Jordan River indicated that activity in the sediment was significantly less than in samples closer to the pile. The activity of this sample was on the order of three times background: Samples taken from Mill Creek, which runs along the northern boundary of the mill site, contained low levels of radionuclides. If a remedial action program is conducted at this site, consideration should be given to dredging Mill Creek and the drainage ditch and containing the spoil in order to reduce the concentration of radionuclides in the sediment of those streams.

Except for water which was collected in holes drilled through the tailings, the levels of radioactivity measured were not distinguishable from background.

Short-lived radon daughters were sampled in several structures in the vicinity of the pile. Places were chosen on the basis of 1) being close to the pile but having no tailings in intimate contact with the 
structure, 2) having been constructed over a layer of tailings,: and 3) having been constructed with tallings close to the structure but with no tailings under the floor. Results for these three situations are presented in Table 11. It should be pointed out that these radon daughter concentrations are representative of short term measurements and extrapolations to annual averages should not be attempted. One should note in Table 11 that the concentration of radon measured in a closed store room of one of the commercial buildings built over tailings (Bld. C, Fig. 11) ranged to about $550 \mathrm{pCi} / 1$ iter with daughters in approximately $42 \%$ equilibrium. In most cases, the ventilation rate of a structure is such that the level of radon in the structure will be significantly reduced for much of the year but during cold months when most structures are closed, radon concentrations should be near maximum, and the degree of equilibrium between radon and its daughters will also be maximum.

This tailings pile represents a large, steady-state source of radon... It was estimated that the radon source term is $2.6 \times 10^{8} \mathrm{pCi} / \mathrm{sec}$. In Chapter 5, a description was given of the technique used to estimate dispersion of radon through the environment. These estimates indicated that radon concentrations had decreased to $<10 \%$ of background in all. directions at 4 miles from the pile. Calculations were carried out to a distance of 7 miles from the center of the pile. Beyond this distance, concentrations of radon were less than $1 \%$ of natural background and the additional population represented only a small fraction of the total. within 7 miles. Also the diffusion model used to make these calculations loses validity when air masses reach the mountain range to the east. 
Comparisons were made of calculated values of radon concentration as a function of distance from the plle with measurements of radon at several places in the vicinity of the Vitro site. Except for one station, the averages of the calculated and measured values were well within the stated limits of error for both sets of data.

A set of airborne radioactivity measurements made over a period of one year by the EPA were examined carefully in this study. These measurements indicated that average annual airborne activities were less than $3 \%$ of maximum permissible concentrations in air $\left(M P C_{a}\right)$ and exposures due to airborne activity were less than errors associated with radon exposure. Furthermore, the presence of all airborne radionuclides except ${ }^{222} \mathrm{Rn}$ could be considered insignificant.

Exposure rates due to gamma rays from the pile were measured out to a distance of 2 miles. These measurements were used to calculate annual exposures in person-rem.

In Chapter 6, it was estimated that the annual incidence of lung cancer due to continuous exposure to the pile in its current condition was 0.4 cases per year. In addition, it was estimated that the mortality rate due to all cancers as a result of exposure to gamma rays from the pile will be 0.05 deaths per year. The health effects due to exposure to airborne activity (resuspended radionuclides) were not estimated in detail because the measured concentration of these nuclides was only $3 \%$ of the $M P C_{a}$ (at a location where ${ }^{222} \mathrm{Rn}$ greatly exceeded its $M P C_{a}$ ) and were less than the error associated with radon activity estimates. In three commercial structures bordering the tailings pile on 900 West Street, short term measurements were made of external gamma ray 
exposure rates and of the concentration of airborne radon daughters. Based on these short term measurements, and an average annual working time of 2000 hours, gamma ray exposure rates range from 15 to $400 \mathrm{mrem} / \mathrm{yr}$, and radon daughter concentrations range from 0.24 to 83 working level months (WLM). According to information presented in Chapter 6 (page 80), conservative estimates of the potential lung dose to individuals exposed to the above cumulative radon daughter concentrations are $2.4 \mathrm{rems} / \mathrm{yr}$ and $830 \mathrm{rems} / \mathrm{yr}$ respectively.

It should be stressed that during this survey, time did not permit the determination of average annual radon daughter concentrations in accordance with guidelines recommended by the U. S. Surgeon General, which serve as the basis for the Grand Junction Remedial Action Criteria (10CFR712). (64) In these criteria, "indoor radon daughter concentration level" is stated to mean "that concentration of radon daughters determined by averaging the results of six air samples each of at least 100 hours duration, and taken at a minimum of four week intervals throughout the year in a habitable area of a structure". The short term samples collected during this study should be supplemented by a series of samples taken in accordance with the method outlined in 10CFR712. Estimates of potential health effects to the working population in these commercial structures should not be made until the average annual radon daughter concentration has been determined.

Estimates of the incidence of health effects are for the tailings pile in its present condition. If the pile were stabilized in place by covering it with earth, airborne activity and terrestrial pathways might be eliminated and the radon emanation pathway would be reduced in proportion 
to the thickness of earth cover. This remedial action would not permit construction of residences on the property, and perpetual control would be necessary. Removal of the tailings would accomplish several things: 1) a large in situ source of natural radioactivity would be removed from near the center of a major metropolitan area, 2) concentrations of radon in the vicinity of the pile would be reduced to background, 3) it would be possible to release the property for productive utilization in future years without the need for continued surveillance, and 4) tailings could be moved to a permanent disposal location where the radionuclides involved would be removed from biospheric contact in a practical manner. 


\section{REFERENCES}

1. USAEC, Environmental Survey of the Uranium Fuel Cycle, WASH-1248 (April 1974).

2. USEPA, Environmental Analysis of the Uranium Fuel Cycle, Part I. Fuel Supply, PB-235804 (October 1973).

3. USEPA and USAEC, Summary Report, Phase I. Studies of Inactive Uranium Mill Sites and Tailings Piles (October 1974).

4. Ford, Bacon and Davis, Utah, Inc., Phase II - Title I Engineering Assessment of Inactive Uranium Mill Tailings - Vitro Site, Salt Lake City, Utah (April 30, 1976).

5. USEPA and USAEC, Studies of Inactive Uranium Mill Sites and Tailings Piles, Salt Lake City, Utah, Phase I Report (October 1974).

6. F. Gera, Geochemical Behavior of Long-Lived Radioactive Wastes, ORNL-TM-4481 (July 1975).

7. J. W. Healy, A proposed Interim Standard for Plutonium in Soils, LA-5483-MS (January 1974).

8. A. W. Klement, Jr., et al., Estimates of Ionizing Radiation Doses in the United States 1960-2000, USEPA ORP/CSD 72-1 (August 1972).

9. M. B. Sears, et al., Correlation of Radioactive Waste Treatment Costs and the Environmental Impact of Waste Effluents in the Nuclear Fuel Cycle for Use in Establishing "As-Low-As-Practicable" Guides Milling of Uranium Ores, ORNL-TM-4903, Vol. 1 (May 1975).

10. M. V. J. Culot, H. G. 01son, and K. J. Schiager, Radon Progeny Control in Buildings, C00-2273-1, Colorado State University, Fort Collins, Co. (May 1973). 
11. T. I. Sisigina, "Assessment of Radon Emanation from the Surface of Extensive Territories," pp. 239-244 in Nuclear Meteorology, ed. by K. P. Makhon'ko and S. G. Malakhow, Gidrometeoizdat, Moscow, 1972 , TT-74-50011.

12. K. Megumi and T. Mamuro, J. Geophys. Res. 79, 3357-60 (1974).

13. W. E. Clements and M. H. Wilkening, J. Geophys. Res. 79, 5025-9 (1974).

14. D. Guedalla et a1., J. Geophys. Res. 75. 357-69 (1970).

15. H. W. Kramer, G. L. Schroeder, and R. D. Evans, "Measurement of the Effects of Atmospheric Variables on Radon-222 Flux and Soil-Gas Concentrations," pp. 191-215 in Natural Radiation Environment, ed. by J. A. S. Adams and W. M. Louder, The University of Chicago Press, Chicago, 1964.

16. W. M. Cox, R. L. Blanchard, and B. Kahn, "Relation of Radon Concentration in the Atmosphere to Total Moisture Retention in Soil and Atmospheric Thermal Stability." $\mathrm{PP}$. 436-46 in Radionuclides in the Environment, Am, Chem. Soc., Washington, 1970.

17. L. D. Baver, Soil Physics, 3rd ed., p. 214, Wiley, New York, 1965.

18. A. B. lanner, "Radon Migration in the Ground: A Review," pp. 161= 190 in The Natural Radiation Environment, ed. by J. A. S. Adams and W. M. Louder, The University of Chicago Press, Chicago, 1964.

19. G. L. Schroeder, H. W. Kramer, and R. D. Evans, "Diffusion of Radon in Several Naturally Occurring Soil Types," J. Geophys. Res. 70, $471-4(1965)$.

20. F. A. Gifford, Director, Atmospheric Turbulence Diffusion Lab, NOAA, private communication, January 19, 1976. 
21. W. M. Culkowski and M. R. Patterson, A Comprehensive Atmospheric Transport and Diffusion Model, ORNL-NSF-EATC-17, 1976.

22. F. A. Gifford, Atmospheric Dispersion Models for Environmental Pollution Applications, ATDL Contribution File No. $75 / 7$ (June 1975).

23. R. N. Snelling, Radiat. Data Rep. 12, 17-28 (1971).

24. R. N. Snelling, Radiat. Data Rep. 11, 511-7 (1970).

25. R. N. Snelling and S. D. Shearer, Jr., Radiat. Data Rep. 10, 475-87 (1969).

26. S. D. Shearer, Jr., and C. W. Sill, Health Phys. 17, 77-88 (1969).

27. W. A. Goldsmith and F. F. Haywood, Radon Lung Dosimetry: Exposure Conditions - A Survey of the Literature, ORNL/TM-5286, in preparation.

28. Federal Radiation Counci1, Guidance for the Control of Radiation Hazards in Uranium Mining, Staff Report No. 8, Revised (Sept. 1967).

29. R. D. Evans, Health Phys. 17, 229-52 (1969).

30. H. M. Parker, Health Phys. 16, 553-61 (1969).

31. L. R. Anspaugh et al., Health Phys. 29, 571-82 (1975).

32. M. T. Mills, R. C. Dahlman, and J. S. 01son, Ground Level Air . Concentrations of Dust Particles Downwind from a Tailings Area During a Typical Windstorm, ORNL/TM-4375 (Sept. 1974).

33. A. J. Breslin and H. Glauberman, "Investigations of Radioactive Dust Dispersed from Uranium Tailings Piles," pp. 249-53 in Environmental Surveillance in the Vicinity of Nuclear Facilities, ed. by W. C. Reinig, Charles C. Thomas, Springfield, I11., 1970.

34. H. Glauberman and A. J. Breslin, Uranium Mill Tailings Study, HASLTM-64-14 (July 31, 1964).

35. D. W. Hendricks, USEPA, Las Vegas, Nevada, Private communication, June 26, 1975. 
36. 10 CFR 20, Standards for Protection Against Radiation (April 30, 1975).

37. Federal Radiation Council, Background Materlal for the Development of Radiation Protection Standards, Report No. 2 (September 1961).

38. D. Lambdin and L. J. Dymersbi, Progress Report on Uranium Mill Tailings Study, Phase II, U. S. Public Health Service (November 1965).

39. S. D. Shearer, Jr. and G. F. Lee, Health Phys. 10, 217-28 (1964).

40. B. Havlik, J. Grafova, and B. Nycova, Health Phys. 14, 417-22 (1968).

41. B. Havlik, B. Nycova, and J. Grafova, Heal th Phys, 14,..423-30 (1968)..

42. M. H. Feldman, Summary Report 1959-1961, Winchester Laboratory, Topical Report WIN-125 (September 30, 1961).

43. D. E. McCurdy et al., "Evaluation of Plutonium-Contaminated Radioactive Waste Disposal Areas with Respect to their Potential Hazard and Eventual Disposition,". in Quarterly Report-Transuranic Solid Waste Management Research Programs, Oct.-Dec., 1973, LA-5614-PR (May 1974):

44. J. H. Thorngate and J. E. Parks, Health Phys. 12, 385-393 (1965).

45. J. F. Emery, F. F. Dyer, "Multi-Element Determination in Environmental Neutron Activation Anaiysis Using MONSTR", Proccedings of the Second International Conference on Nuclear Methods and Environmental Research, CONF-740701, held at the University of Missouri, Columbia, Mo., July 29-31, 1974.

46. E. B. Wagner and G. S. Hurst, Health Phys. $\underline{5}, 20-26$ (1960).

47. J. H. Thorngate et a1., "Response of a Neutron-Insensitive GammaRay Dosimeter as a Function of Photon Energy," Dosimetry Research, ORNL-3697 (Ju1y 31, 1964). 
48. P. T. Perdue, W. H. Shinpaugh, J. H. Thorngate, and J. A. Auxier, Hea th Phys. 26, 114-6 (1973).

49. G. D. Kerr et al., "Measurements of Radon Daughter Concentrations in Air," pp. 202-7 in Dosimetry for Human Exposures and Radiological Impact, ORNL-4979 (July 31, 1974).

50. J. A. Auxier, W. H. Shinpaugh, J. H. Thorngate, and P. T. Perdue, "Determination of Radon in Air," Patent \#3,805,070 (April 16, 1974).

51. G. D. Kerr, Measurement of Radon Progeny Concentrations in Air by. Alpha-Particle Spectrometry, ORNL/TM-4924 (July 1975).

52. L. R. Anspaugh, private communication, 1975.

53. L. R. Anspaugh et al., "The in-situ Measurement of Radionuclides in the Environment with a Ge(Li) Spectrometer," pp. 279-303 in The Natural Radiation Environment II, CONF-720805-P1 (August 7-11, 1972).

54. R, C. Pendleton, private communication, 1975.

55. A. B. Tanner, "Physical and Chemical Controls in Distribution of Radium-226 and Radon-222 in Ground Water Near Great Salt Lake, Utah," pp. 253-76 in The Natural Radiation Environment, The University of Chicago Press, Chicago, 1964.

56. K. J. Schiager, Radiat. Data Rep. 15, 411-25 (1974).

57. D. E. Bernhardt, F. B. Johns, and R. F. Kaufmann, Radon Exhalation from Uranium Mill Tailings Piles, Techn. Note ORP/LV-75-7(A), November 1975. 
58. U. S. Department of Commerce, NOAA, Environmental Data Service, Seasonal and Combined Wind Distribution by Pasquill Stability Classes (STAR Program), Salt Lake City, Utah, Jan. 1970-Dec. 1972, Job No. 0177.2, National Climatic Center, Asheville, N. C., August 9, 1973.

59. T. H. Handley and C. J. Barton, Home Ventilation Rates: A Literature Survey, ORNL-TM-4318 (1973).

60. A. K. M. M. Haque and A. J. L. Collinson, Health Phys. 13, 431-43 (1967).

61. P. R. Coleman, Energy Division, ORNL, Private communication of population distribution about Vitro tailings pile based on 1970 U. S. Census, November 1975.

62. BEIR Report, The Effects on Populations of Exposure to Low Levels of Ionizing Radiation, pp. 145-56, NAS/NRC (November 1972).

63. BEIR Report, The Effects on Populations of Exposure to Low Levels of Iorilizing Radiation, pp. 167-73, NAS/NRC (November 1972).

64. Grand Junction Remedial Action Criteria, 10CFR; Part 712, Federal Register, Vo1. 41, No. 252, Thursday, December 30, 1976. 
ORNL/TM-5251

Dist. Category UC-41

INTERNAL DISTRIBUTION

1-2. Central Research Library

3. Document Reference Section

4-5. Laboratory Records

6. Laboratory Records, ORNL, R.C.

7. ORNL Patent Office

8. J. A. Auxier

9. R. E. Blanco

10. R. L. Clark.

11. W. D. Cottrell

12. K. E. Cowser

13. F. L. Culler

14. D. M. Davis

15. H. W. Dickson

16-18. W. A. Goldsmith

19-30. F. F. Haywood

31. R. F. Hibbs

32. F. J. Hurst

33-34. D. G. Jacobs
35. S. V. Kaye

36. G. D. Kerr

37. R. W. Leggett

38. P. M. Lantz

39. T. W. Oakes

40. P. T. Perdue

41. H. Postma

42. C. R. Richmond

43. P. S. Rohwer.

44. A. D: Ryan

45. M. . T. Ryan

46. M. B. Sears

47. J. E. Turner

48. E. B. Wagner

49. P. J. Walsh

50-60. File - Technology

Assessments

\section{EXTERNAL DISTRIBUTION}

61. Safety and Environmental Control Division, DOE-ORO

62. Research and Technical Support Division, DOE-ORO

63-64. Chief, Central Mail and Files, NRC-Washington

65. L. Joe Deal, DOE-Washington

66-75. R. H. Kennedy, DOE-Washington

76-78. J. G. Themel is, DOE-Grand Junction, CO 81501

79-81. Jay Silhanek, EPA, Waterside Mall (East Tower), Washington, DC 20460

82. L. E. Link, ANL, 9700 South Cass Avenue, Argonne, IL 60439

83. A. J. Breslin, HASL, 376 Hudson Street, New York, NY 10014

84-87. Vern Rogers, Ford, Bacon \& Davis Utah, Inc., P.0. Box 8009, Salt Lake City, UT 84108

88. L. J. 01son, Director of Health, State of Utah, 44 Medical Drive, Salt Lake City, UT 84113

89. Dennis Dalley, Utah State Division of Health, 72 East 4 th South, Salt Lake City, UT 84111

90. Harry Gibbons, County Health Officer, 610 South 200 East, Salt Lake City, UT 84111

91. D. W. Hendricks, EPA, P. 0. Box 15207, Las Vegas NV 89121

92. A. J. Hazle, Colorado Department of Health, 4210 East 11 th Avenue, Denver, CO 80220

93-94. R. E. Turley, State of Utah, 3008 MEB, University of Utah, Salt Lake City, UT 84112 
95. Robert C. Pendleton, Radiation Safety Office, University of Utah, Salt Lake City, UT 84112

96. C. E. Roessler, Department of Environmental Engineering Sciences, University of Florida, Gainesville, FL 32611

97. R. G. Beverly, Union Carbide Corporation, P. 0. Box 1049, Grand Junction, CO 81501

98. K. Z. Morgan, School of Nuclear Engineering, Georgia Institute of Technology, Atlanta, GA 30332

99. R. D. Evans, 4621 E. Crystal Lane, Scottsdale; AZ 85353

100. C. W. Sil1, D0E-100, Idaho Falls, ID 83401

101. S. D. Shearer, EPA, Washington, DC 20460

102. J. E. Jobst, EG\&G, Inc., 680 E. Sunset Drive, Las Vegas, NV 89101

103. Z. G. Burson, EG\&G, Inc., 680 E. Sunset Drive, Las Vegas, NV 09101

104. P. J. Magno; Mail Stop 396\$S, U. S. Nuclear Regulatory Commission, Washington, DC 20555

105. G. Cowper, Head, Health Physics Branch, Chalk River Nuclear" Laboratories, Chalk River, Ontario, Canada

106-117. W. E. Mott, Director, Division of Environmental Control Technology, Germantown, Md. 20767

118. J. L. Liverman, Director Division of Biomedical and Environmental Research, Washington, D.C. 20545

119-369. Given distribution as shown in TID-4500 under Health and Safety category UC-41 (25 copies - NTIS) 